\begin{tabular}{|c|}
\hline نضال "محمد فتحي"، الشمالي \\
\hline أستاذ مشارك \\
\hline قسم اللغة العربية \\
\hline كلية الأميرة عالية الجامعية \\
\hline جامعة البلقاء التطبيقية \\
\hline الأردن \\
\hline
\end{tabular}

nidalshamali@gmail.com 


\section{تمثيلات الأكورة وانعكاساتها في خطاب بلرية البشر القصصي \\ نضال "محمد فتحي"، الشمالي}

مستخلص

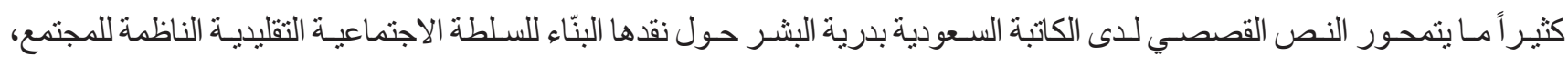

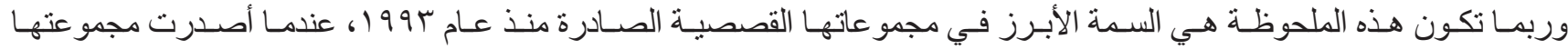

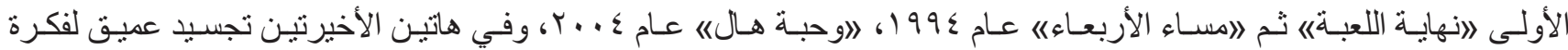
الدر اسة.

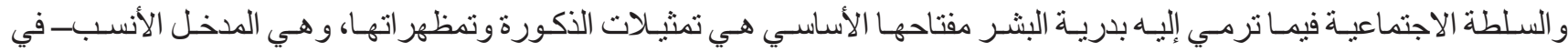

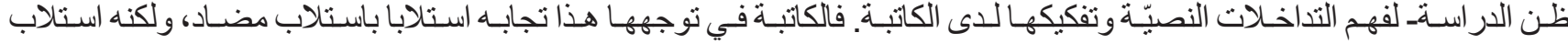
كتابي للنكورة في خطابها القصصسي المتخيّل.

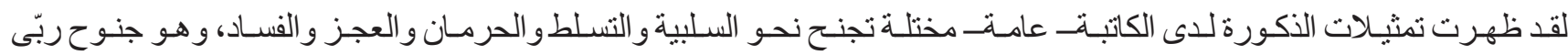

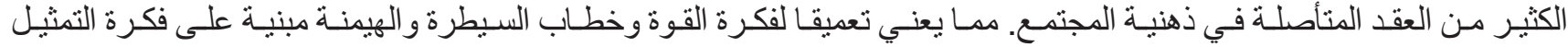

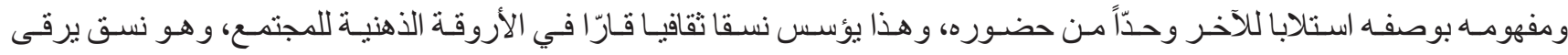

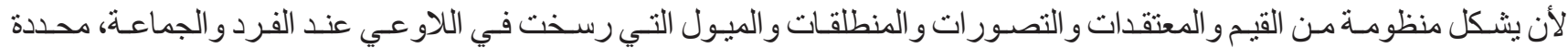

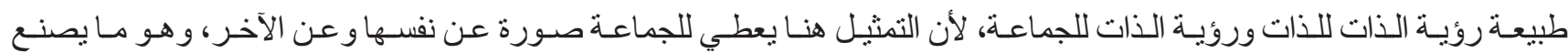

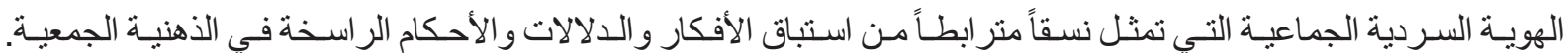

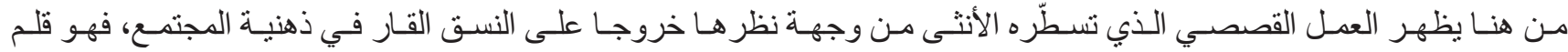

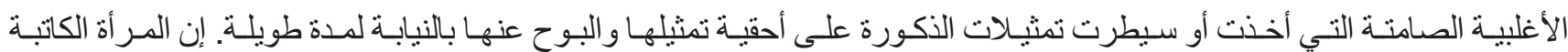

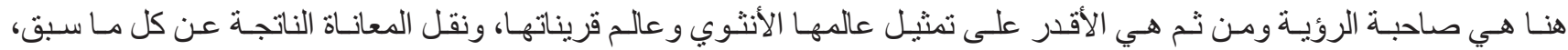

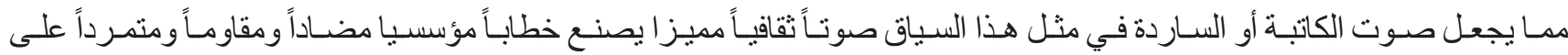
السباقات الأخرى المسبطرة.

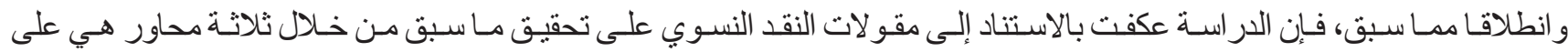

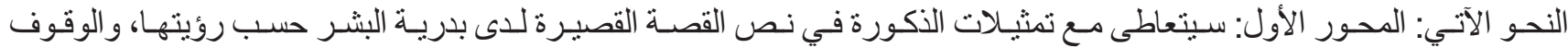

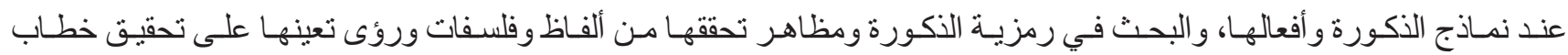

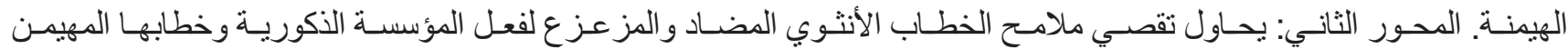

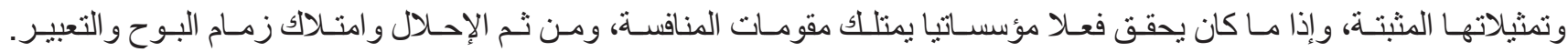

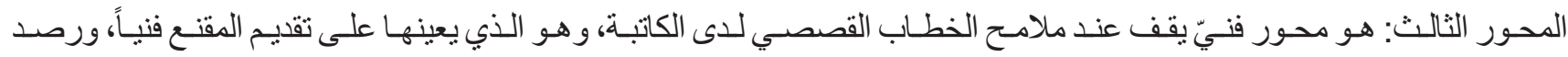

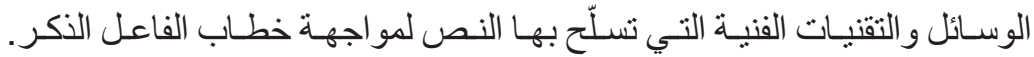




\title{
The Representation of Masculinity and its Reflections in the Short Narrative Discourse of Badriya Al-Beshr
}

\author{
Nidal Al-Shamali
}

\begin{abstract}
The short stories of the Saudi writer Badriya Al-Beshr focus on her constructive criticism of conventional social power that governs society. This is actually the most obvious feature of her short story collection that was published in 1993 and the other two collections, "Wednesday Evening" (1994) and "Cardamom" (2004).

Social power, as Badriya Al-Beshr shows, is best demonstrated in different representations of masculinity which the researcher believes to be the key to understand intertextuality of the text and its deconstructive features. In this context, Al-Beshr faces usurpation by a counter usurpation; a usurpation through writing fiction which deprives her imaginative narrative of the usual masculine discourse.
\end{abstract}

The writer has represented masculinity as a general, distorted, feature that resorts towards negative attitudes, absolute control, deprivation, disability and corruption. This extremity resulted in much complexity that is deeply rooted in the social mentality. This has deepened the ideas of absolute power and controlling discourse which are based on the concept of masculine representation as a usurpation of the other and a limiting of its presence. These ideas and the concepts they have produced have indeed generated a stable cultural pattern in the social mentality; a pattern that has developed a system of values, beliefs, visions and tendencies which are deeply rooted in the subconscious of the individual and social groups. This stable cultural pattern has specified the way the individual views himself and other social groups. This is due to the fact that representations of masculinity provide the social group with an image of itself and of the other. This, in turn, forms the collective narrative identity which represents a coherent system of pre-thinking, indications or signs and rules that are all deeply rooted in the collective mentality of the specified social group.

Here comes the role of the female writer who introduces her own point of view as she deviates from the usual pattern that is so much rooted in the mentality of her society. In this respect, Al-Beshr's short stories represent the voice of the silent subaltern that has long been controlled by masculine representations and deprived of its right to represent its feminine voice. The masculine voice has long spoken for the feminine silent voice. The female writer here is the one who introduces a genuine vision that best depicts her world and that of all women like herself. This voice faithfully represents the suffering of the silent subaltern, consequently, it has become a distinguished cultural voice that forms a counter and a rebellious discourse resisting all the other dominating contexts.

This paper applies feminist criticism to discuss the previous ideas through three different dimensions. The first dimension discusses the representations of masculinity in the short stories of Badriya Al-Beshr, its symbols and the vocabulary, philosophy and visions which she uses to depict the dominating masculine discourse. The second dimension traces the general features of the counter feminine discourse that shakes the stable masculine institution, its discourse and deeply rooted images. The researcher will show to what extent this feminine discourse can form an independent active institution that competes with the masculine one and whether it would be able to replace it and speak for itself. The third dimension is a stylistic one that shall discuss the features of Al-Beshr's narrative discourse and how persuasive it may be. In addition, the researcher focuses on the means and stylistic techniques used by the writer to face the dominating masculine discourse.

Keywords: Representation, Short Story, Badriya Al-Beshr. 


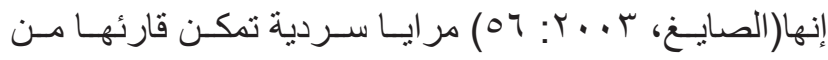

رصد ملامسح (الأنـا) وتفاصيـل عالمها وطبيعـة طقوسـها إبـان

$$
\text { اغتر ابهـا عـن (الآخـر ). }
$$

إنّ الكتابـة النسـوية اليـوم تتبنّـى أكثـر مـن أيّّ وقـت مضـى

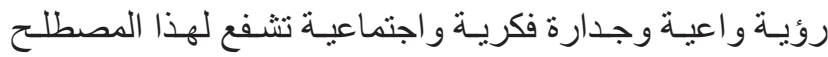

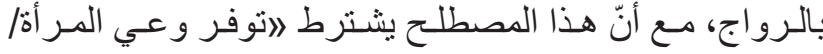

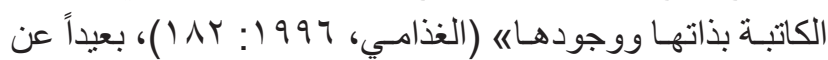

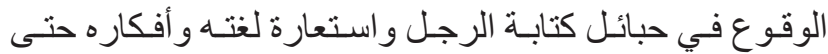

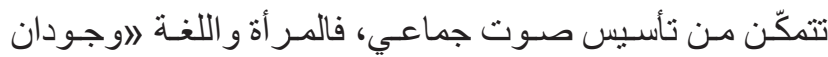

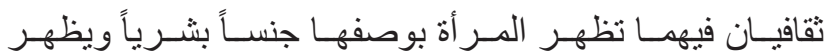

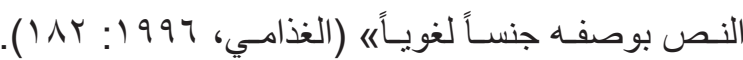

وبمـا أنّ الجهد كلـه ينصـبّ في خانـة الفنـون و الآداب و الفلسفة

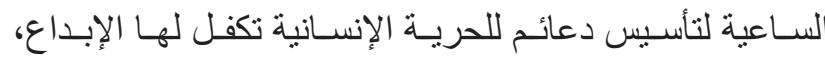

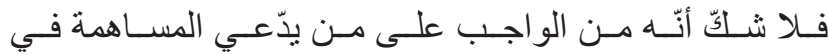

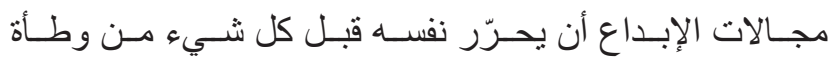

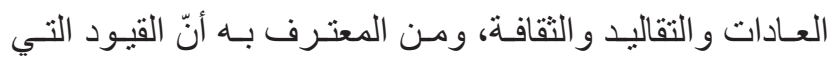

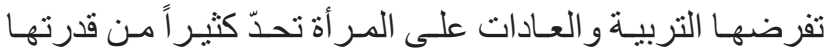

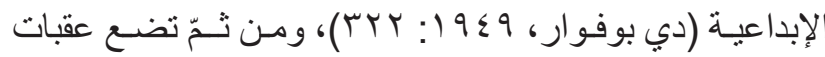

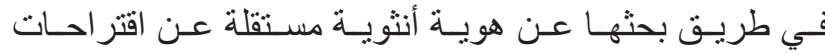

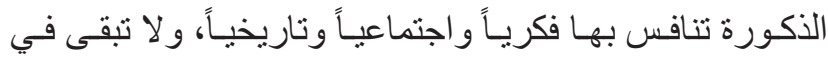
نطـاق التبعيـة و التفكيـر النمطي وتسيِّّ النسـق الثقافي.

\section{هدف الاراسة ومنهجيتها}

تهـدف هـذه الدراســة فيمـا تهـدف إليسها إلـى كثـف تمثيـلات

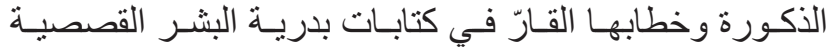

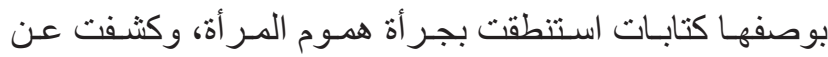

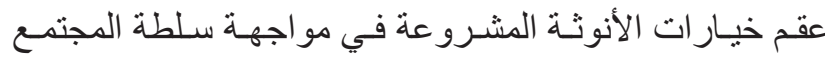

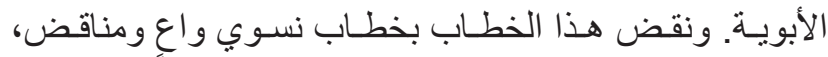

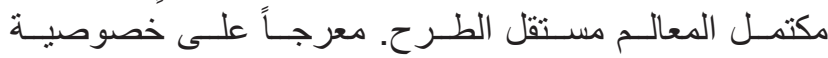

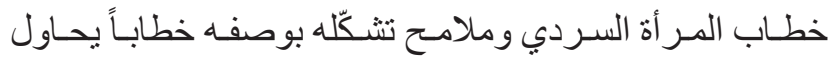

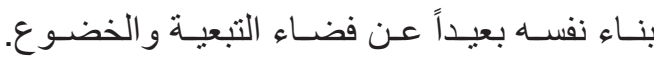

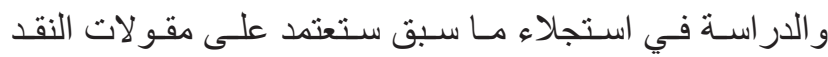

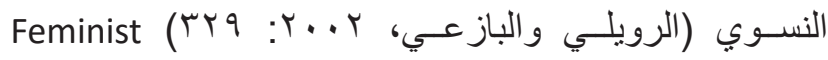

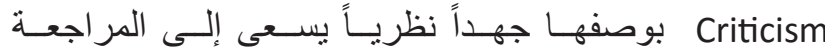

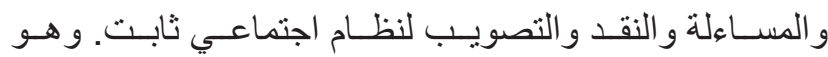

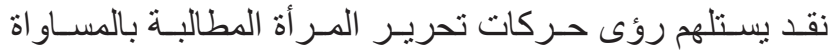

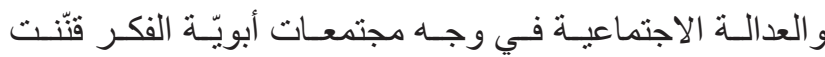

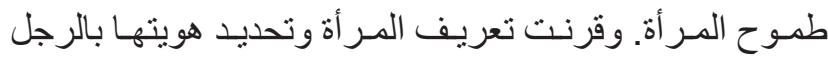

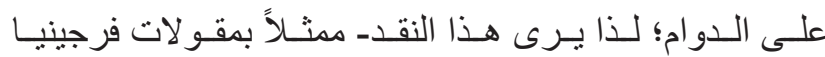

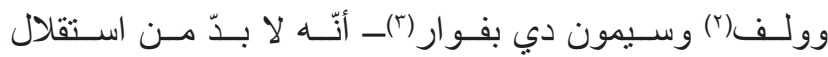

عبـر عقـود مديـدة مـن سـبطرة الخطـاب الذكـوري و أنسـاقه

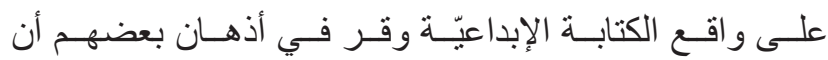

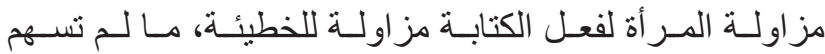

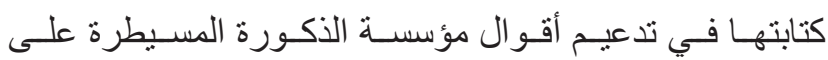

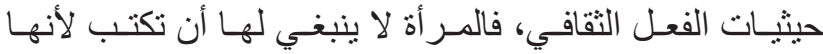

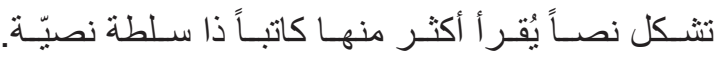

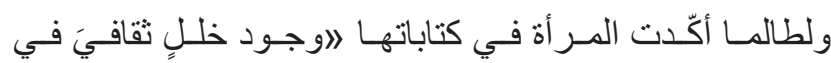

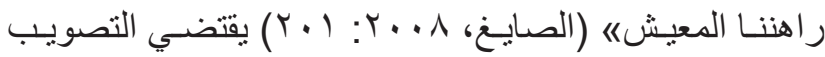
وتجـاوز مقولـة أن لا فرق بيـن كتابــة مصدر هــا الرجلـ وكتابــة

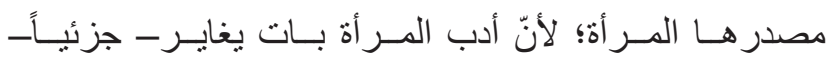

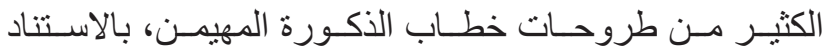

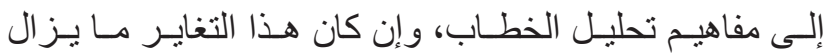

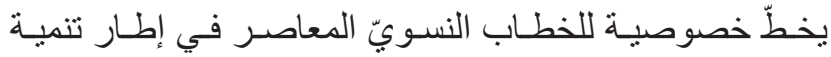

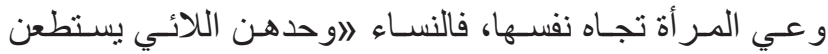

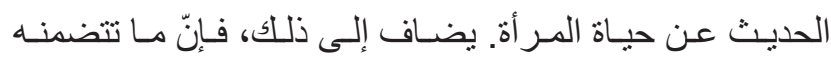

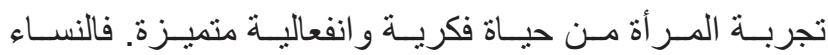

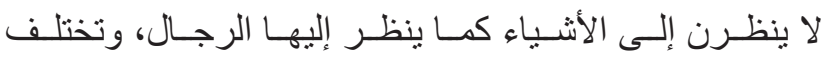

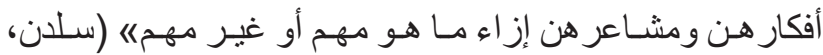

. (197: 1910

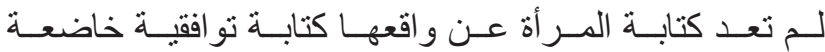

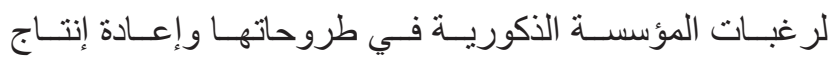

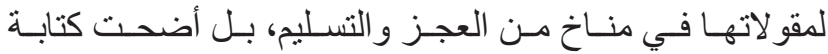

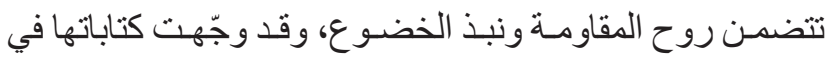

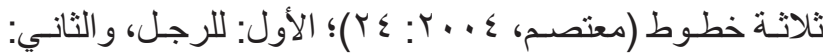

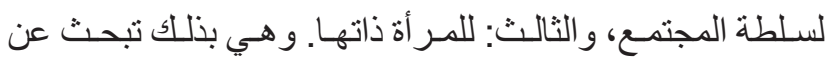

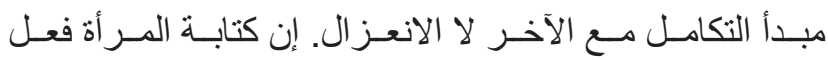

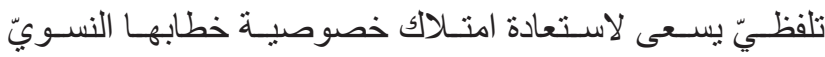

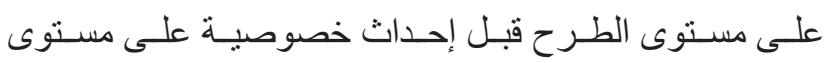

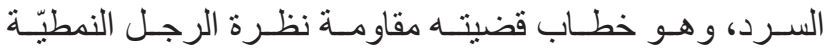

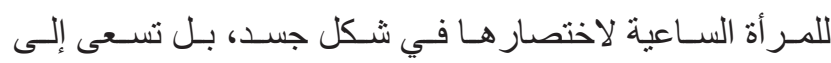
إحـال هـذه النظـرة المعدّلـة في ذهنيـة المـر أة نفسـهـا.

وقد شـر عت الدر اسـة في كثـف أبعاد هذا الخطاب المستـدث

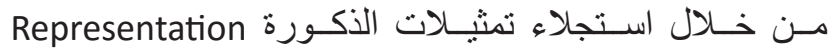

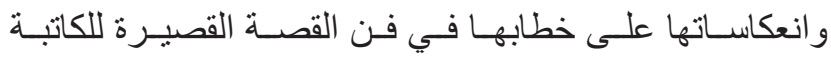

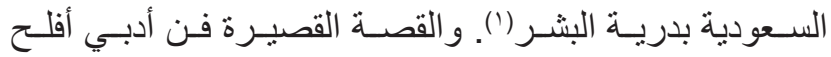

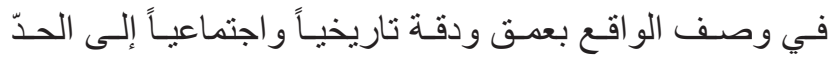

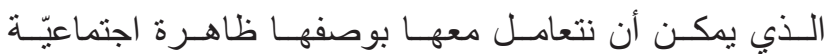

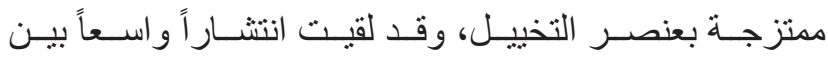

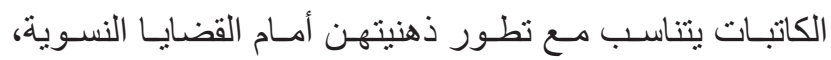


أو الأخ أو الـزوج أو الابـن.... و عملـت على لاحصـر الـذات

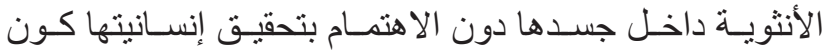

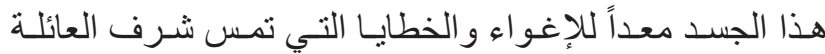

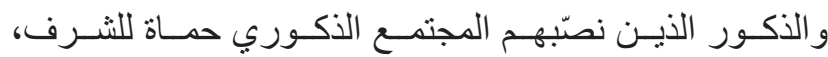

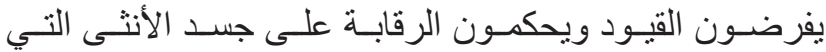

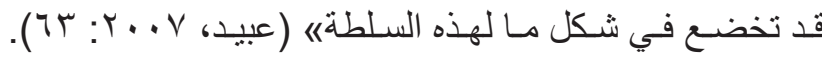
لقد قـادت هـذه الممارســة الســلطوية إلـى دعـم نسـق ثقافـي

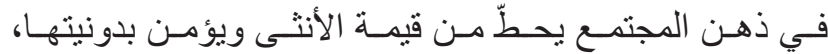

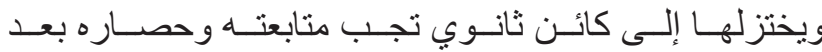

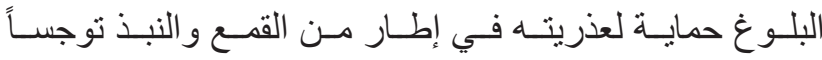

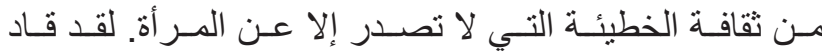

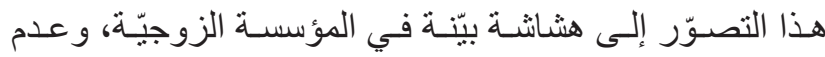
تكافؤ أعمدتهـا، مدـا دفـع الكثيـر مـن النسـاء إلـى الإيمـان بهذا

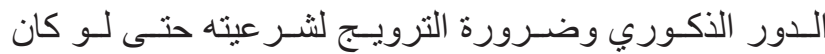
ولـي الأمسر هـو أصغـر الأبنـاء.

\section{1 ـ Y ملامح السيطرة الأبويّة:}

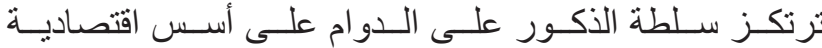

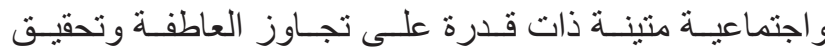
الإخضــاع و المنـع و التقبيــد و إلغــاء فكـرة الاسـتقالال و التحـرّر

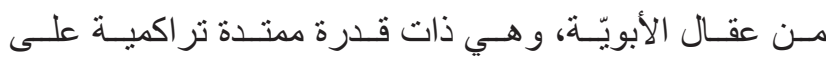

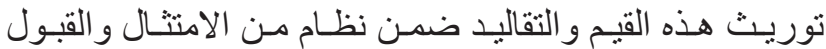

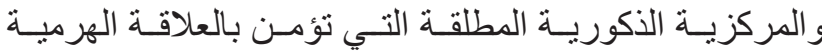

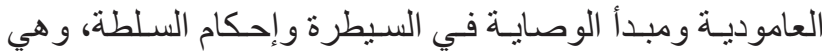

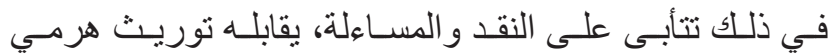

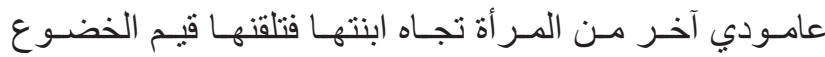

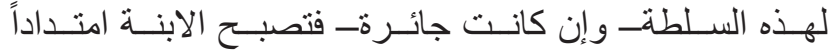

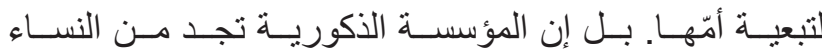
الخاضعـات عونـاً فـي تثبيــت معالـم هـذه السـلطة و الترويـج لأحقيتهــا المكتسـبة.

لقـد توزّ عـت ملامسح السـبطرة الأبويّهـة على نمـاذج سـلطوية

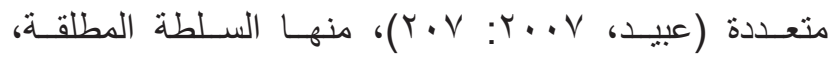

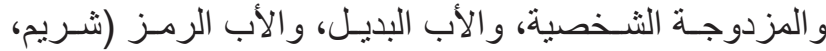

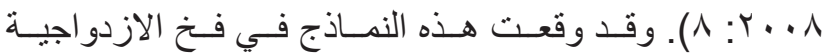

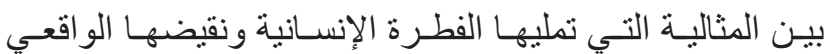

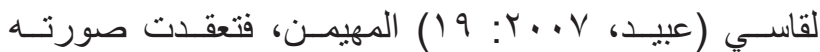
كثيـر اً، ســواء فـي بعدهــا الثـكلي (ملامحهــا الخارجيـة)، أو أو

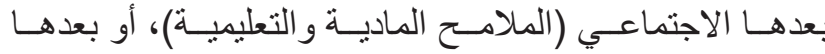

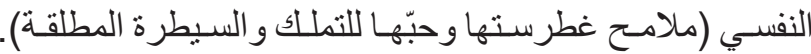

إن هـذه التمظهـر ات الذكوريـة المتناقضــة اتفقــت علـى مبـدأ
المـر أة فيمـا تتـتج مسن أعمـال أدبيـة شـكلاً ومحتوى للحـدّ مـن

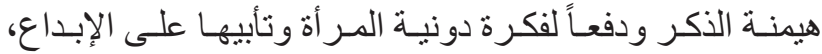

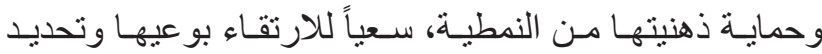

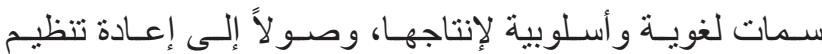

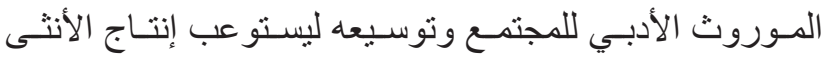

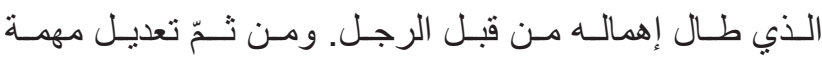
الكاتـب الأنثويـة و إناحسة تمثيـل المـر أة لذاتهـا وتصويـب دور هـا في الذهنيـة الأبويـة. ويكاد يكون النــوذج الأدبـي الذي تقدمسهـ

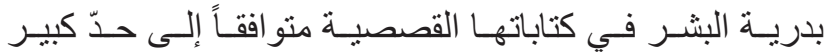

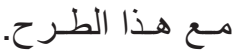

\section{1- تمثيلات الأكورة:}

ا - إ تمهيد:

ونعنـي بالتمثيـلات Represents مجمـل أشـكال حضـور الآخر

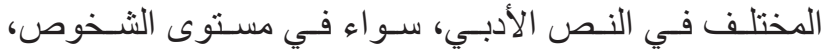

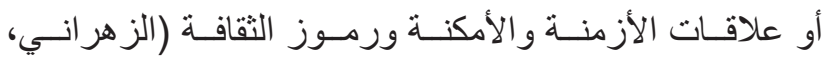

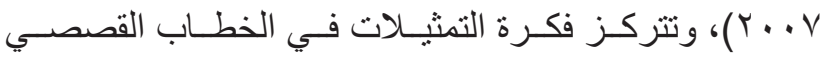
لبدريـة البشـر علـى الآخـر الذكـوري المنطلـت مسن مـوروث

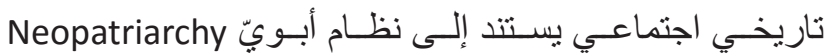
مطلـق السـلطة. تتطلق بدريـة البشـر في تمثيلاتهـا الذكوريـة مـن رؤى و أحكام

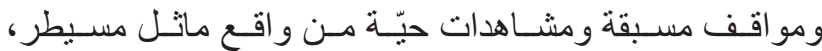

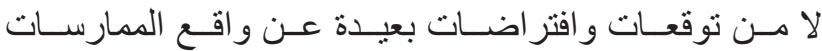

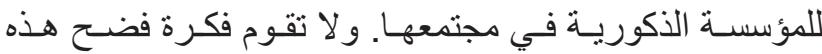

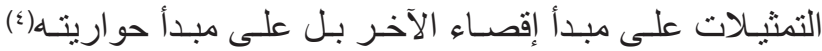
و مشــار كته هـذه السـلطة.

إن قـر اءة هـذه التمثيـلات تنتمـي إلـى سـياق در اسـات صـورة

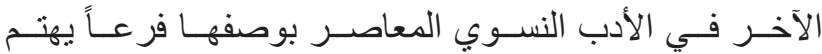
بإبـر از ملامــح القسـم الغامـض مـن الكتابـة الإنسـانية يقـاوم

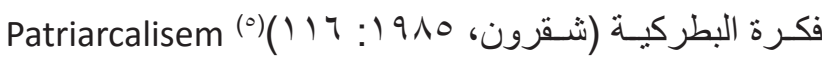
في المجتمـع العربـي المحافظ، وهذه الفكرة المر ادفـة لمفهوم

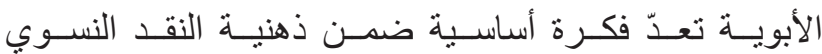
لممارسـات الرجـلـ وسـطوة الواقـع الاجتماعـي الداعـم لــه،

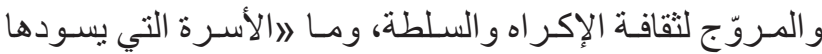

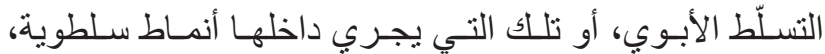
ليسـت هـيـ في نهايـة الأمـر - إلا نموذجـاً مصغـر آ لمـا يجري

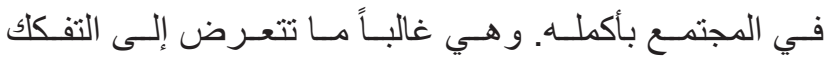

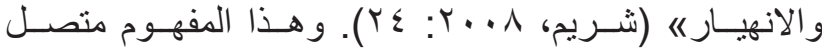

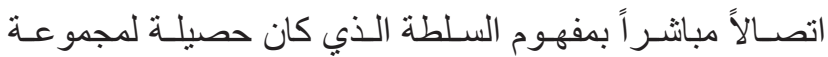

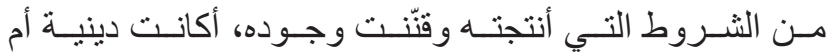

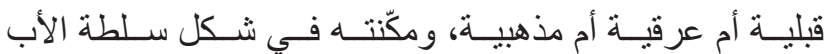




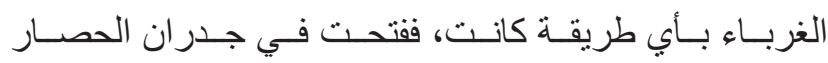

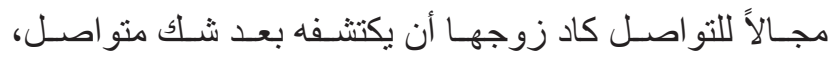

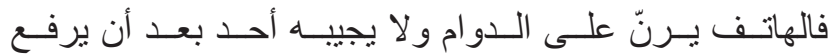

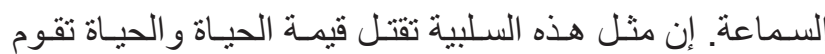

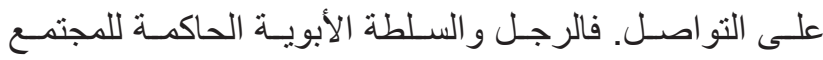

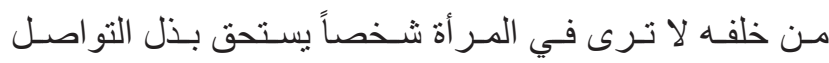

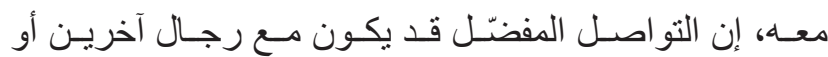

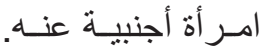

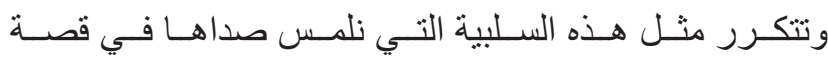

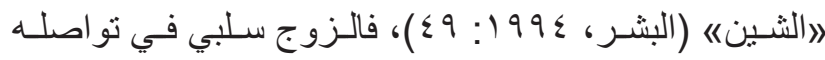

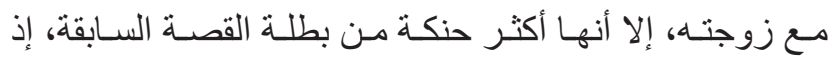

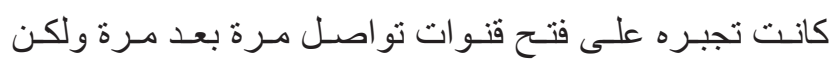

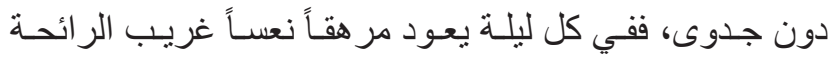

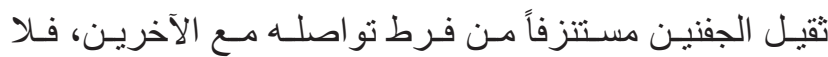

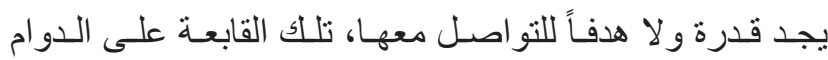

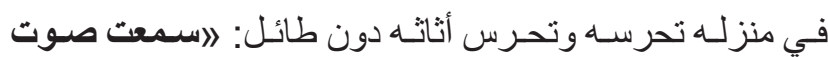

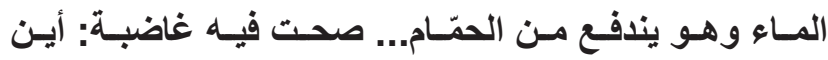

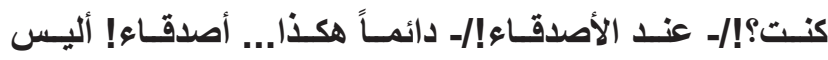

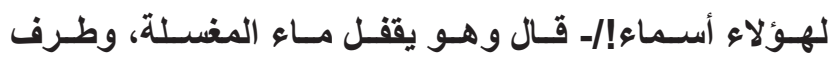

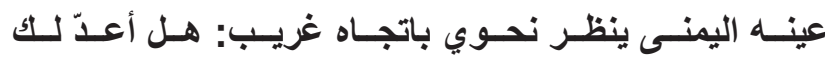

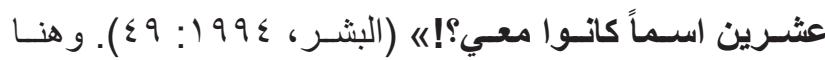

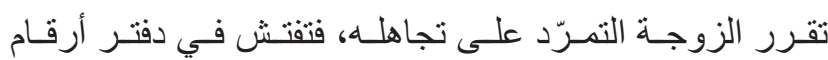

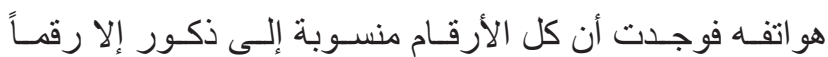

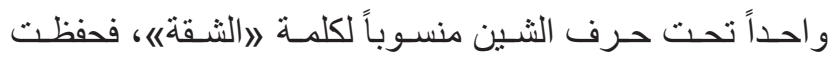

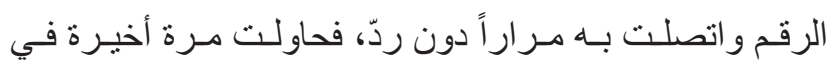

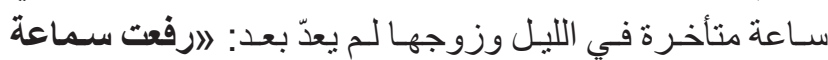

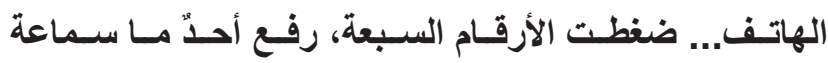

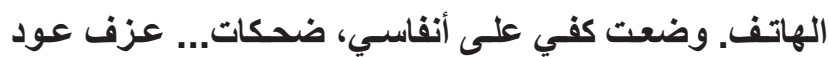

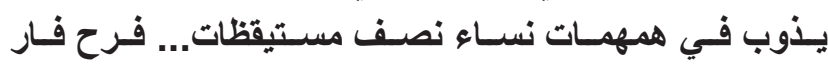

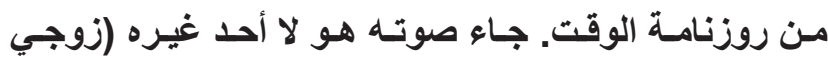

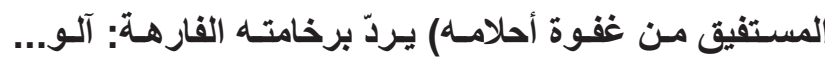

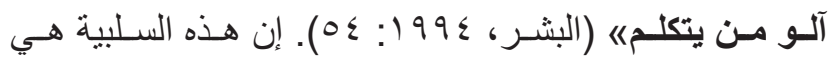

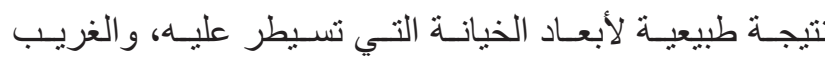

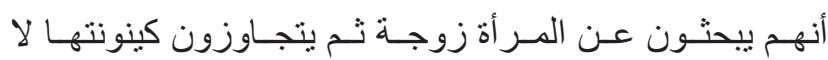

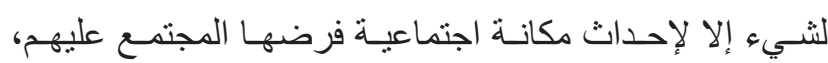

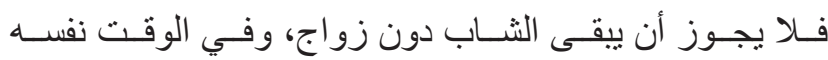

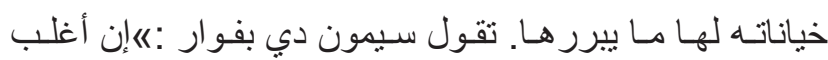

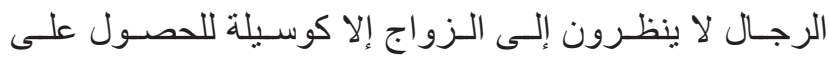

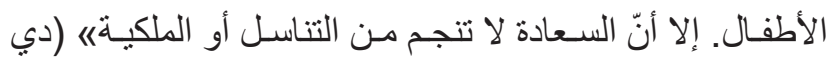

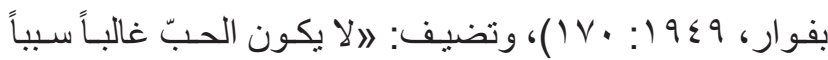

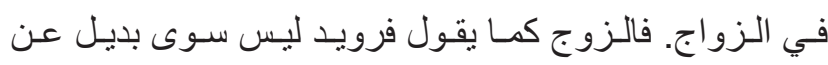

فرض الهيمنـة واتخـاذ الأنتى لاخصمـاً يجب إخضاعـا إمعانـاً

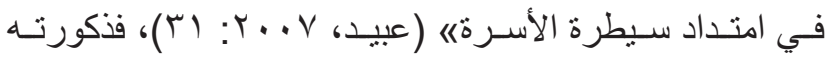

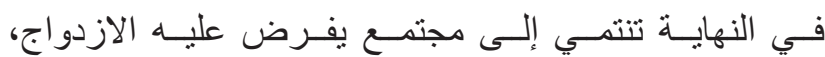

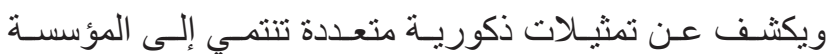

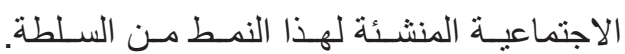
1-r أنماط تمثيلات الذكورة: وتتوزع على ما يأتي:

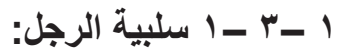

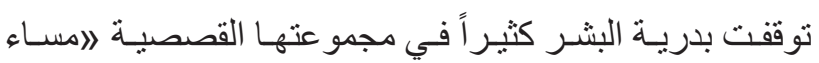

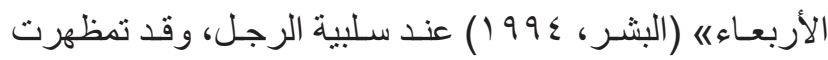

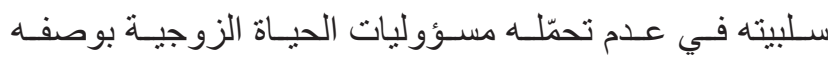

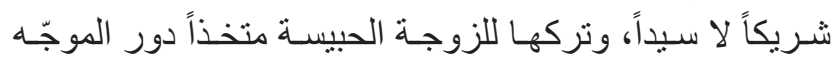

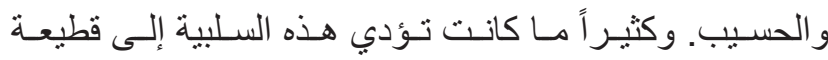

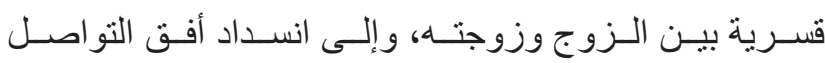

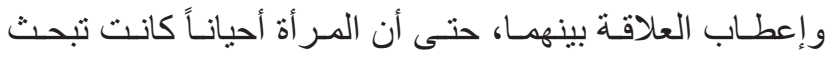

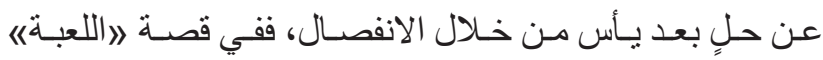

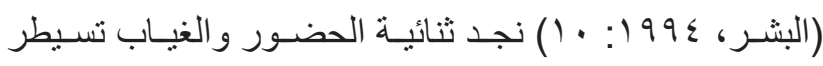

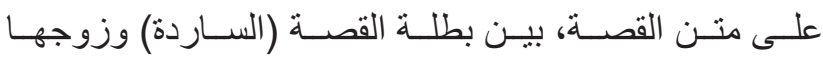

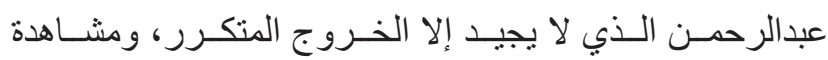

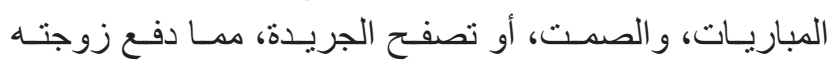

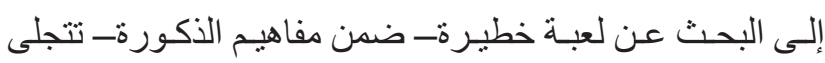

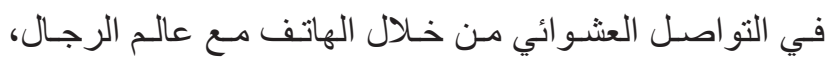

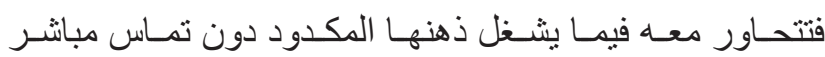

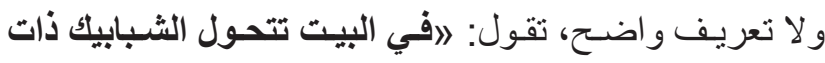

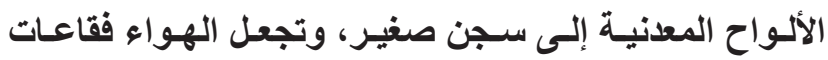

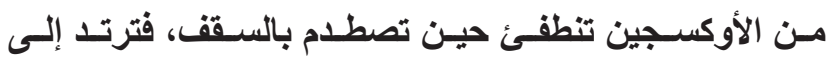

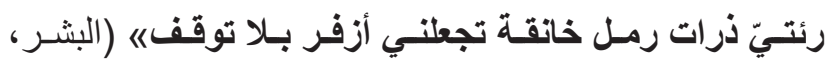

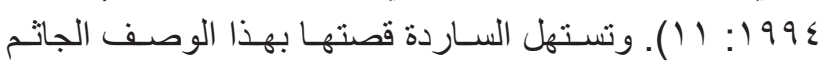

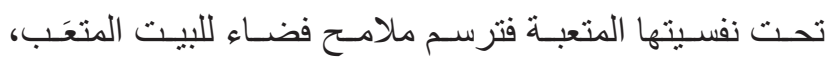

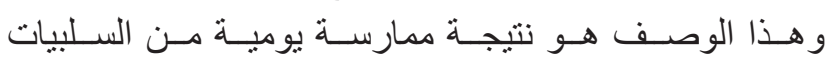

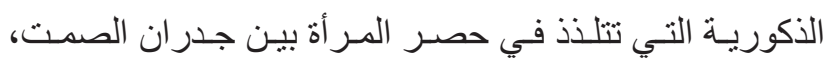

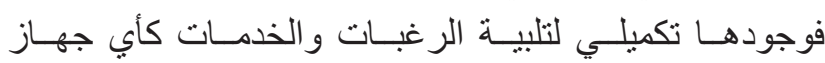

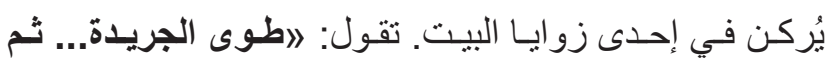

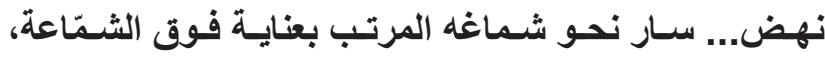

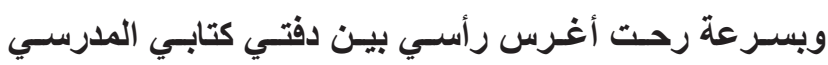

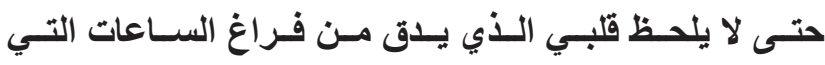

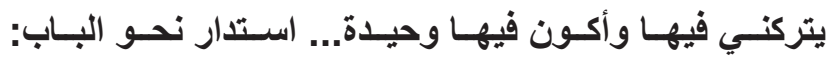

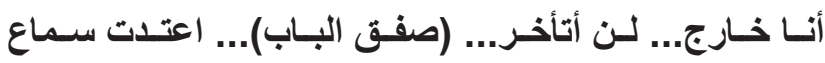

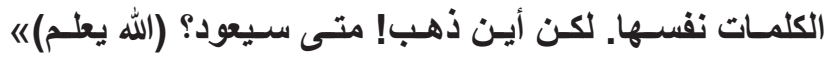

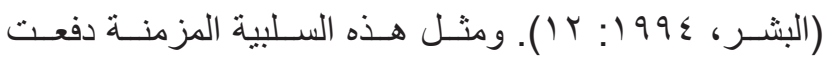

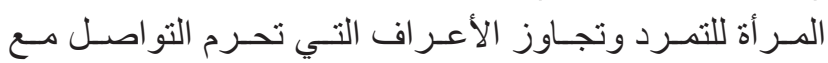




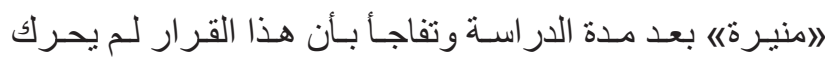

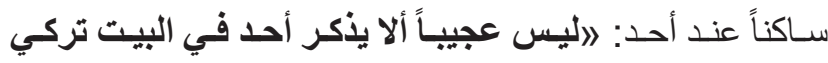

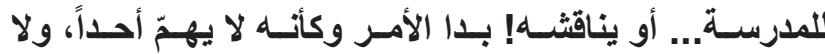

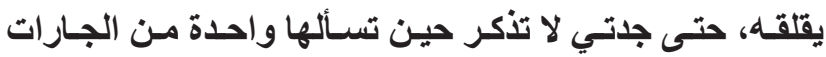

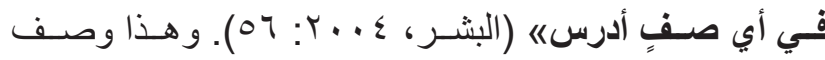

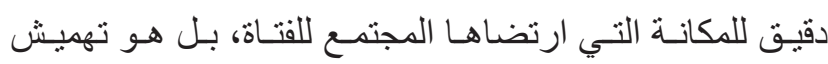
ترعـاه النسـاء أنفسـهن كالجدة و الأم، كل ذلك مـن أجلـ انتظـار

$$
\text { قطـار الـزواج الـذي تأخـر. }
$$

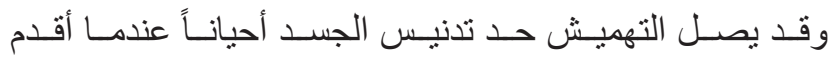

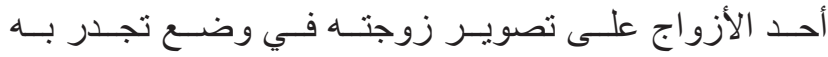

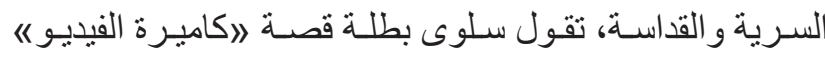

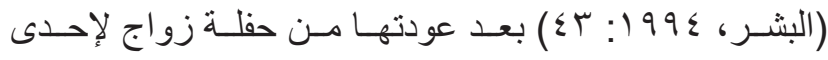

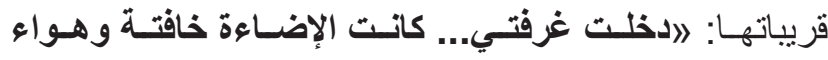

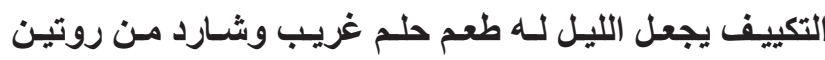

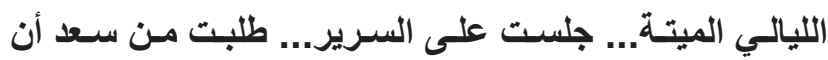

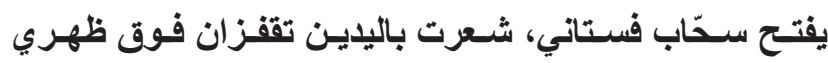

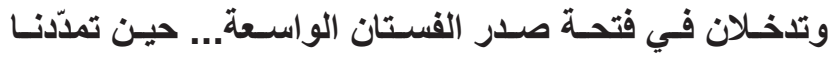

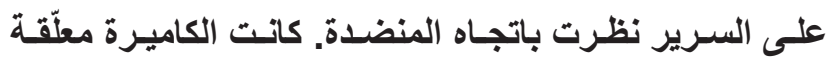

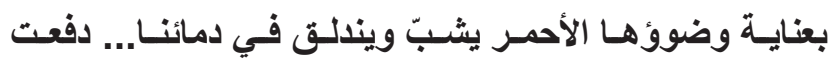

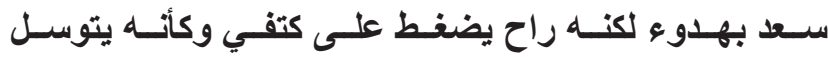

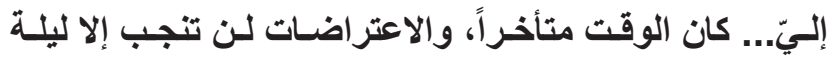

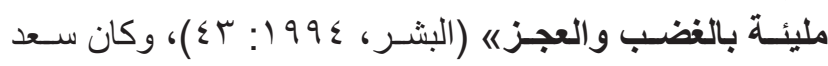

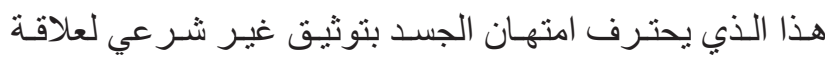

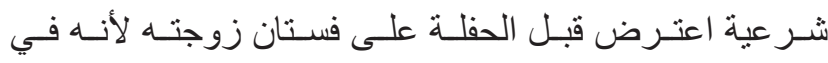

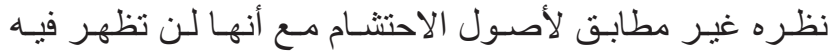

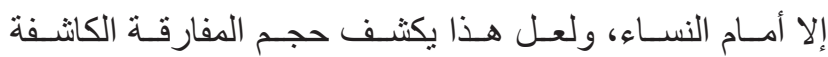

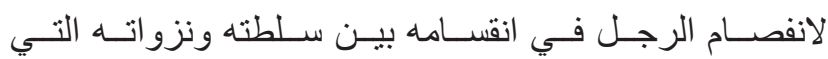

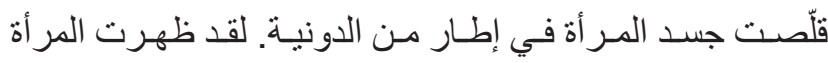

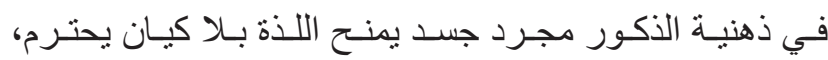
فالرجل هنـا الايجد العملية الجنسية تأكيداً لثـخصيته وامتداداً

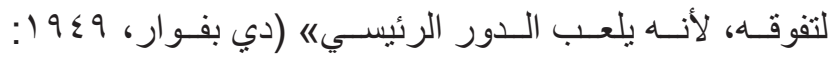

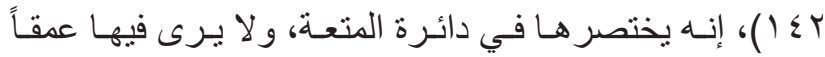

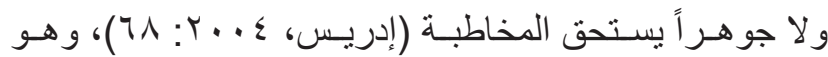
تأكيد لدونيتهـا و إباحسة استخغلالها وممارسـة الاسـتهلاك عليهـا.

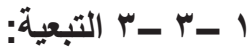

يسـعد الرجـل كثيــراً وترتفع طمأنينتهـه عندمـا تكـون المـر أة تبعـاً

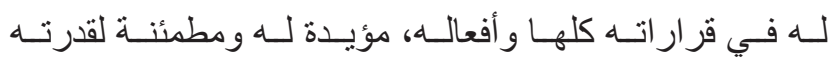

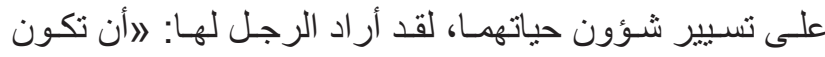

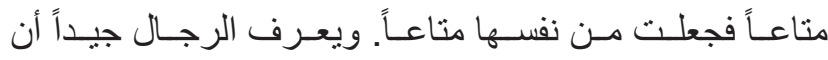

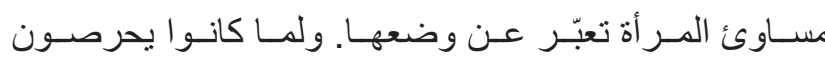

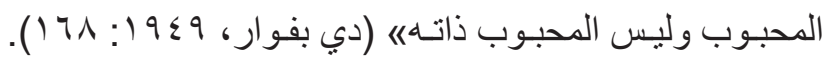
وهـذا نمـط مـن التمثيـلات الذكوريـة يحقق شكلاً مـن أنشكال

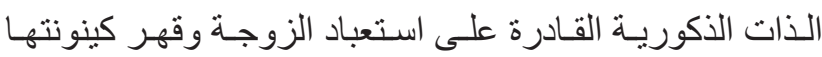

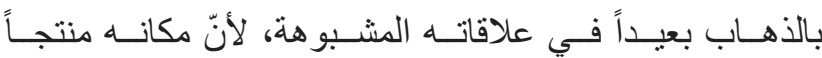

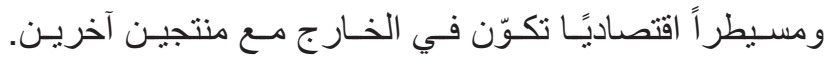

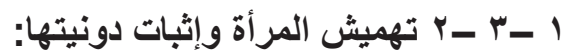

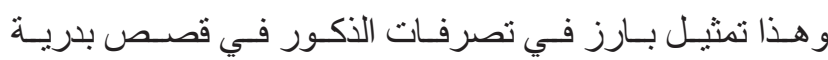

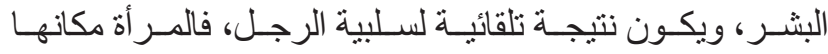

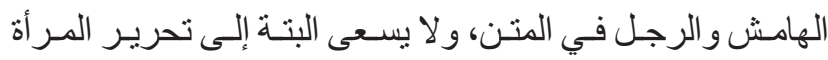

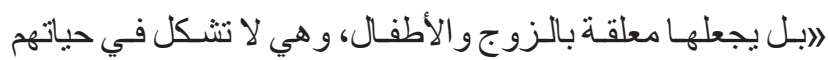

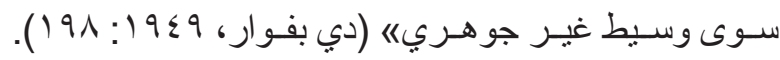

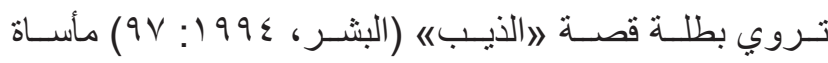

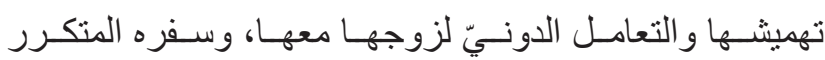

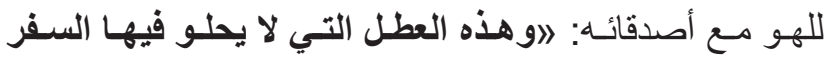

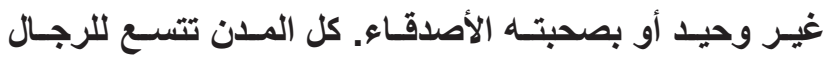

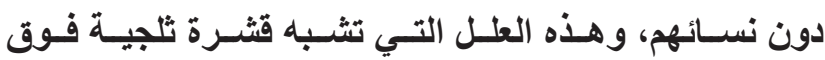

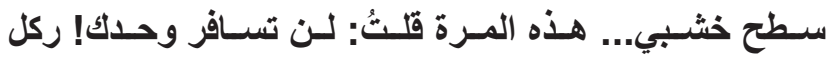

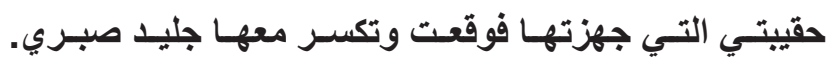

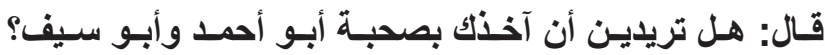

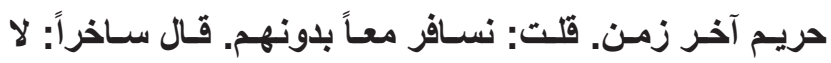

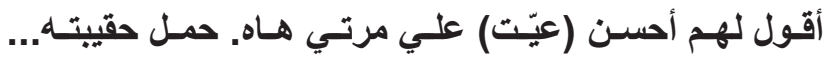

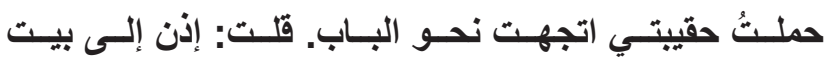

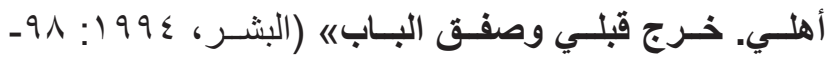

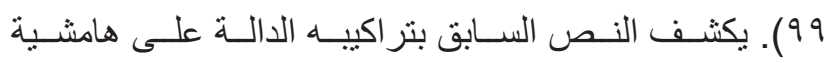

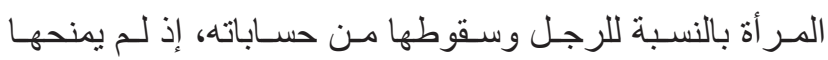

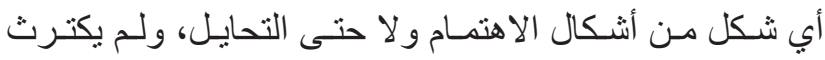

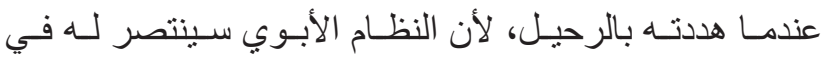

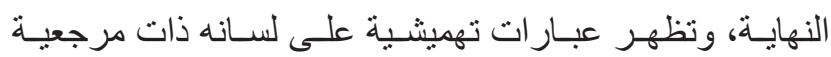

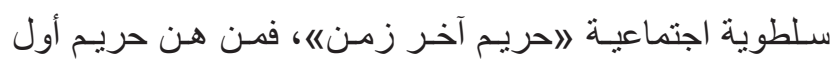

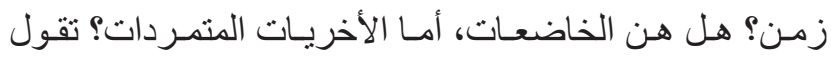

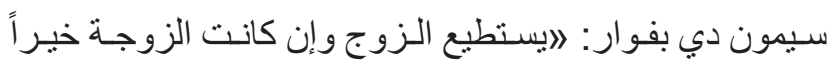

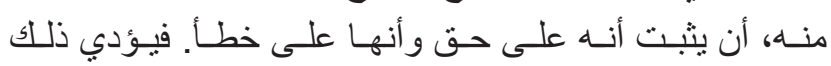

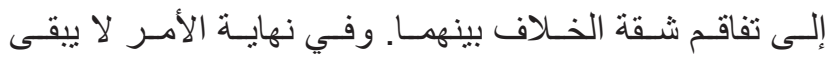

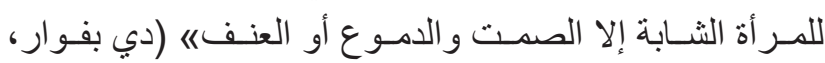

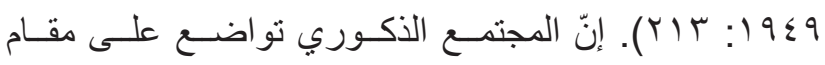

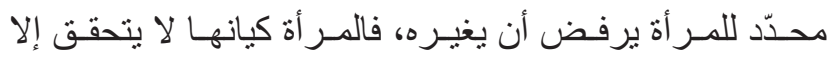

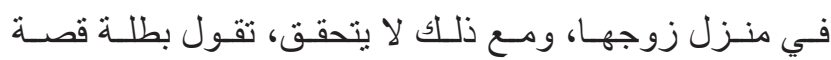

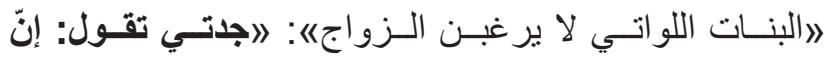

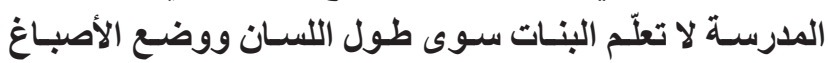

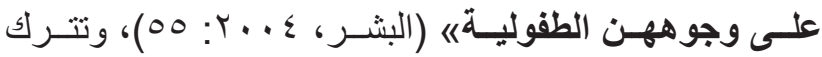


لـم تكمـل... ركل كلماتهـا بســاعد يـده اليمنسى وقـال: قولـي لـهـ

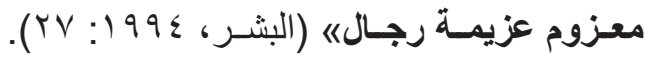

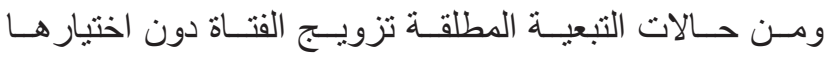

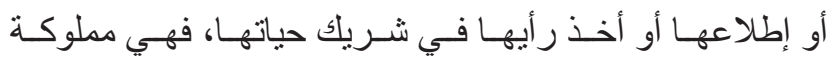

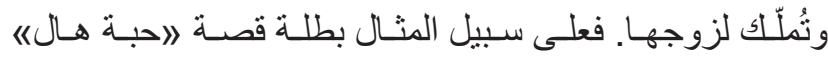

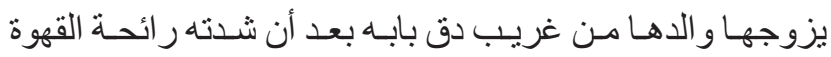

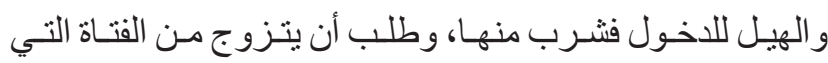

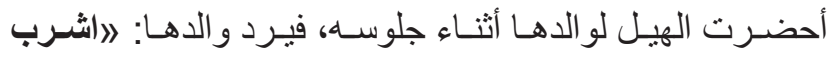

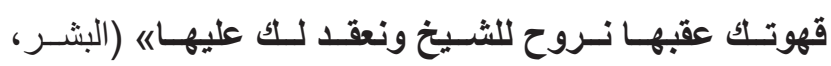

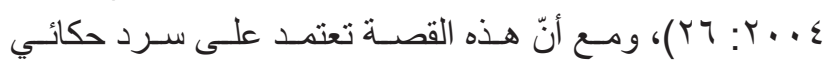

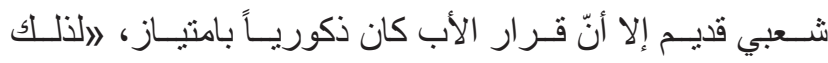

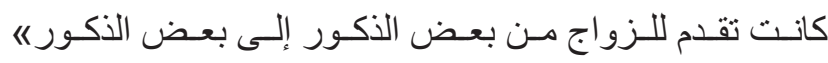

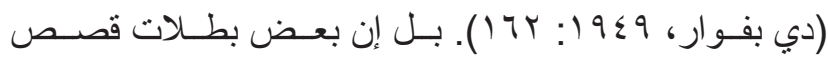

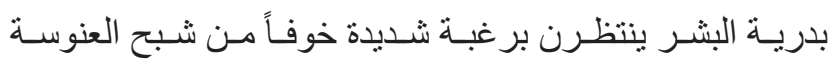

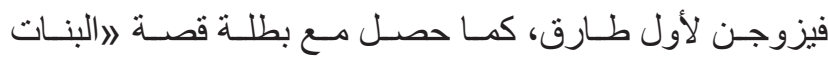

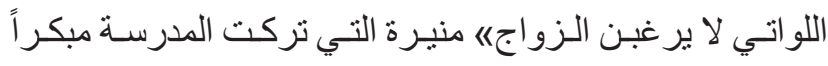

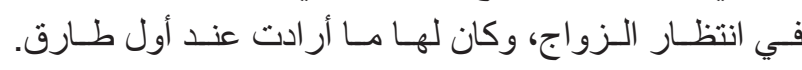

لكـن الإشـكالية الكبـرى أن القتــاة تُمنـع مـن رؤيــة هــا القـادم

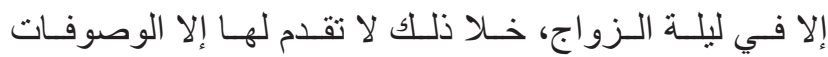

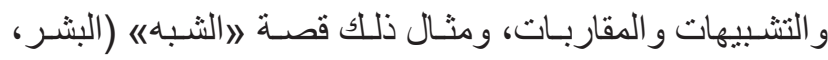

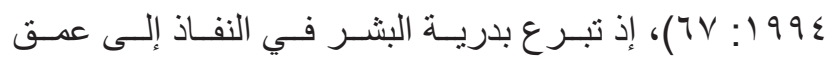

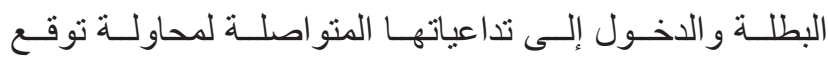

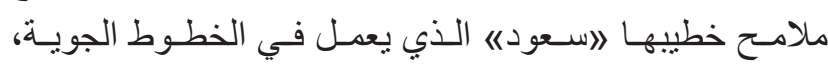

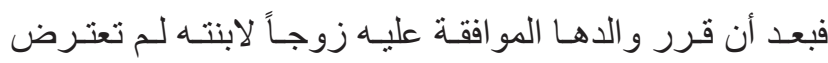

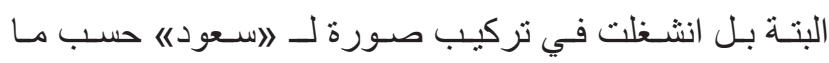

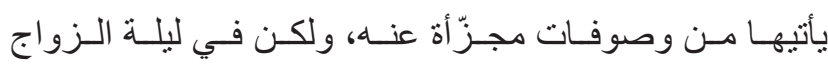
رأتسه: لاصعـــ العريسس بخطوتيـن عتبـات المنصــة وهـي

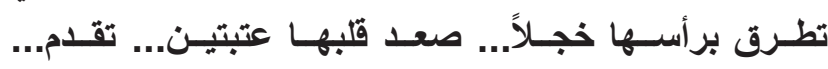

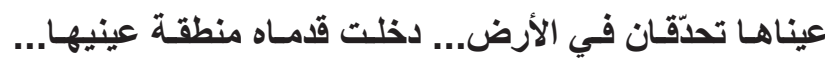

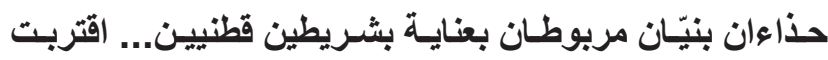

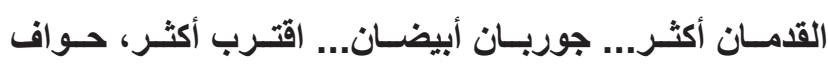

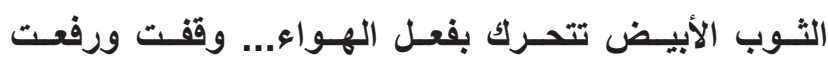

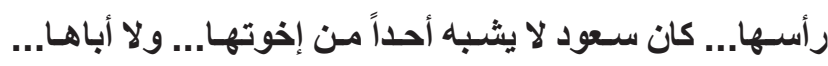

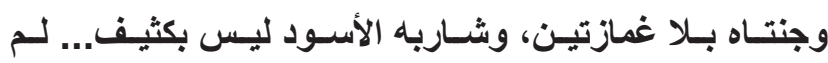

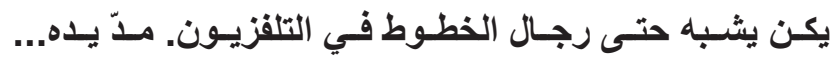

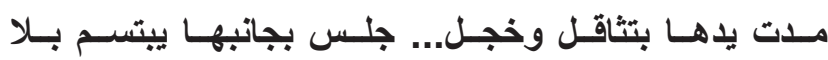

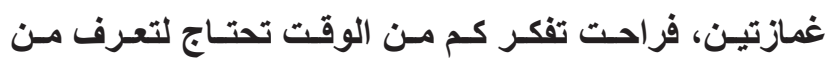

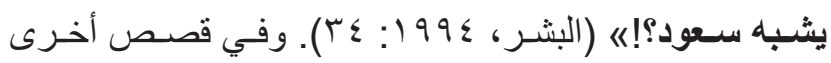

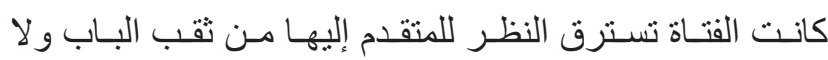

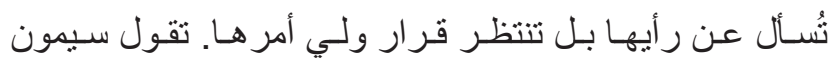

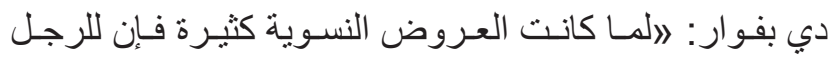

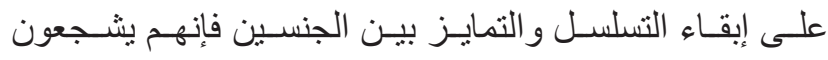

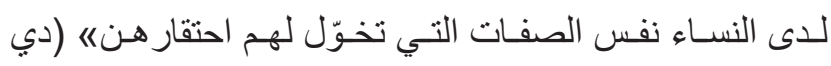

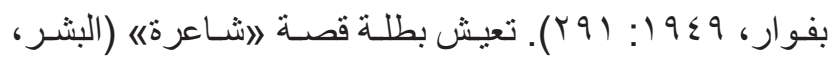

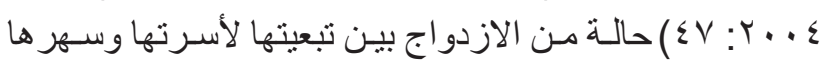

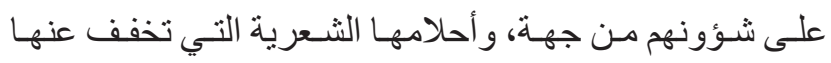

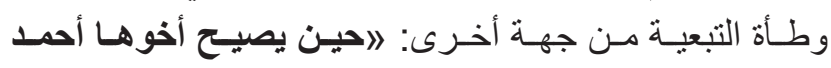

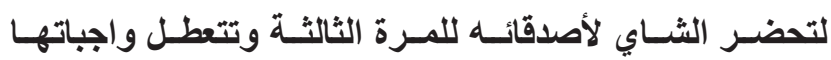

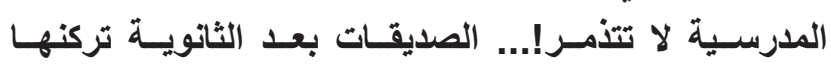

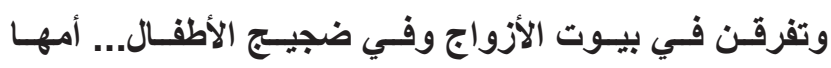

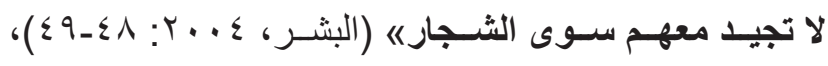

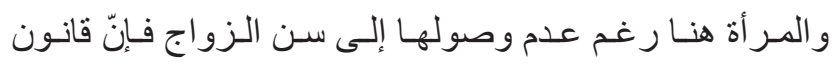

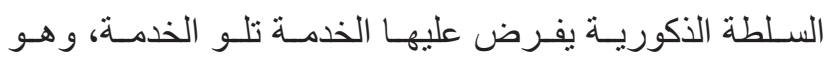

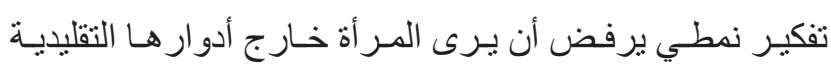

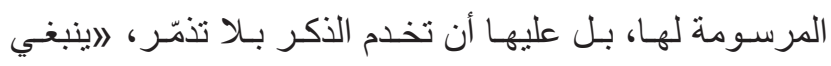

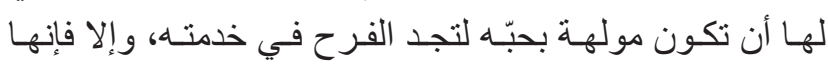

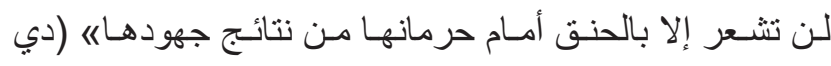

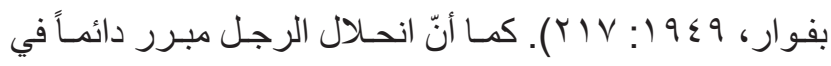

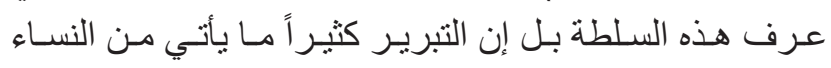

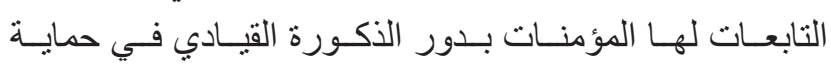

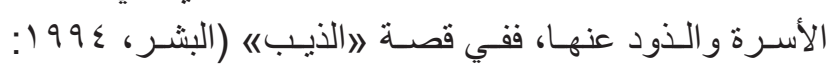

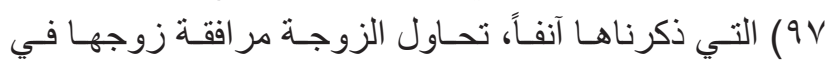

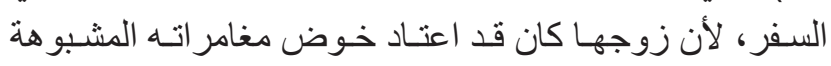

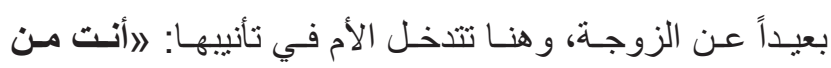

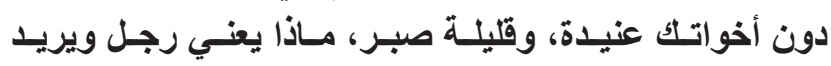

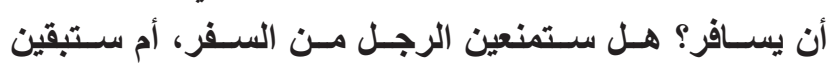

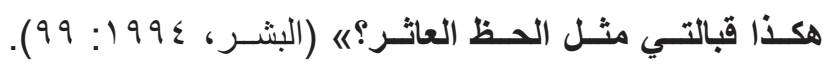

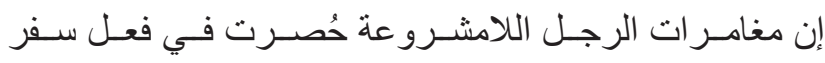

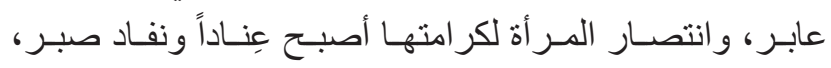

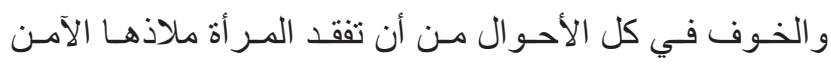

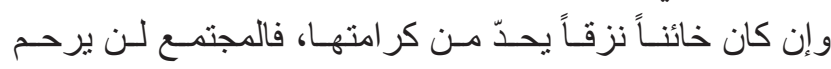

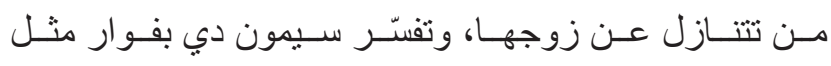

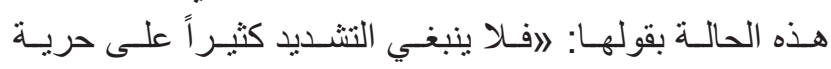

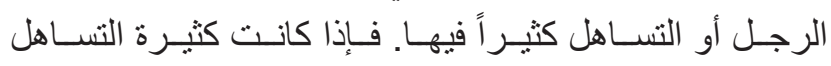

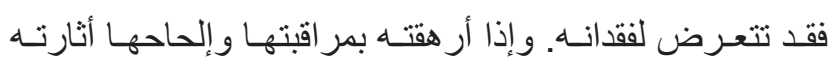

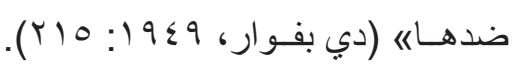

و على المـر أة كذللك التصدي لتنظيم الحيـاة الخارجيـة للأسـرة

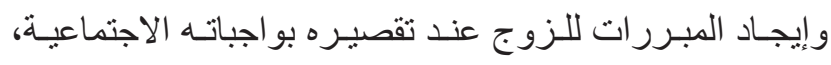

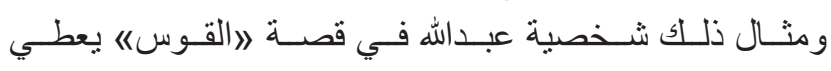

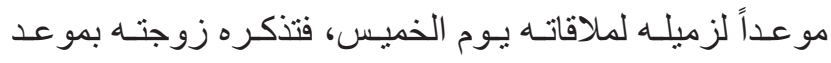

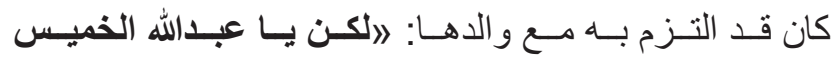

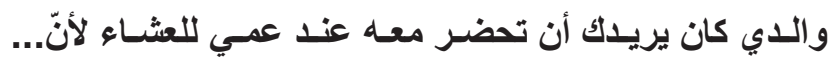




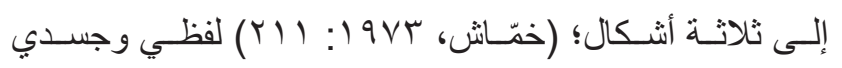
ونفسـي:

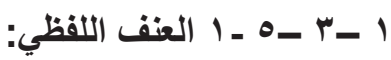

ويقصــد منـه إهانـة الآخـر وتقزيمسه، وقـد نـالــ نسـاء بدريـة

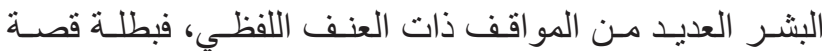
》امسـاء الأربعـاء|《، وبعـد انتظـار طوبـل لعودة زوجهـا، ويـوم

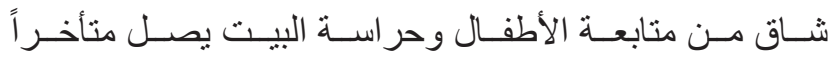
وهي في انتظـار ه، فيبادر هـا قائـلاً: المهـاذا تقفيـن هكذا مثل

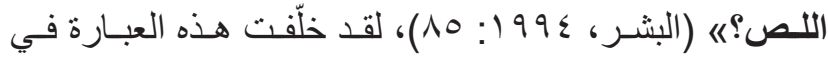
نفسـية المـر أة انكسـار اً كبيـر آ، فبعـد وفائهـا اليومسي المتكـرر

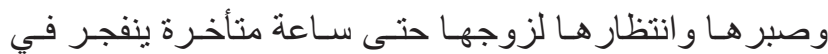

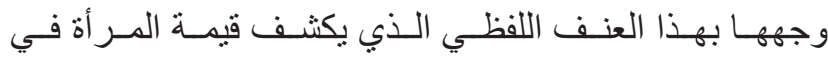
ذهنيـة الرجـل المسـتبد.

ويمكن أيضــا أن تجابـه المـر أة بتحـرش لفظـي مـن قبـل أفر اد

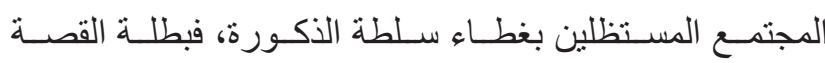

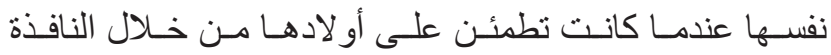

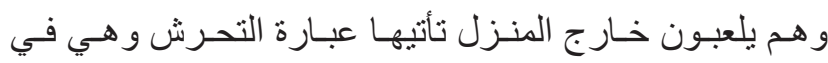

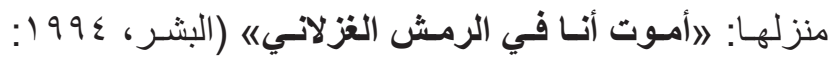

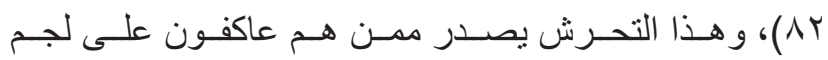

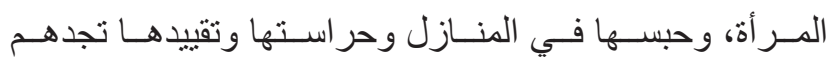

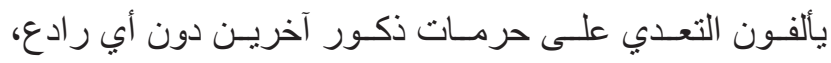

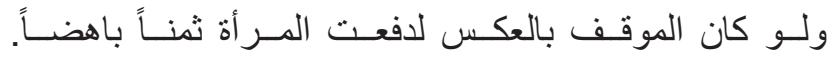

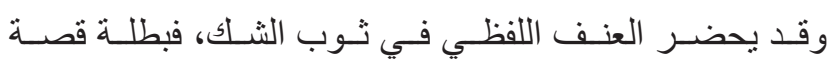
القوس《 الـي احترف زوجهـا تصديـر رقم هاتفـه إلىى كل

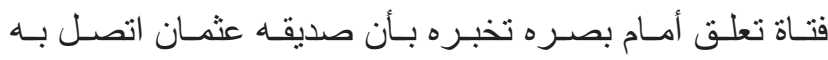

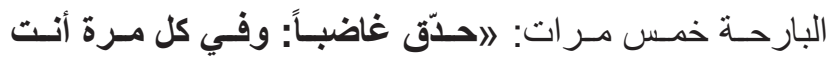

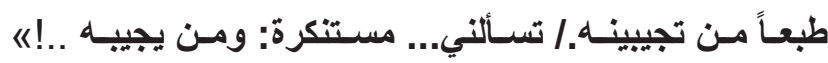

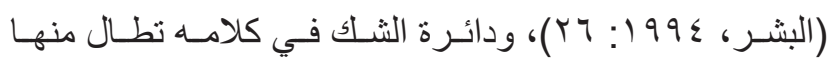

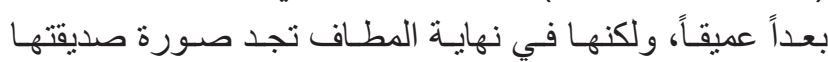

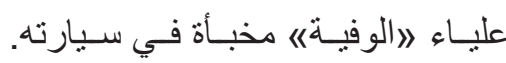

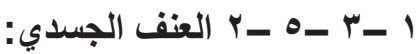

ويحضـر هـذا النـوع مـن العنـف بكثـرة فـي الأدب النسـوي لسـهولة الإقدام عليـه في ظل الفـروق البيولوجيـة بيـن الاثثين

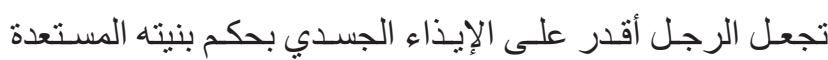
دومـاً للتعـدي على الجميـع فـي ظـل غيـاب محـددات المبـدأ

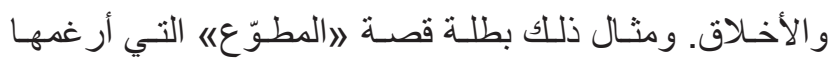

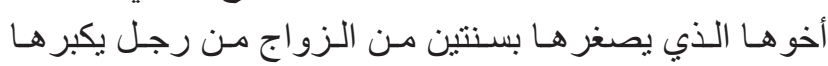

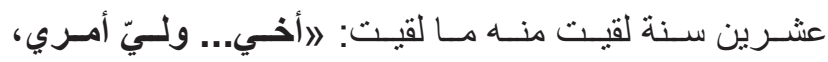

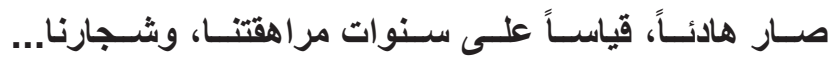

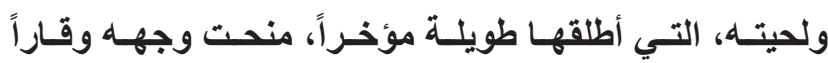

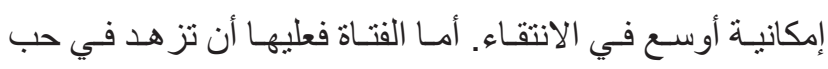

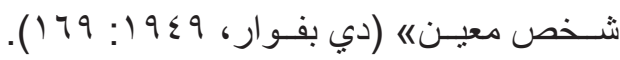

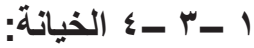

اعتنــت بدريــة البشــر فـي قصصهــا فـي تصويـر ملامــح

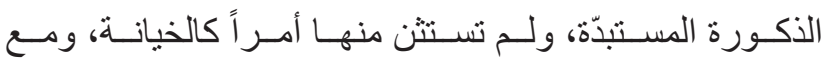

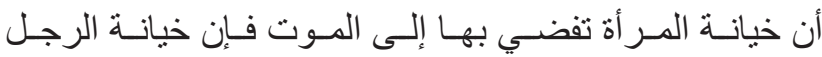

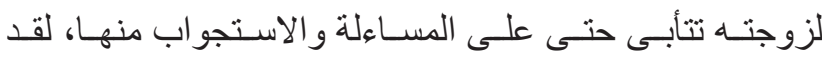

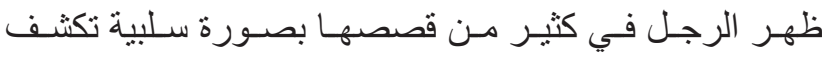
غطرسـته و اسـتمداد عزمسهـ مـن المؤسسـة الأبويـة التي تسـيّر

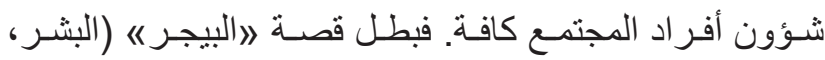

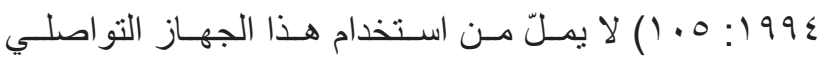

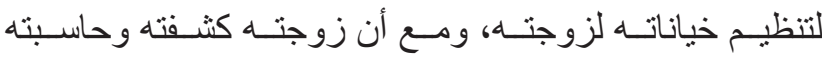

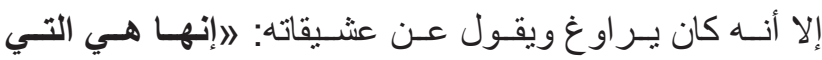

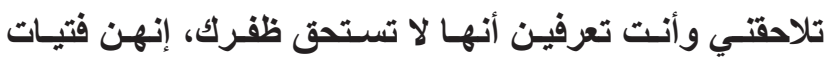
رخيصـات هـؤلاء، عابرات، يحتقرهن الرجل كلمـاتماديـن في

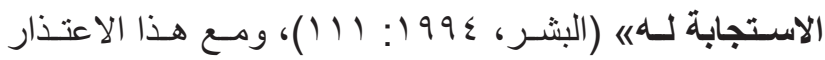
الثـكلي يعـود إلى ضلالهـ، وتصـف السـاردة اشـــز از ها منـه:

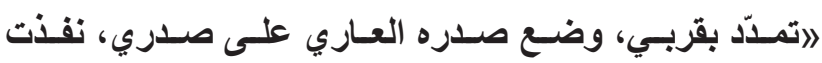

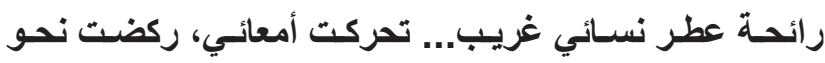

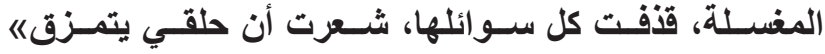

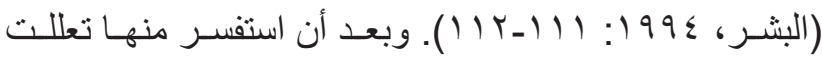
بـ 》الوحم/《؟ دون أن تقوى على مسـاءلته مـرة أخـرى لأنهـا

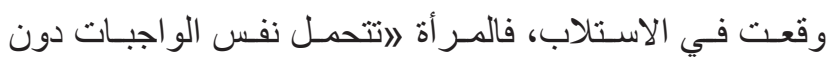
أن يكون لهـا نفس الحقوق. كمـا لا تز ال تقوم بنفس الأعبـاء

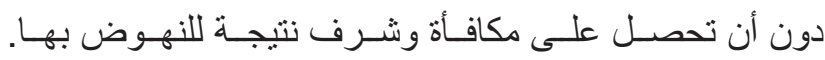

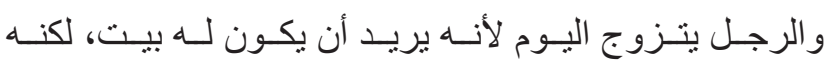

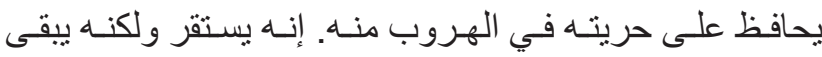

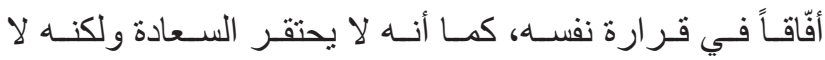

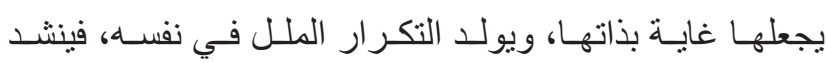
التجديـد و المخاطـر ويبحـث عـن الصداقـات التـي تنتشـله مـن

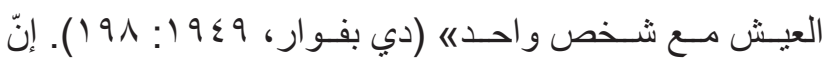

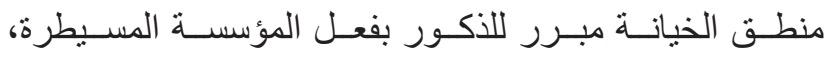
ويفسر تحــ أعـذار الغيرة و الطيش و الترفيـه، و على المـر أة

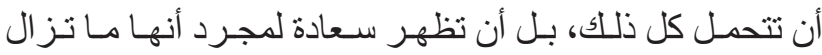

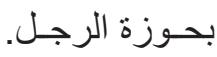

- I

أو اضطهـاد المـراة تمثيـل ذكــوري أساســي فـي تمثيـلات

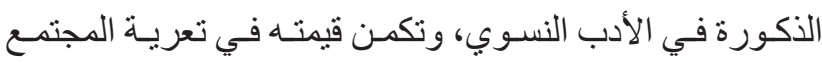

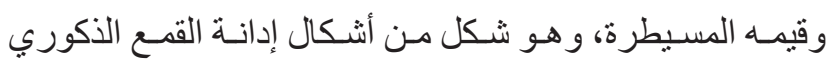

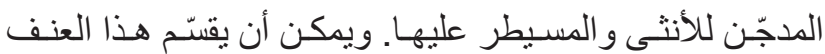




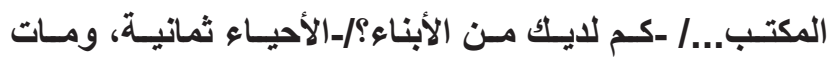

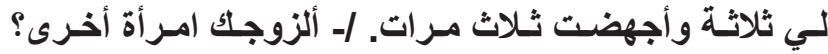

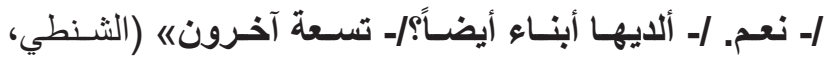

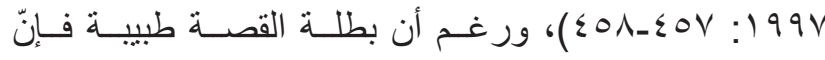

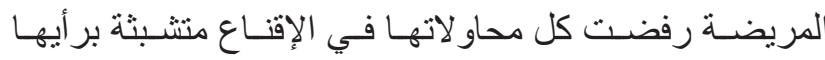
رغـم كل مـا يتهددهـا.

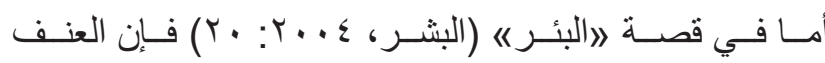

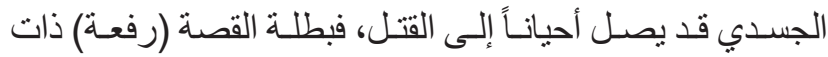
شـخصية مرحسة بيضـاء، وتحظى بزو اج سـريع دون استشــارتها

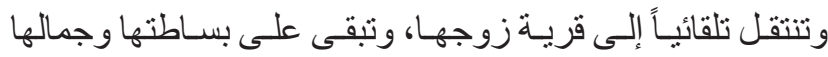

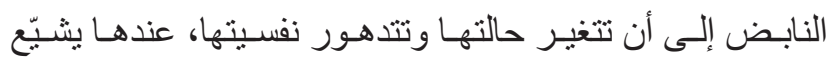

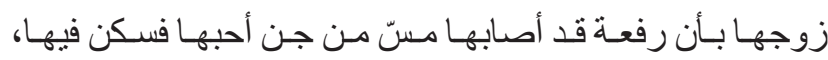

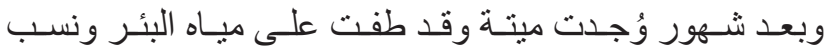

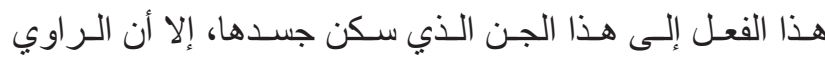

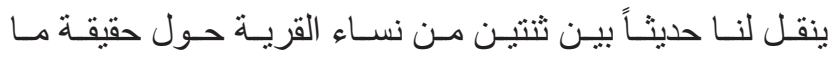

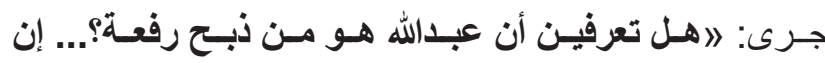

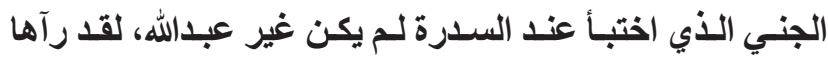

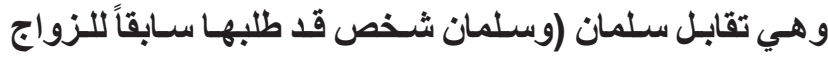

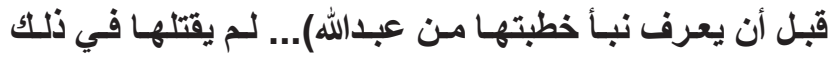

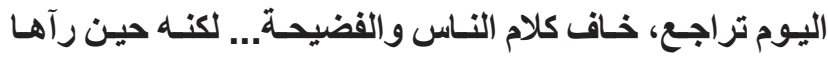

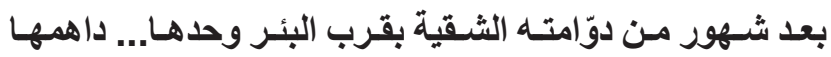

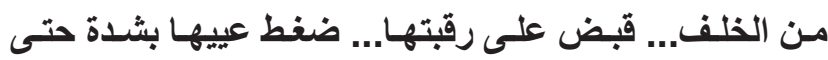

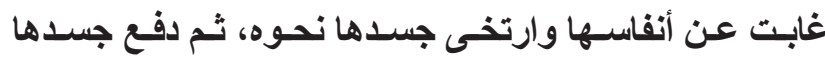

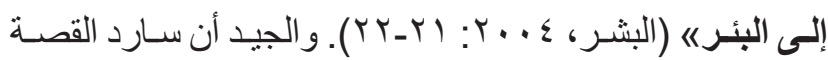

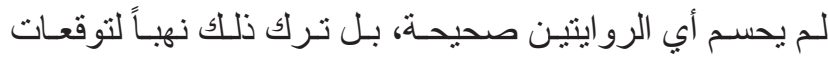

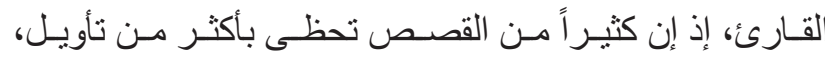

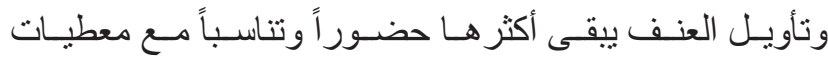

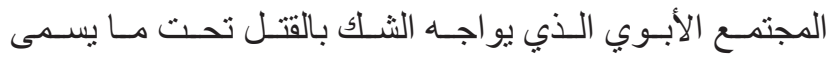

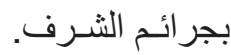

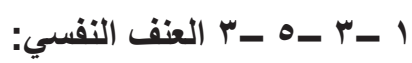

وقد تجلّى في قصص بدريـة البشـر في قصديـة الرجل إهانـة

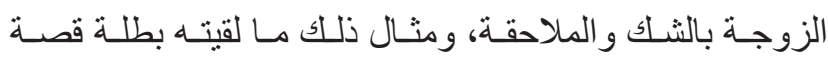

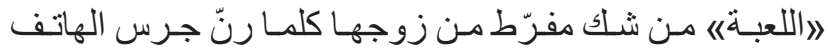

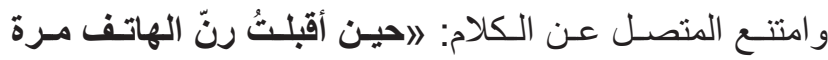

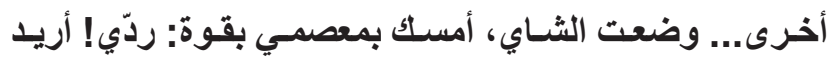

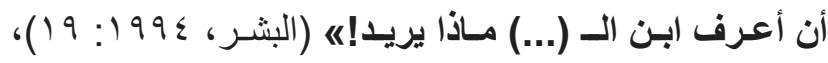

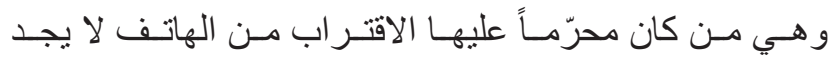

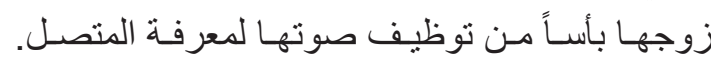

كمـا قد يظهر بجـلاء عندمـا يقـارن الرجل علنـاً زوجتـهـ بنسـاء

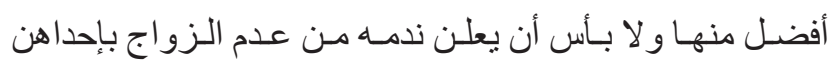

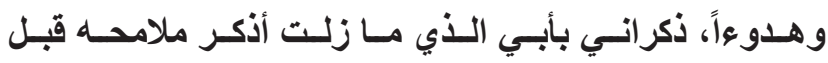

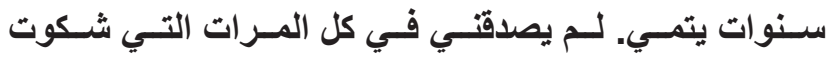

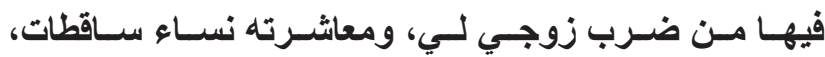

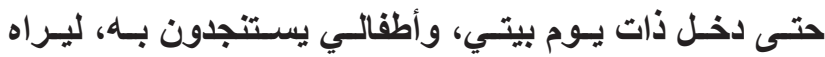

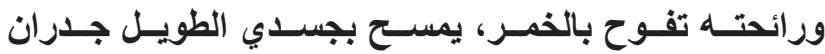

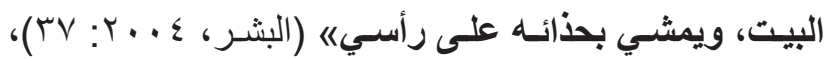

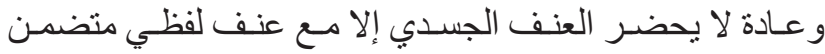

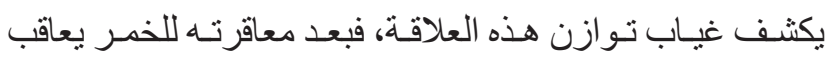

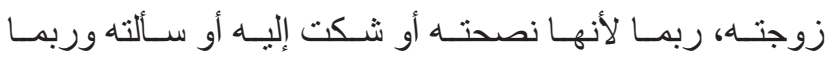

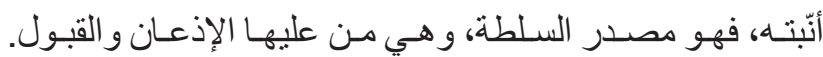

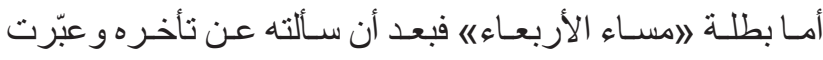

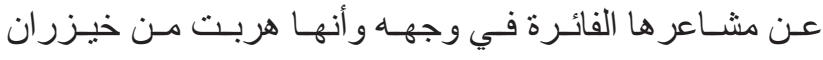

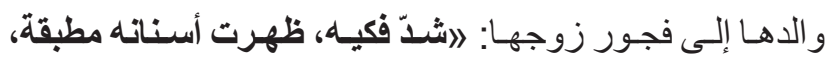

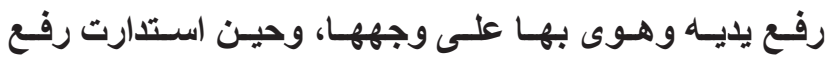

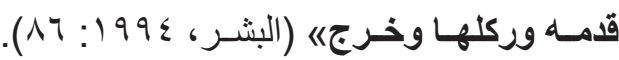
و الملاحـظ أن جميـع نسـاء بدريـة البشـر اللواتـي ينلـن عقابـاً

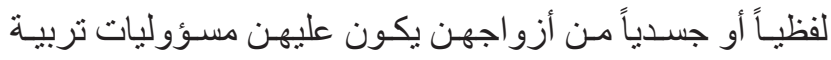

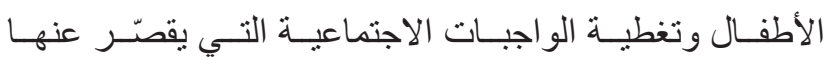

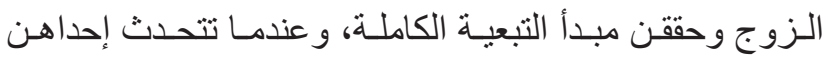

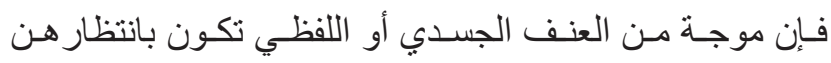

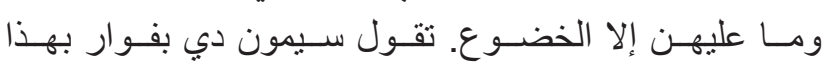

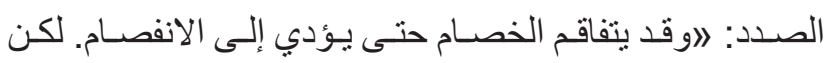

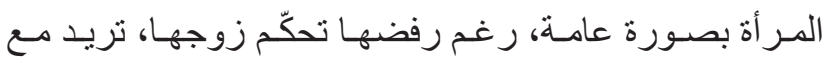

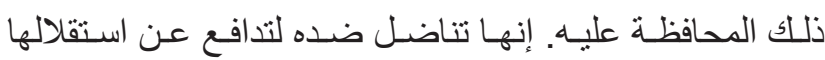

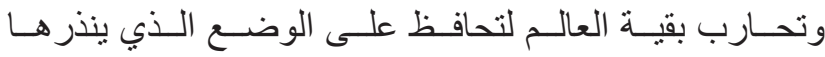

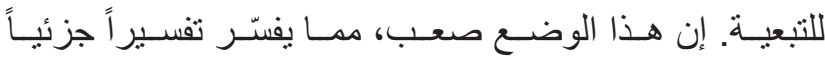

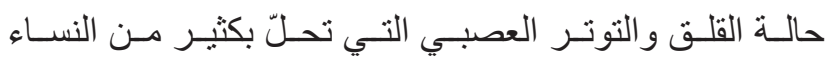

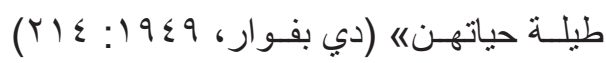

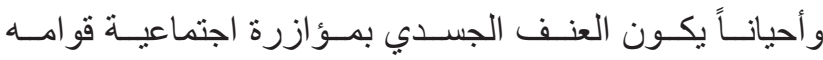

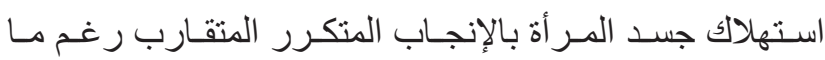

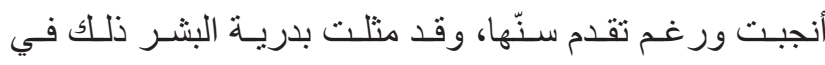

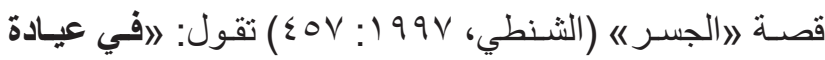

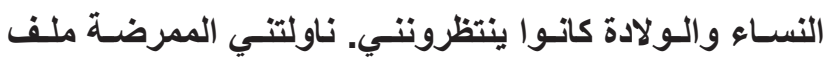

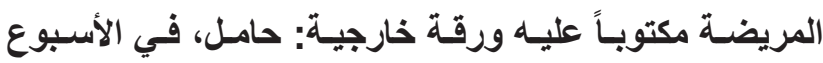

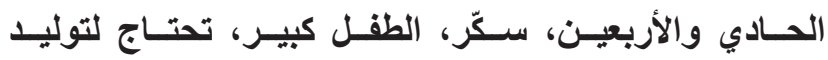

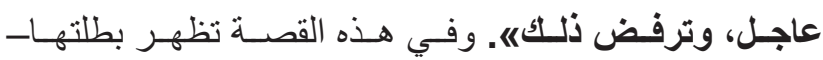

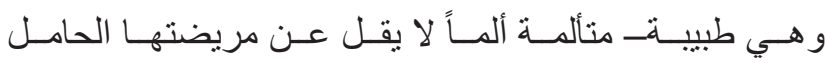

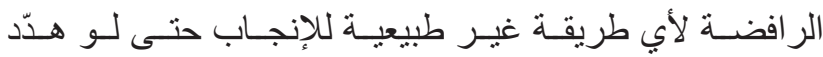
ذللك حياتها أو حيـاة طفلها: لاكاتست تجلس على على كرسي أمسام

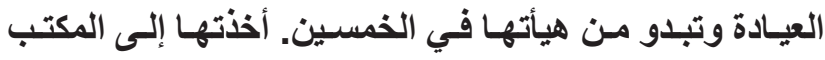

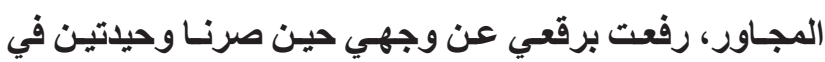


99). لا شـك أنها سـلطة الإنتـاج التـي أغرت الو الـد بإبقائهن

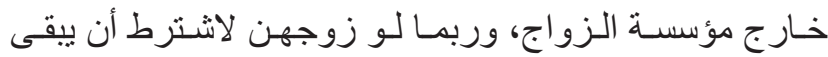

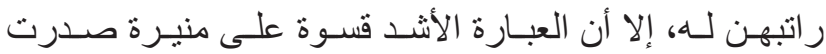

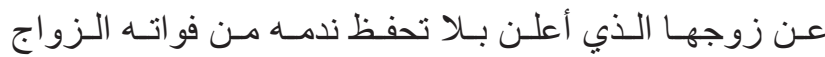
مـن إحداهـن أمسام زوجتـهـ.

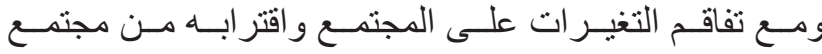

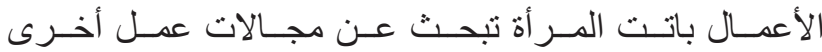

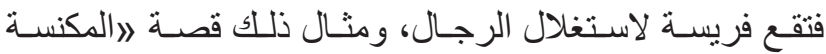

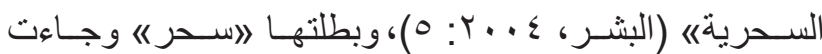

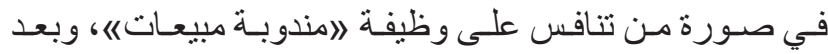
ذرف الدمـوع تحصـل عليها، و عليهـا أن تتجـول بيـن المنــازل

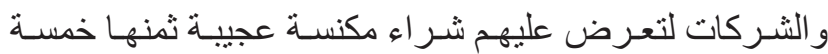

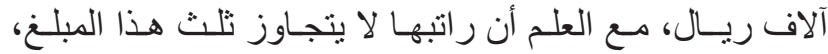

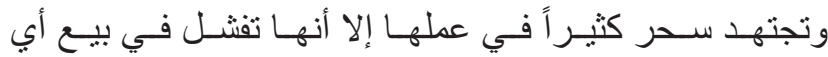

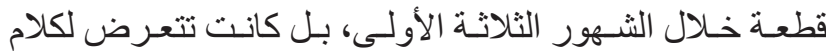

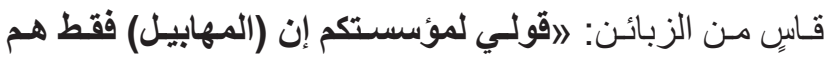

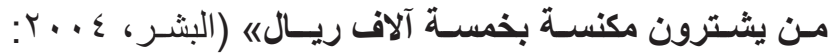

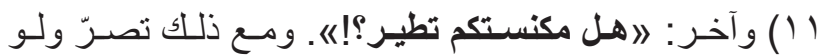

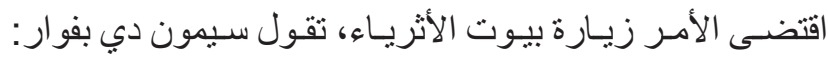

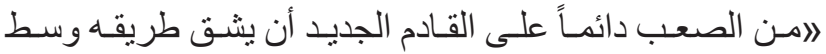

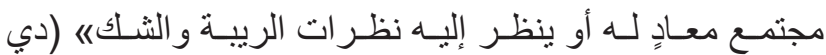

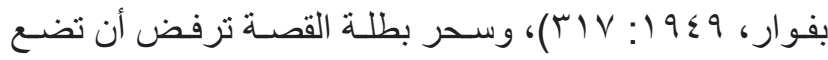

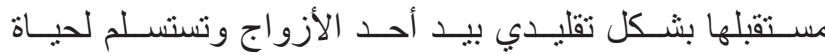

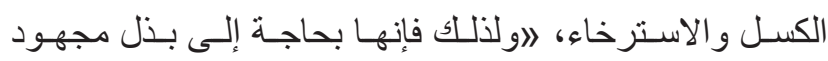

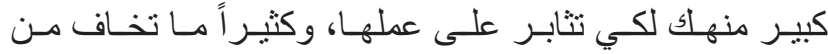

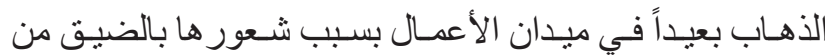

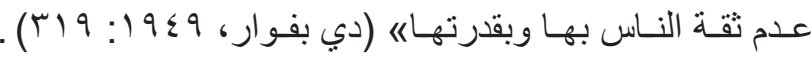

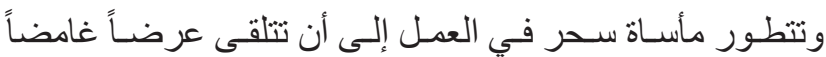

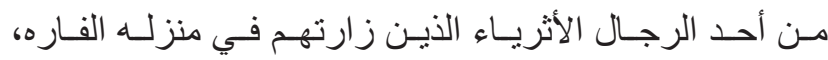

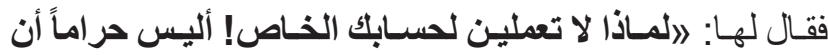

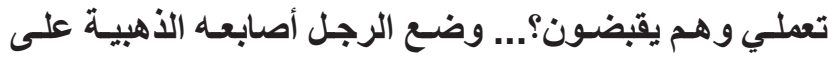
أصابعها التي رقدت على طاولـة المكتب بحنـان، فسـبتها،

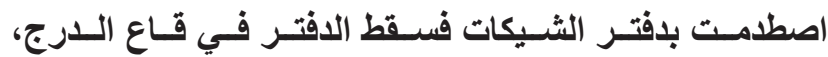

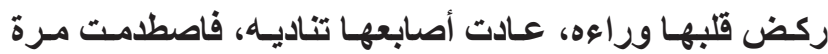

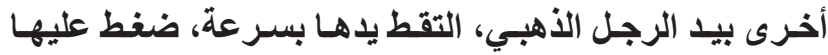

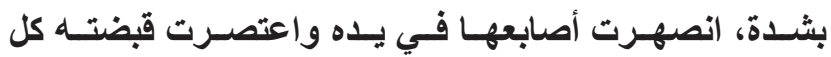

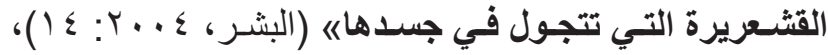

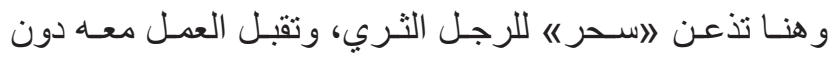

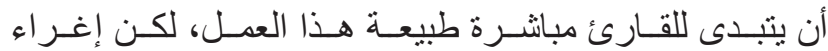

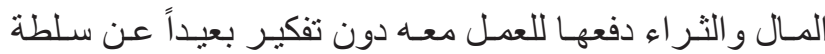

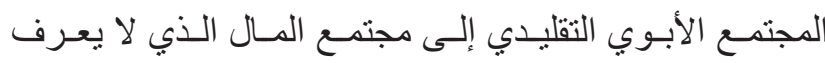

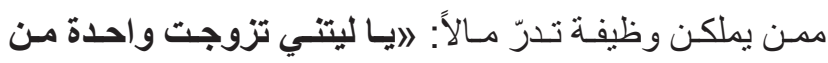

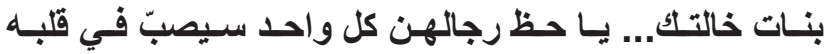

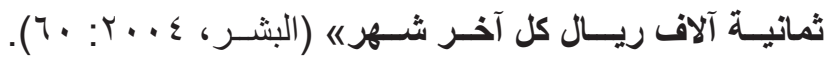

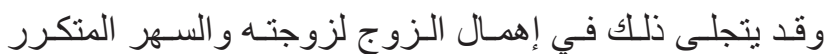

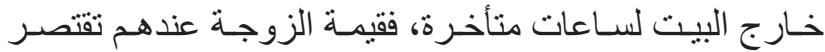

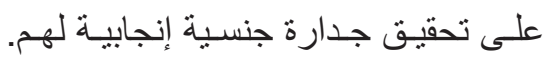

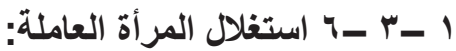

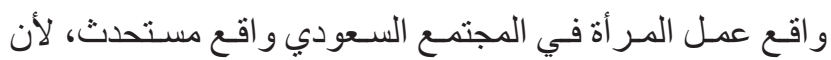

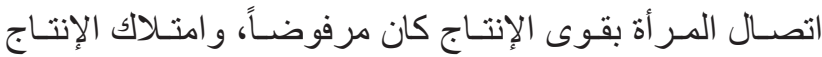

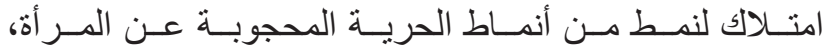

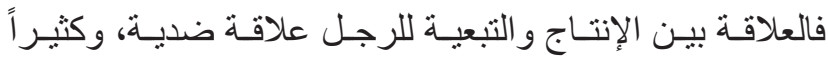

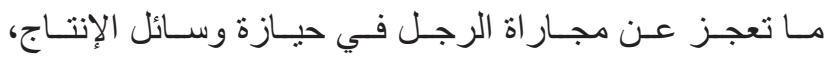

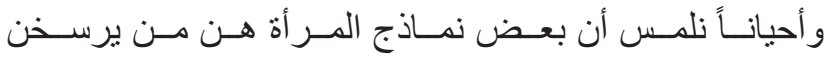

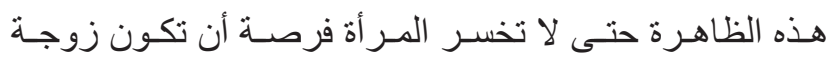

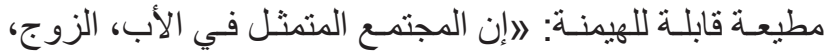

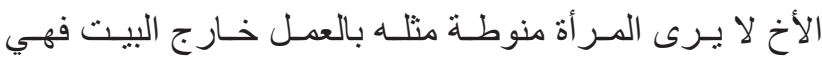

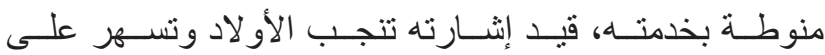

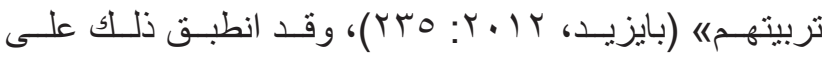

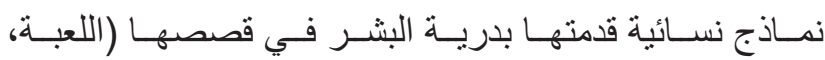

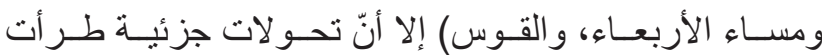

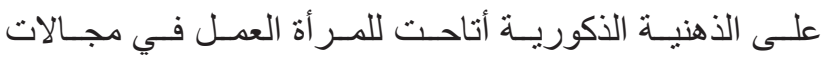

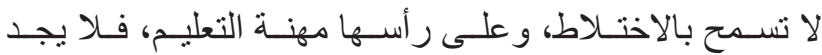

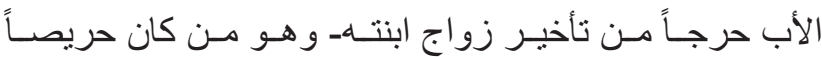

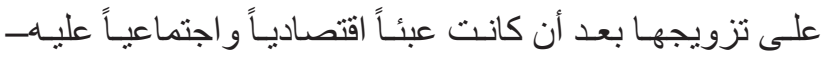
للاستفادة مـن إنتاجهـا ولو تهددهـا شبح العنوسـة، ويظهر ذلاتك

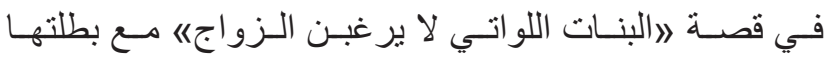

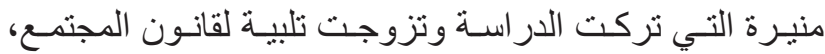

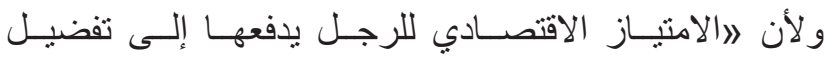

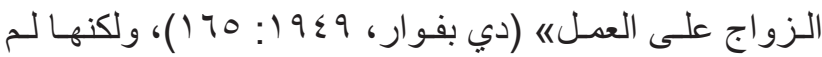

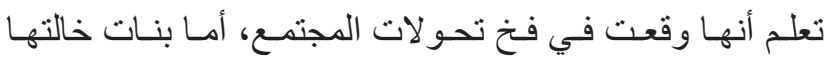

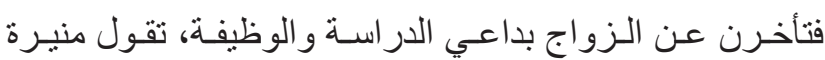

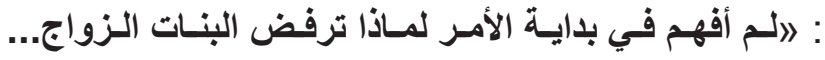

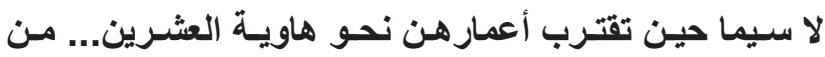

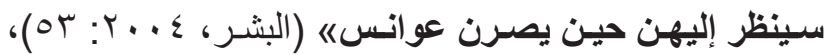

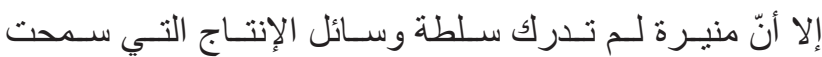

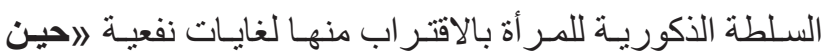

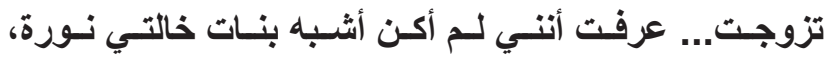

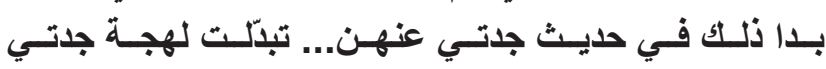

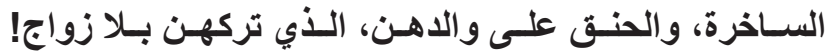

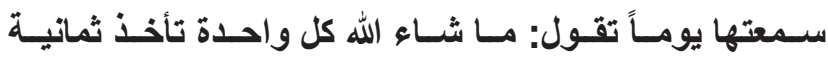

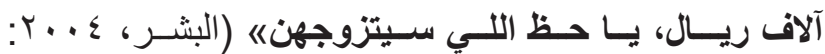




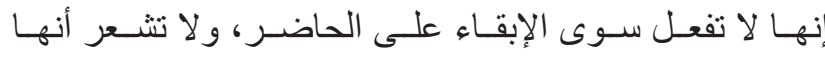

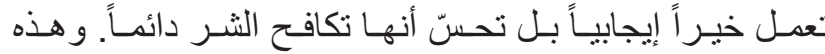

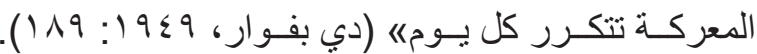

1 _ _ _ الإصرار على نمطية تفكير المرأة وإثبات تفوق الرجل: يقول جـول لافورغ: لالا تربطنـا بالمـر أة أبـداً رابطـة الأخـوة.

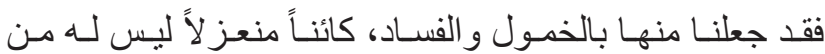

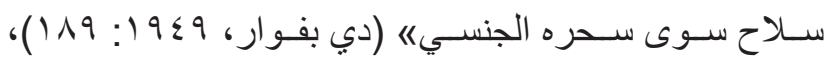

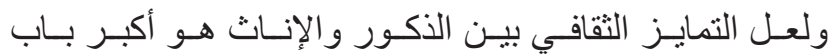

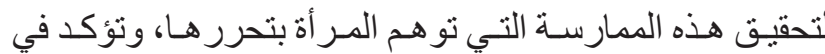

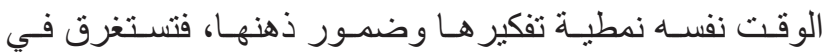

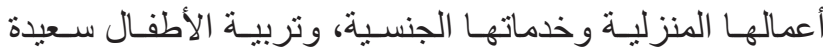

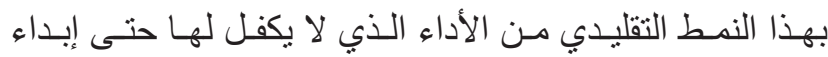

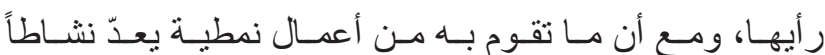

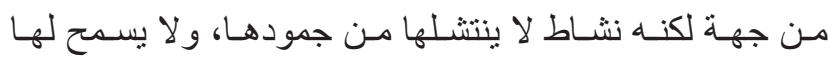

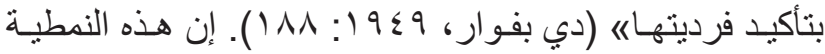

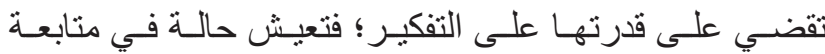

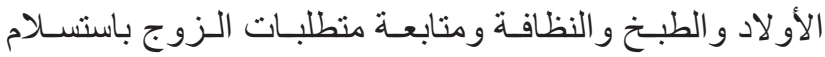

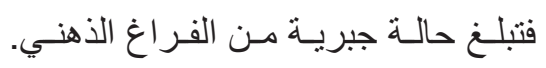

وقد قـادت هذه الممارسـة إلـى تأطيـر ذهنيـة المـر أة في نسق

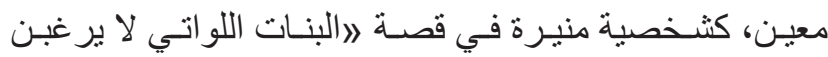

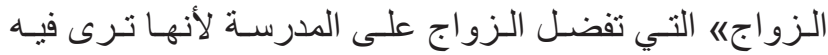

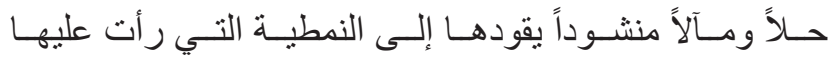

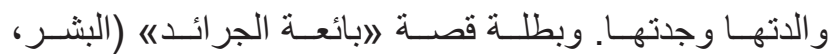

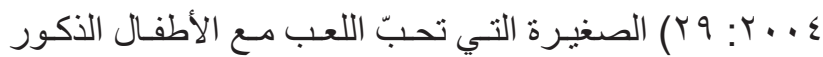

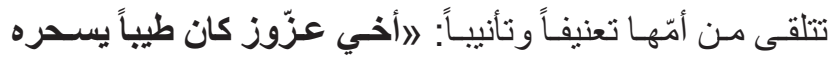

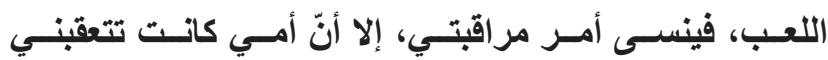

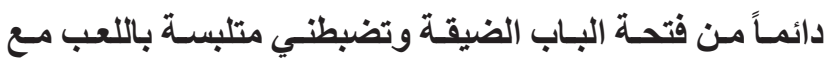

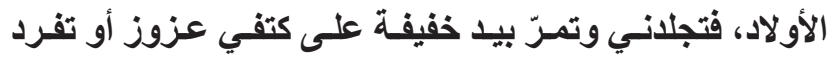

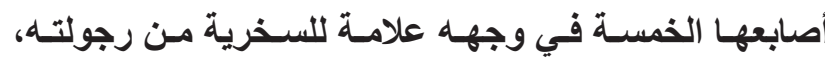

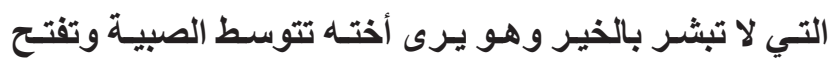

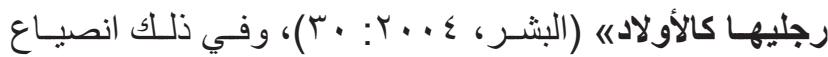

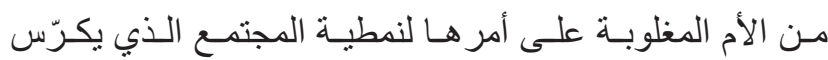

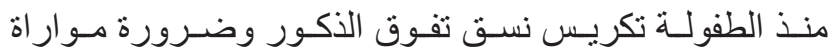

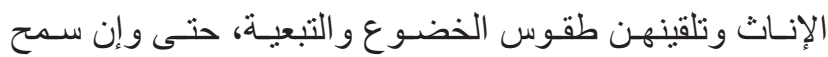

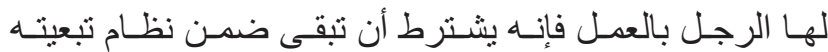

المحصّن اجتماعبـاً.

حتى وإن بلغتت المـر أة مرتبـة رفيعـة في عمهـا كطبيبـة منـلاً

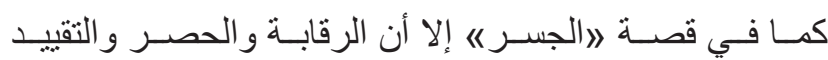

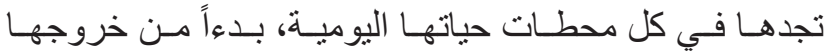

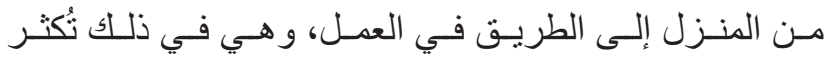

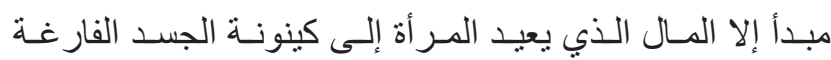

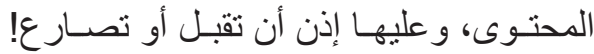

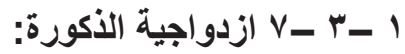

ويعـدّ تناقض الرجـل في تصرفـهـ وازدو اجيتـهـ مـن الملامـح

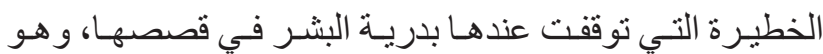

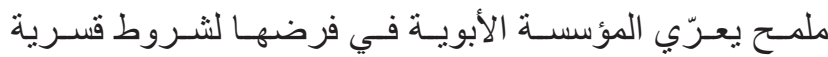

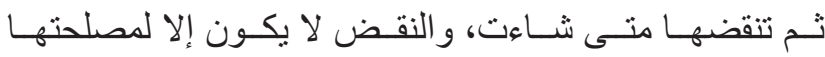

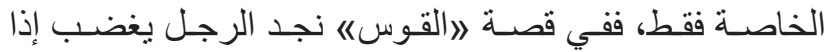

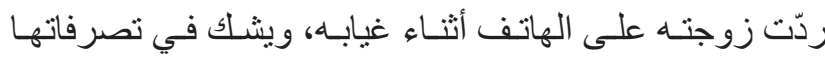

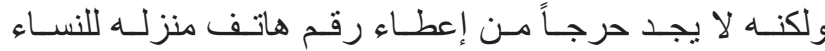

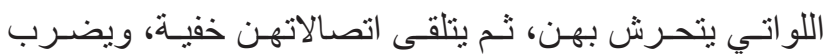

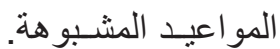

وتتكرر المسـألة على نحو أكثر خطورة في قصـة لاكاميرة

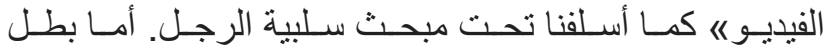

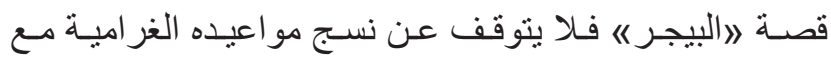

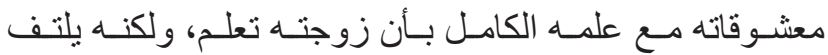

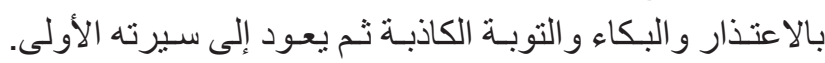
وفـي قصتــي 》الذيـبـه و القـوسه نطـرح بدريــة البشـر

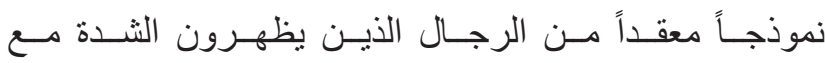

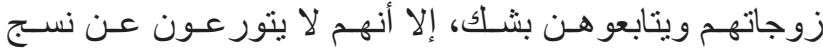

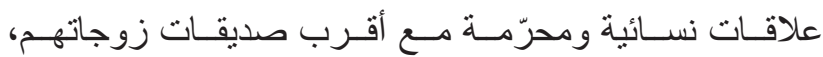

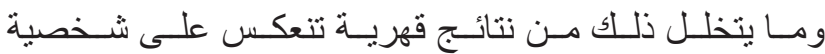

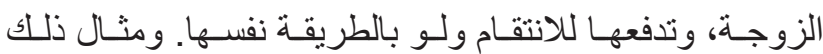

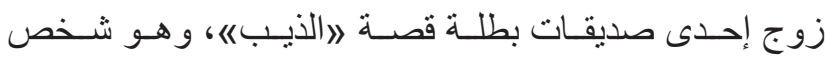

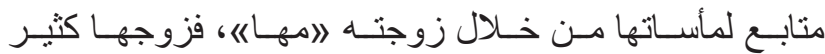

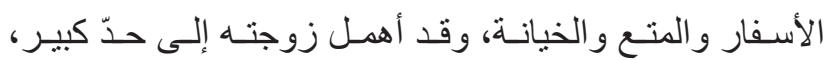

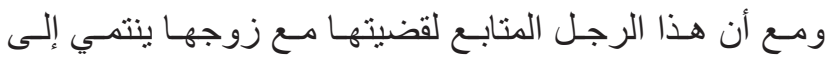

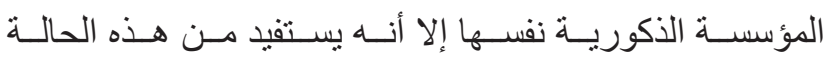

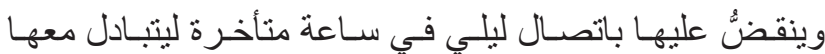

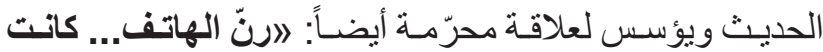

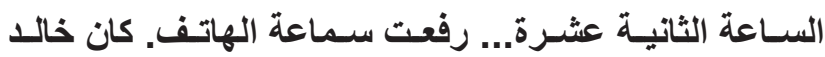

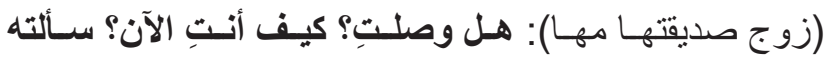

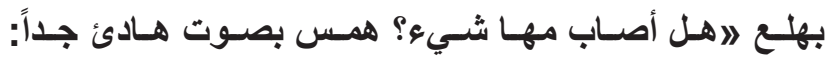

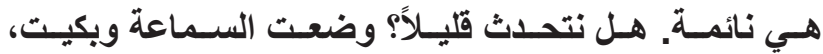

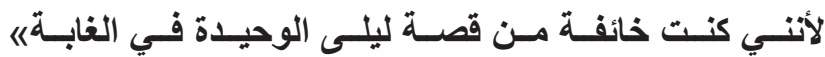

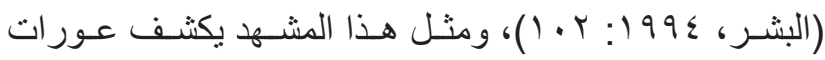

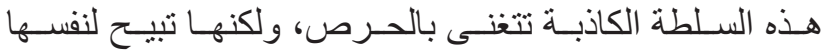

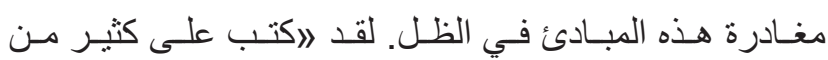
النسـاء في العالم التعـب الدائم المتكرر في معركـة لا تـؤدي إلى انتصـار ـ إن نفس المـر أة تـذوب و هـي تمشـي في مكانهـا. 


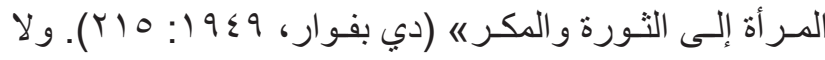

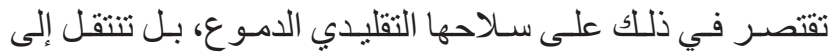
أدوار أكثر فاعليـة، بـدءاً مـن تقديـم شـخصيات أنثويـة جاذبـة،

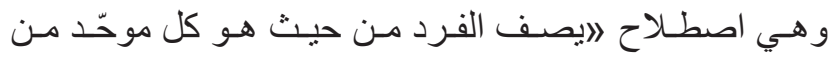

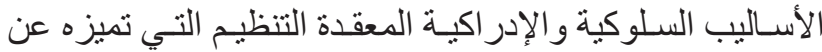

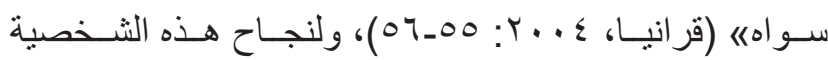

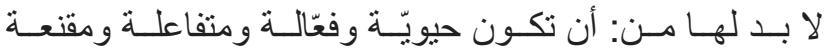

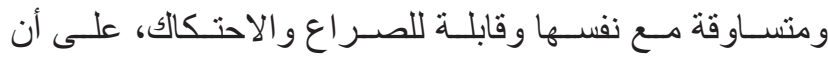

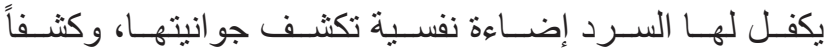

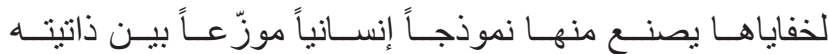

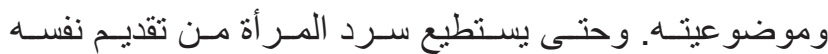
عليـه أن ينفتح نحـو الوعـي الكامـل بكينونتهـ مقفـلاً البـاب أمسام

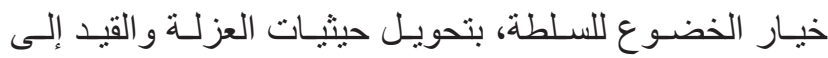

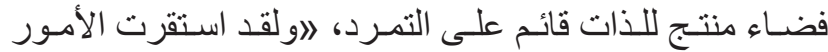
على أن الفرد الذي يخالف قاعدة تفرضهـا العـادات و التقاليد

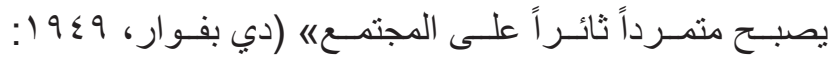

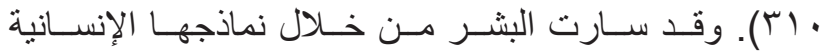

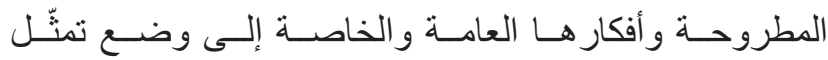

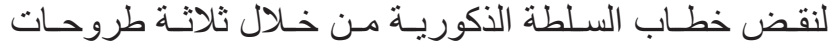

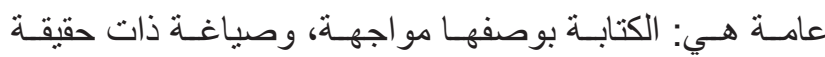
للأنثىى، وتعريـة الذكـورة وتهميشـها:

\section{r - الكتابة بوصفها فعل مواجهة:}

يقـوم الأدب النسـوي فيمـا يقـوم عليـهـ علــ إنشــاء كتابــة

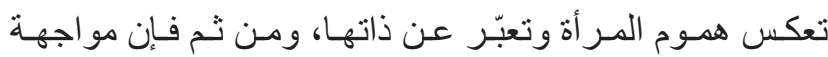

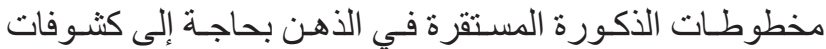

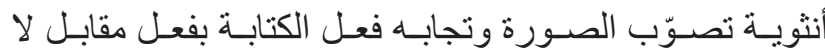
يقل عنسه حضـوراً.

وقد لخّصـت فرجينيـا وولف أهميـة الفعـل الكتابـي لـى المـر أة

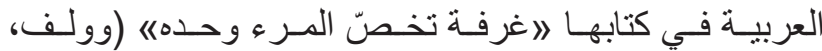

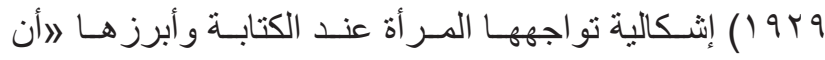

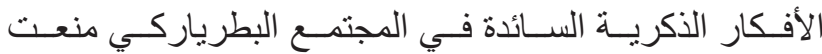

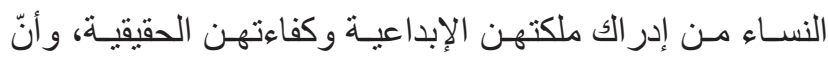

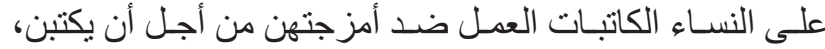

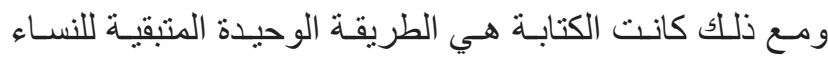

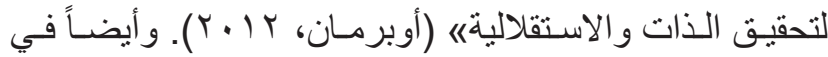

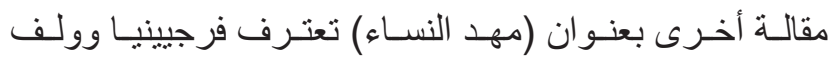

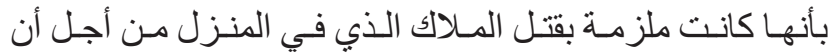

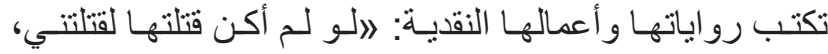

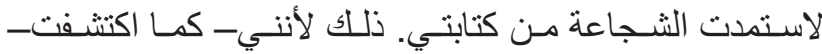

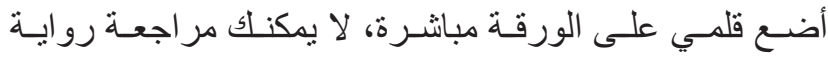

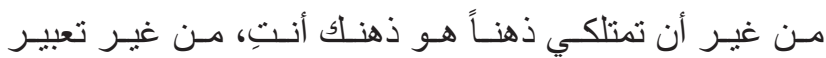

مـن إيـر اد ألفـاظ تـدل على تقييدهـا ور غبـة حذرة في تجـاوز

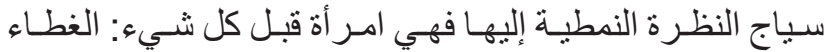

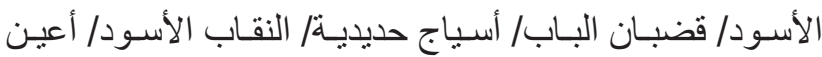

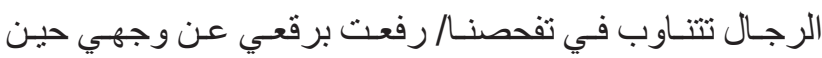

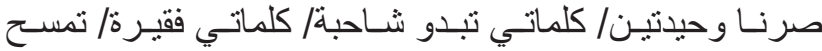

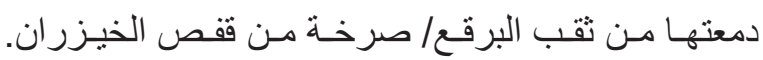

وبعد، فـإن تمثيـلات الذكورة التـي رصـدت الدر اسـة بعضهـا

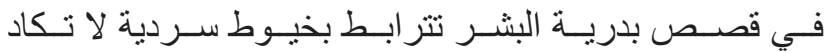

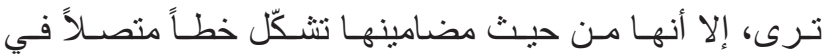

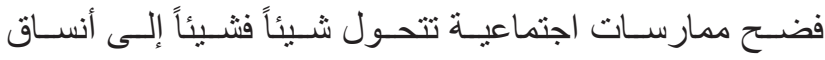

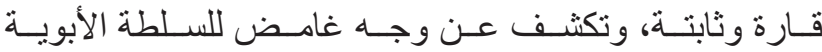

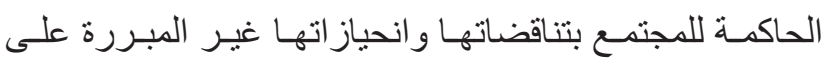

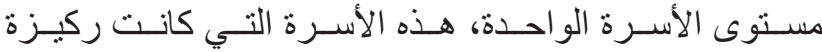

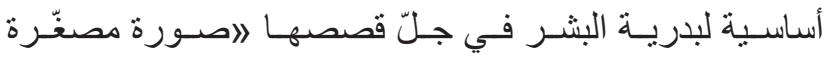

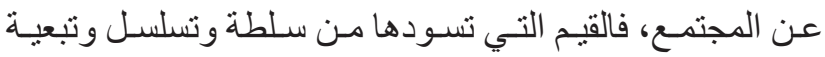

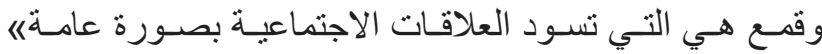

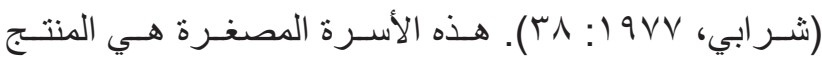

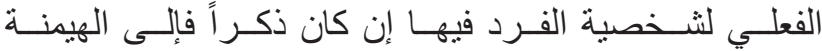

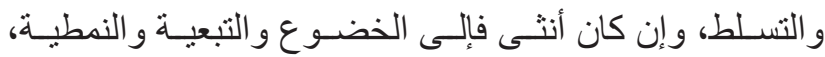

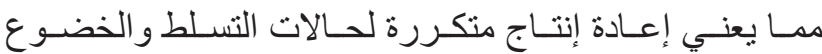

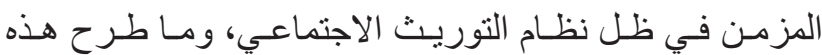

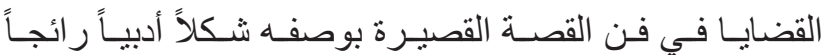

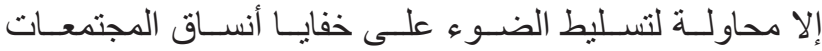

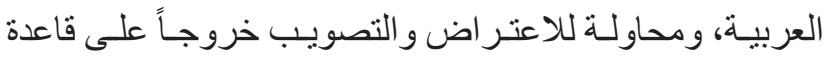

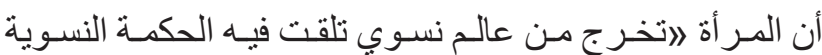

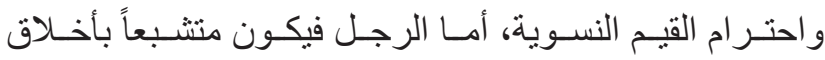

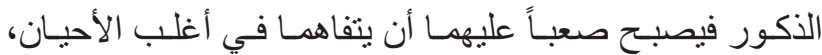

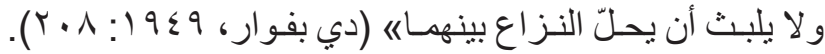

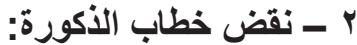

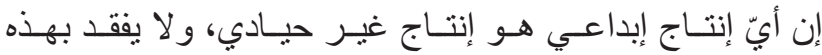

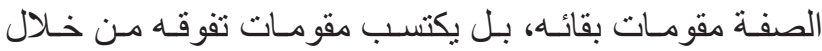

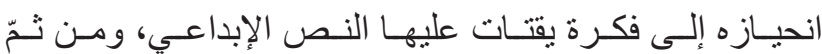

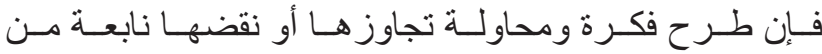

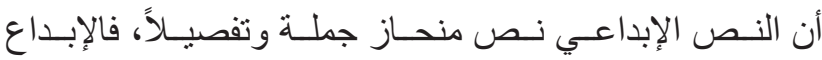

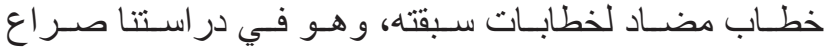
بيـن خطابيـن؛ الذكـورة و الأنوثـة.

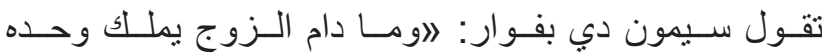

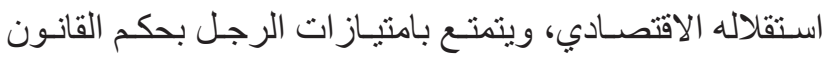

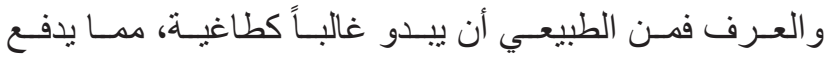


فانطلقـت ذات الكاتبــات ومنهـن بدريــة البشــر إلــى صياغــة

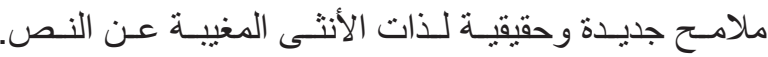

إن صناعـة ذات حقيقبـة للأنتخى أضحـى غايـة لهـن لمو اجهـة

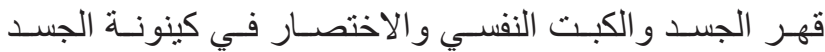

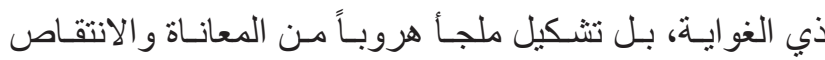

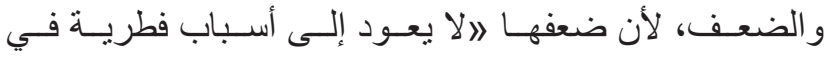

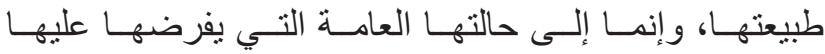

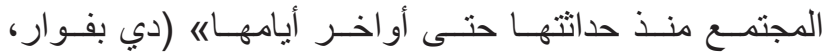

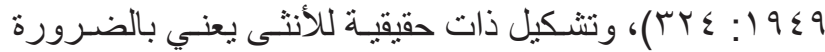

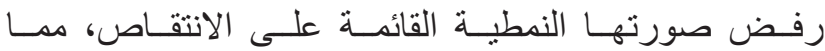

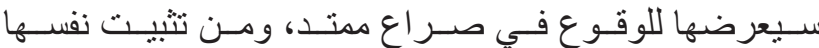

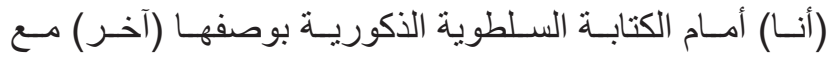
أنهـا سـتجد المقاومسة مـن داخـل (الأنـا) ومـن نمـاذج نسـائية لا لاعل تتـورع بفعـل الاعتيـاد وتسـبّد النسـق الثقافي على دعم سـلطة الذكـور وتبريـر أخطائهـم، يقـول عـزّ الديـن إسـماعيل: لالأم تسـتوعب في أغلب الأحسو ال كل المـوروث الثقافي الذكوري أذئي

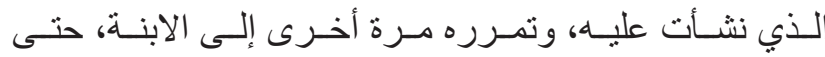

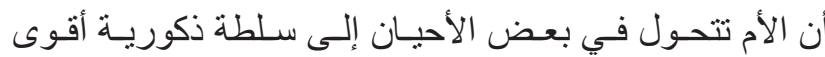

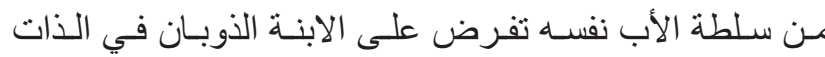

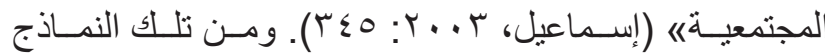

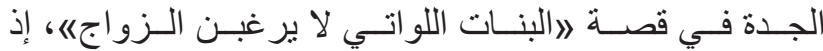

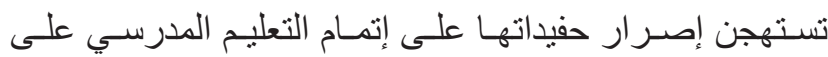
الـزواج وتهدد: 》مسن سينظر إليهن حين يصسرن عوانس؟)

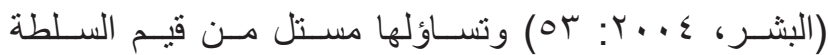

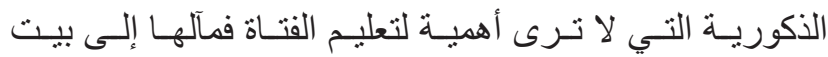
زوجهـا و التعليـم لا يزيدهــا إلا تمـردياً.

يضـاف إلى ذلك نمـوذج الخالـة في قصـة /السـطحس (البشـر،

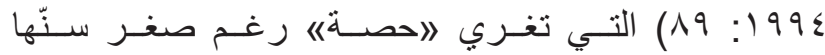

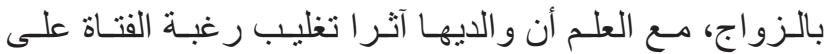

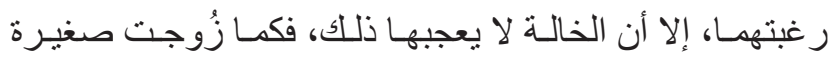
فعلى الفتـاة أن تحـذو حذوهـا.

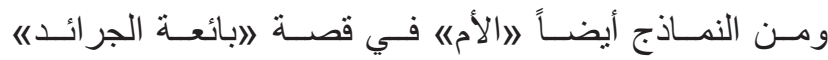

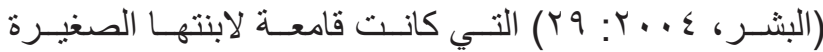

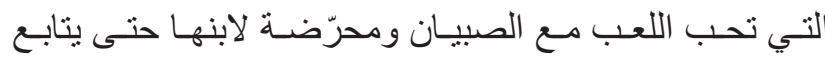

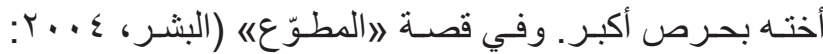

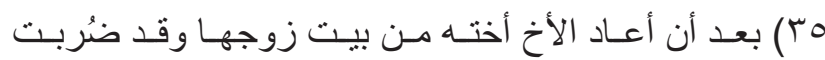
وحرمست مـن أبنائهـا دخلت في حالـة نفسية صعبـة، و أعطاهـا الطبيـب دواه، إلا أن الأم تخلصــت منـه، مكتفيـة بقر اعة الثـيخ

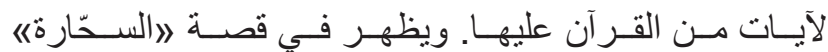

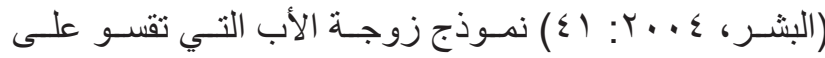

عمـا تعتقدينــه الحقيقـة بشـأن العلاقـات الإنســانية؛ الأخــلاق، الجنس. وكل هـذه المسـائل طبقاً للمـلاك الـذي في المنـزل لا

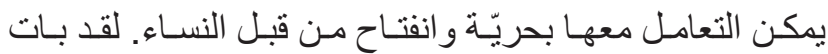

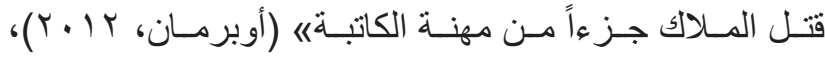

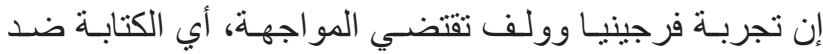

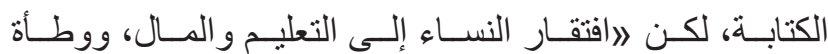
القيـود الفكريسة التهي يخضعـن لهـا، يولـد لديهـن إحساسـاً بعـدم

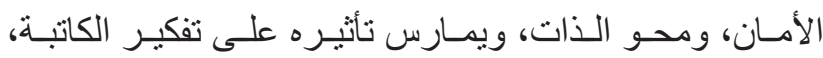

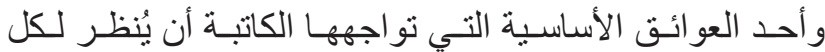

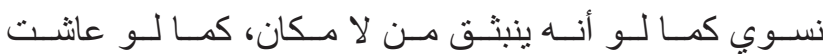

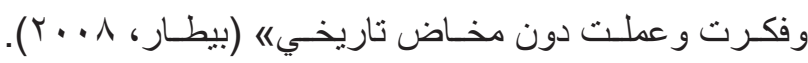
وقـد ركّززت بدريـة البشـر أيمـا تركيـز في خطابهـا القصصـي على محاولـة اسـتجلاء خطـاب مغايـر تفتـرق فيـهـ مـع الآخـر

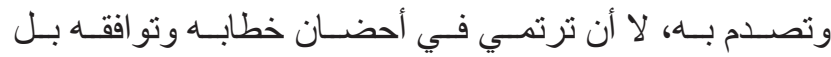

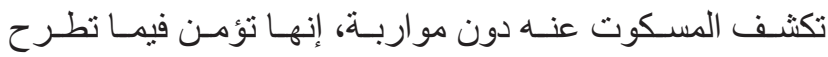

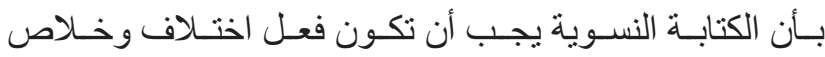

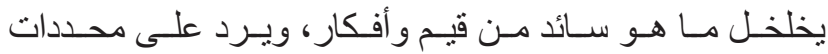
القهر الوجـودي الـذي فرضتــه الكتابـة الذكوريـة الممجدة لسـلطة المجتمـع و الأب و الـزوج و الأخ تخـرج ذات ذات المـر أة مـن منطقة

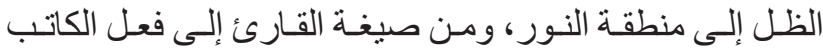

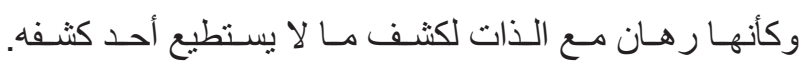
إن بدريـة البشـر فيمـا طرحتهـه مـن تمثيـلات خطيـرة للذكـورة

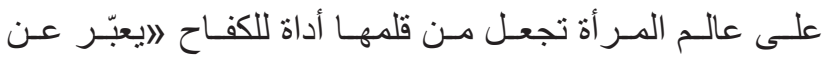

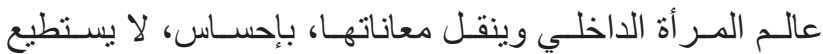

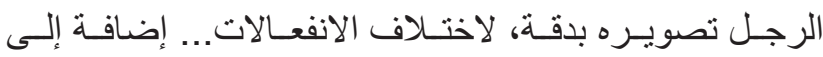

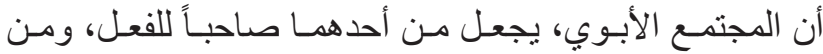

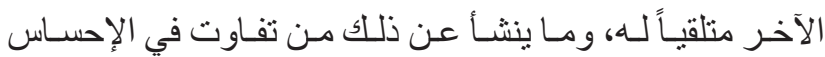

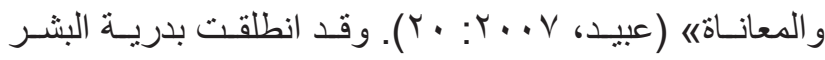

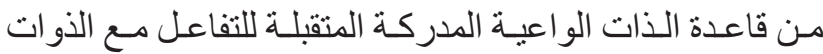

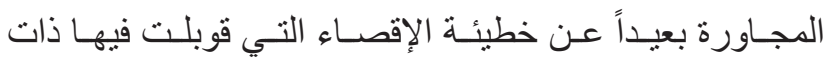

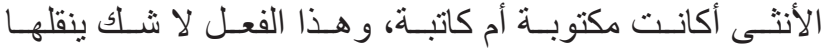

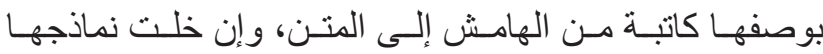

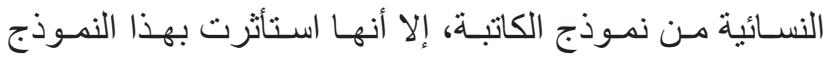
في شـخصها وفي كتاباتهـا المصـرّة على مجابهــة فعـل الكتابـة

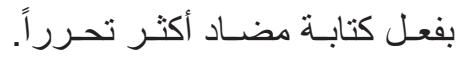

\section{r r r r r r باغة ذات حقيقية للأنثى:}

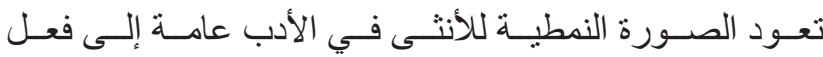
ذكـوري صـرف رسـم الأنتى وسـوق ملامحهـا، وأسـهم ذلك في في

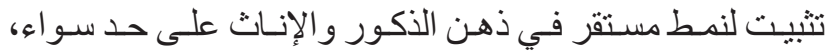

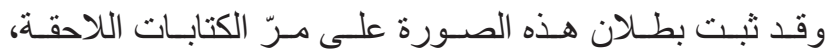


مرهـــ مـؤوّل يصـف الآخـر دون أن يتعـدى عليـه، فبطلــة

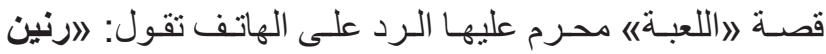

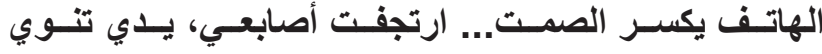

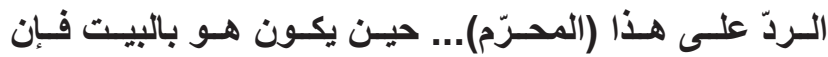

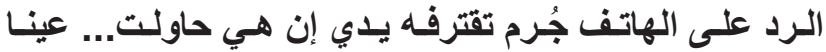

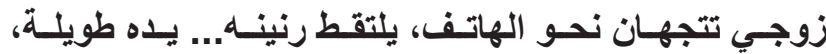

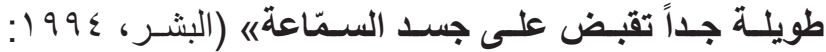

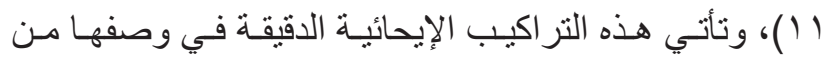

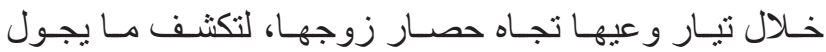
بخاطر هـا تجـاه هذه الممارسـات، وقد حققت طريقـة استبطان الثـخصبات الأنثويـة لإعطائهـا المجـال ورقياً لكثـف مكنونهـا

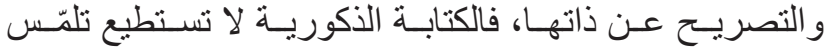

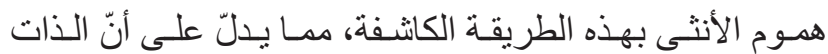

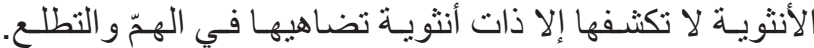

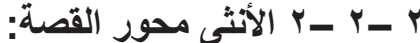

وقـد تقصـدّت البشـر في جميـع قصصهــا القصيـرة أن تجعـل

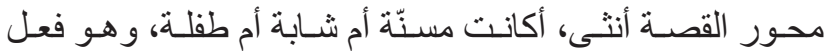

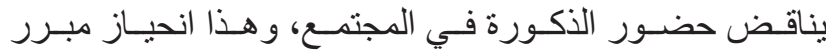

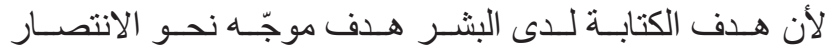

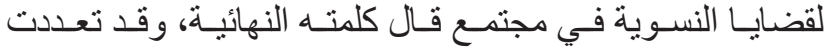
نمذجـات الأنثى في قصصهـا، وجـاء على رأسـها هموم المـر أة المنزوجـة فـي قصـص مـن قبيـل: لاراللعبـة، القـوس، كاميـرة

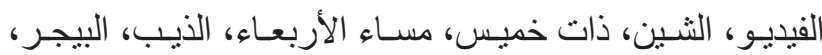

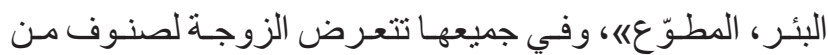
العنـت مـع أزو اجهن بـدهاً مـن السلبية مـروراً بالخيانــة وانتهاءً

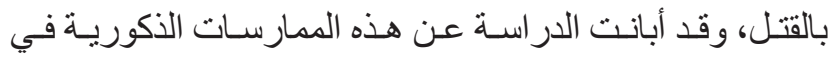

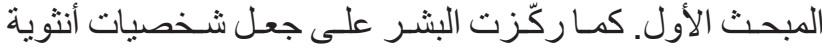

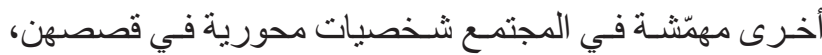

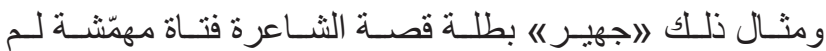

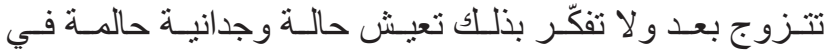

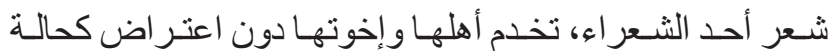
كثير مـن الفتيـات اللواتـي ينتظرن في بيـوت أهلهـن، و عندمـا

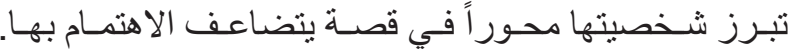

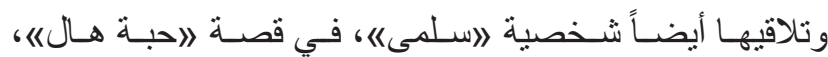

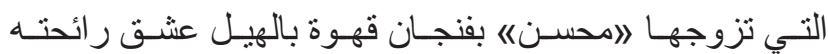

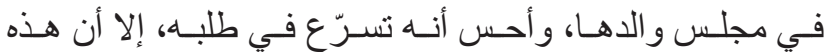
البدويـة التـي تشـبه حبـة الهيـل تتحول مـن شـصية منسية إلىى

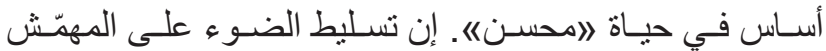

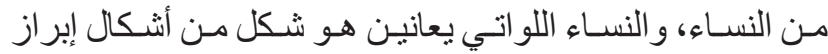

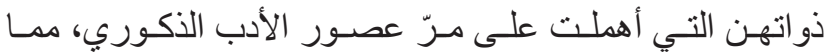
جعل أدب البشـر مـن الأدب الملتـزم بقضايــا النسـوية.
وحيـدة زوجهـا لـو لا وجـود عمنهـا في بيــت مجـاور لبيتهـا

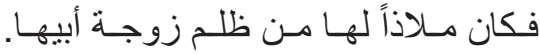

وبدريـة في كثـفها هـذا لرمسوز مهمـة في مجتمـع الإنساث

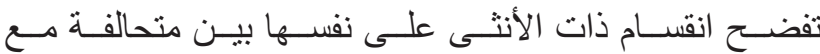

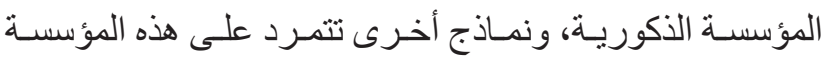

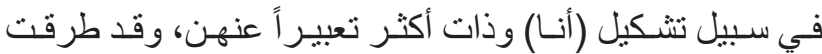
البِشـر في ذلـك سـبلاً شـنى، منهـا:

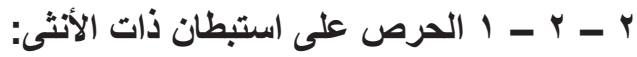
إن الثـخصية الأنثويـة التـي حرصـت البشـر على اسـتبطانها

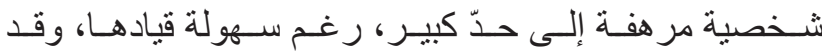

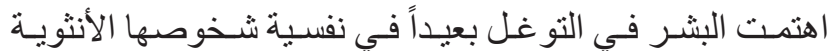

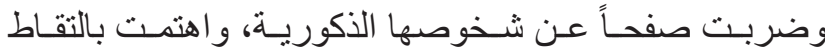

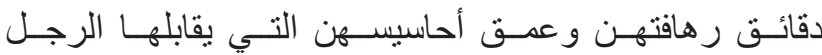

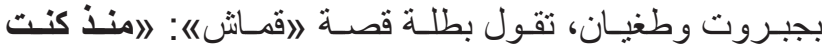

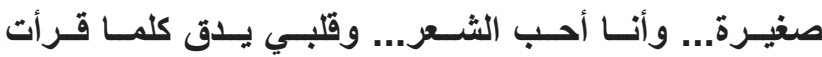

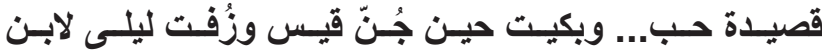

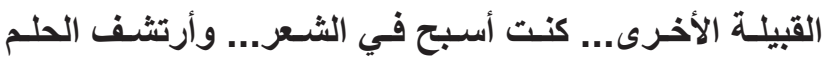

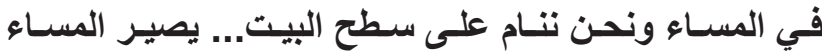
صفحسة زرقـاء كلــون البحـر... والقهـر كرسـي ومصبـاح

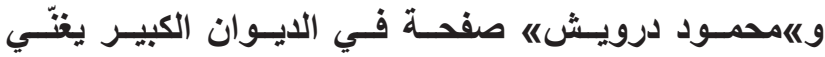

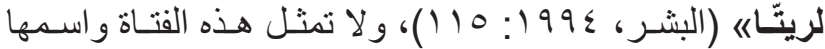

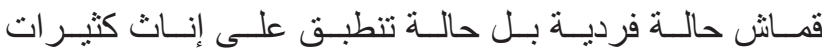

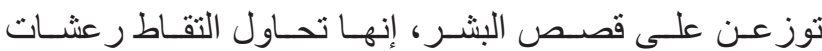
الحبـاة الإنسـانية الدافئة لهـن، لتؤكد إنهـن يصـدرن دون عُقدـ.

أمـا بطلـة قصـة 》الشـبهاه التـي تذعن دون اعتـر اض على نبـأ

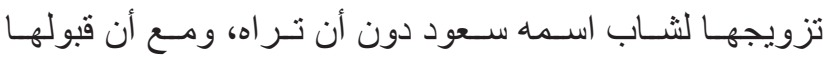

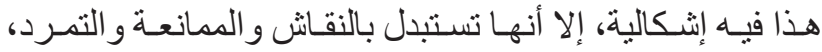

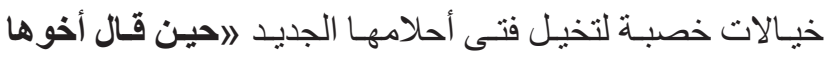

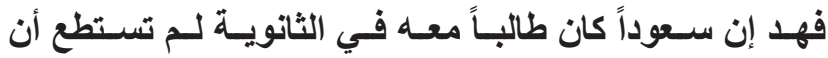
تتخيل إلا أن سعوداً يشبه فهـ، ثيابه نظيفة وشساربه كثيف...

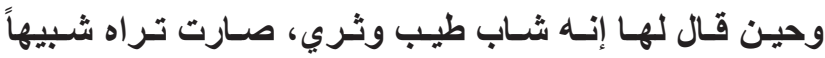

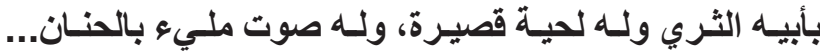

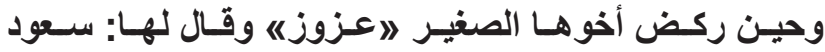

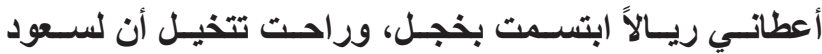
غمازتيـن تغـزان على وجنتيـه كلمسا غرق في الضحكـ....

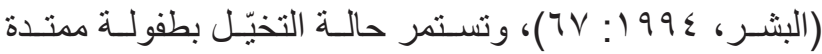

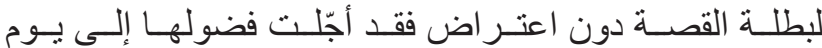

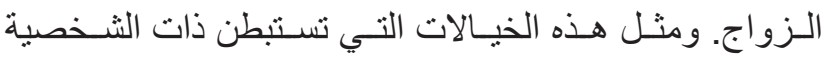
لتكثـف أناقـة إنسـانية ترفل بهـا هذه الثـخصيات، وفي بعض التض

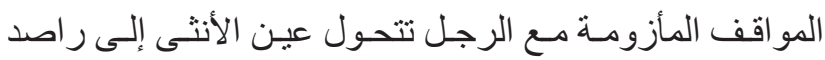




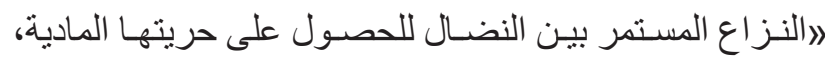

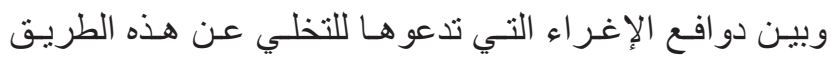

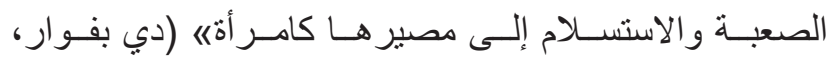

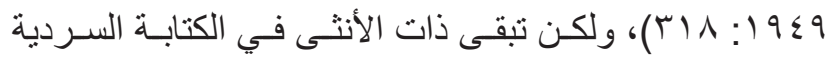

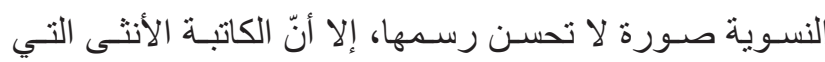

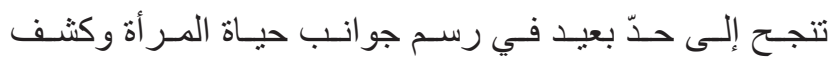

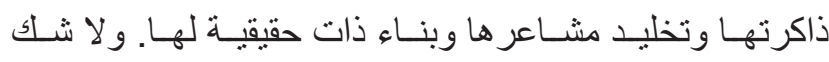

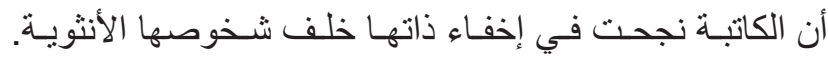

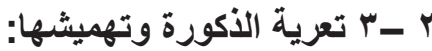

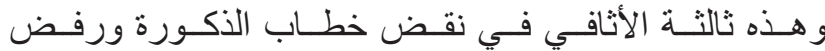

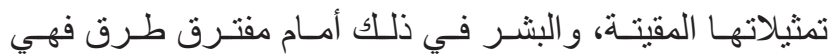

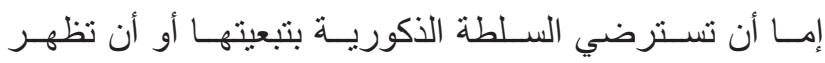

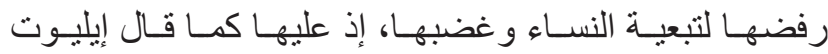

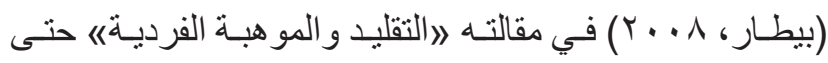
يكون الفنـان أكثر كمـالاً عليهه أن ينفصـل في داخلـه الإنسـان

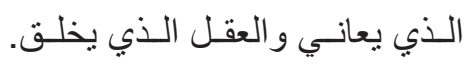

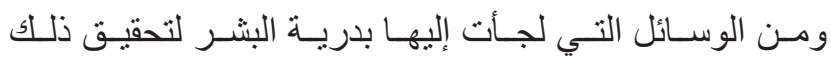

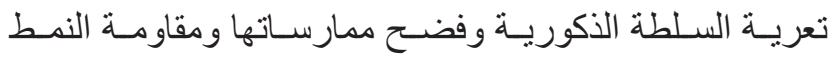

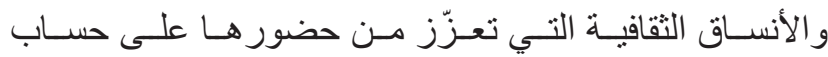

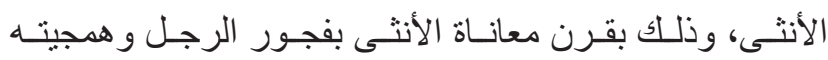

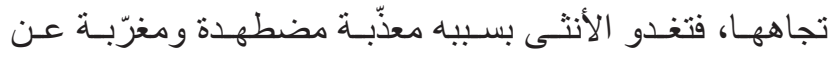

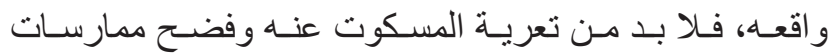

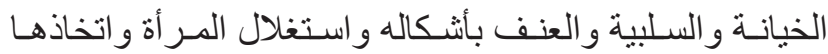

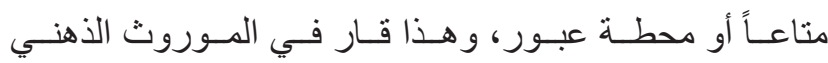

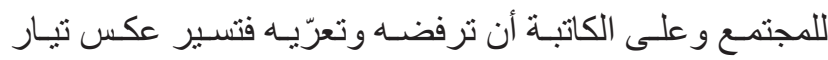

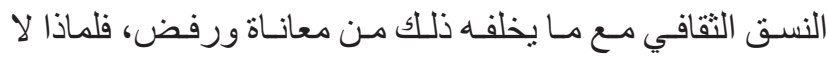

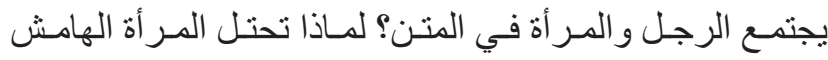

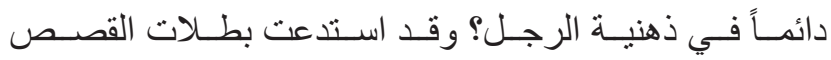

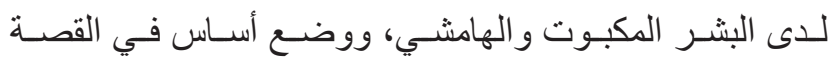

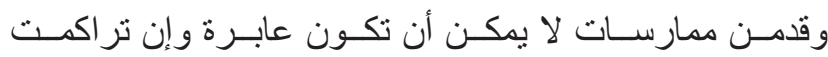

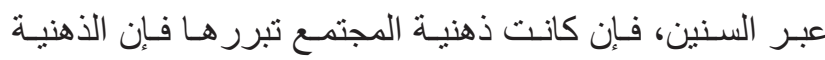

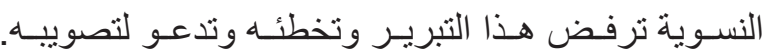

لقد نجحت الكاتبـة في قصصهـا في اغتيـال رمزي لحضـور

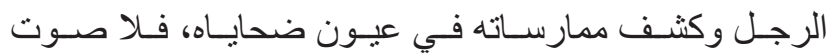

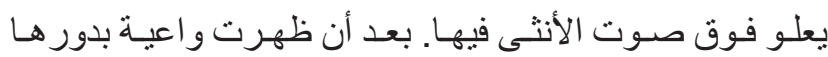
وبقضيتهـا مقابـل جلادهـا.

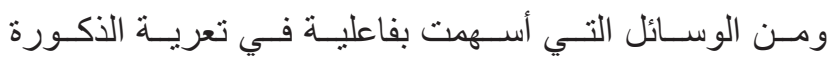

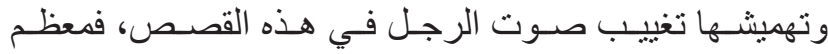

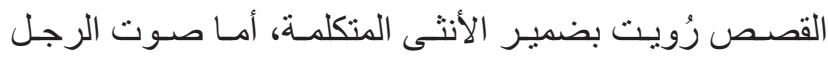

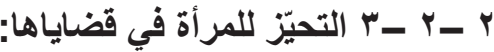

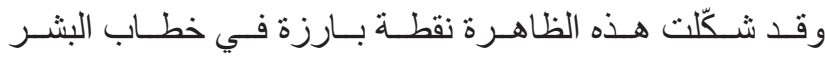

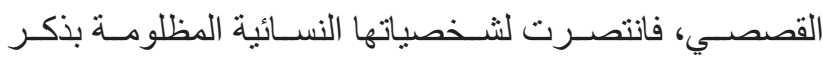

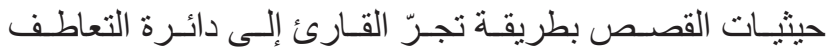
معهـن. كمـا أبرزتهـن عارفـات بممارسـات الذكـورة الخاطئسة

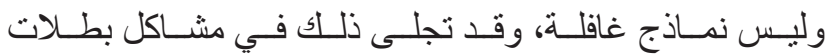

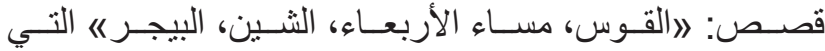
تحكي قصص خيانـة واضحسة لأزو اجهن، و هن يعلمـن ويثابرن

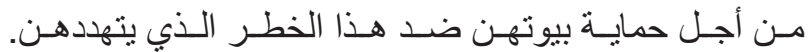

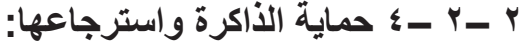

ومــن الملامسح البـارزة فـي صناعـة الـذات الأنثويـة حمايـة

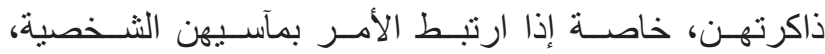

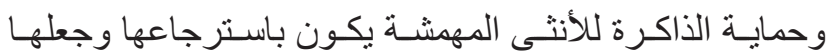

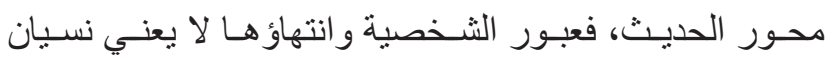

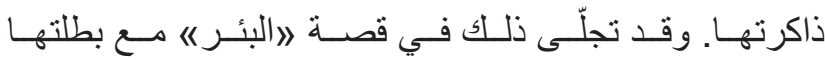

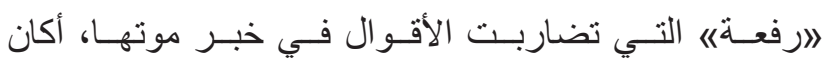

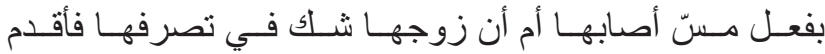

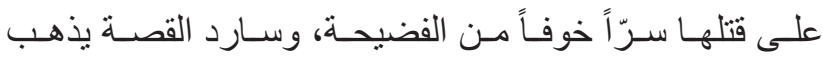

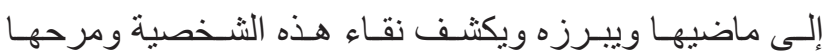

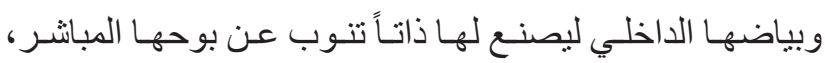

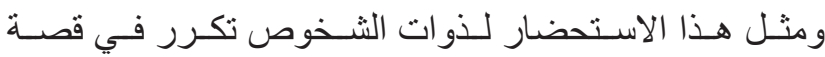
》المطوّ ع) وبطلتهـا 》منيرة)| التي تدخل في حالة نفسية بعد

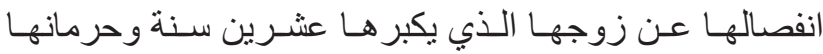

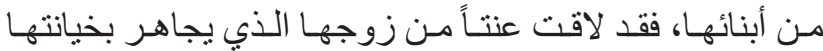

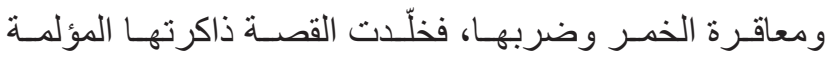
وثبتتهـا لنتســاءل عـن أي ذنـب أقدمـت عليـهـ.

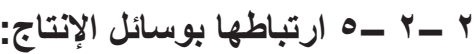

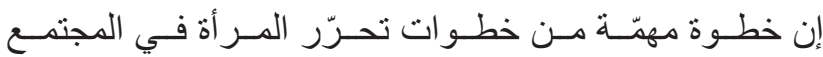

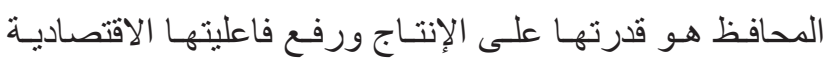
حتى لا تبقى رهنـاً لأعطيـات الززوج أو الأب، إلا أن شـخصية

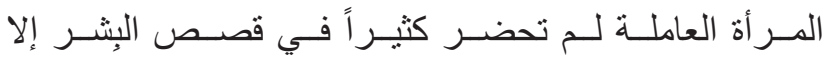

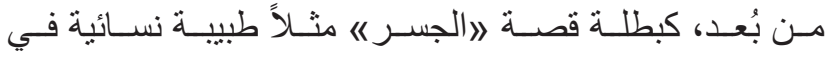

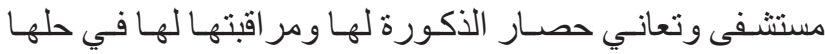

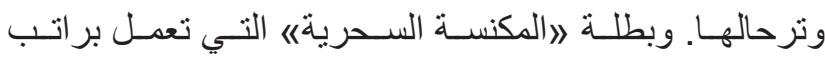

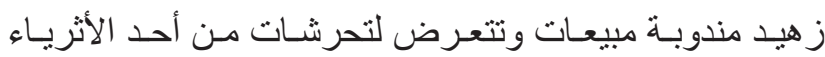

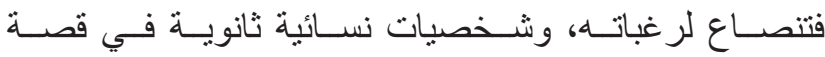

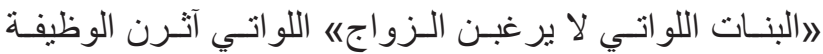

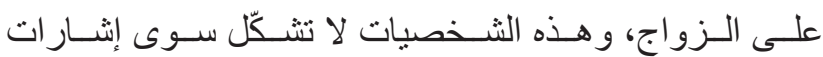

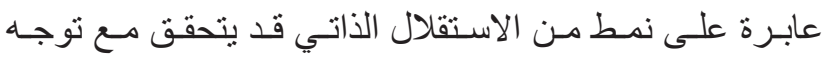

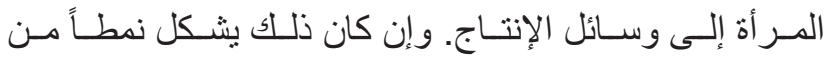


شـرطاً سـلطوياً، كمـا بـرز صبر الأنثى وصمتهـا حبـال سـلبها

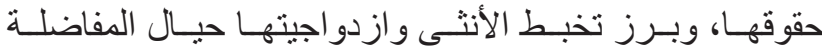
بيـن التعليم و الززواج. وتوقف الزمسن اليومسي بضبط السـاعة

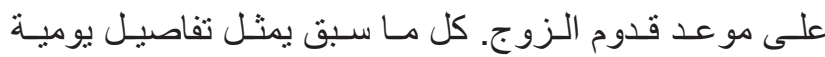
هامشـية فـي نظـر الرجـل الـذي تشــله العموميـات، ولكنهـا

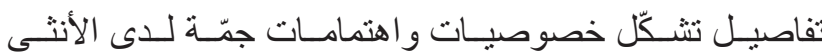
المستـغرقة في دقائق حياتهـا.

وقـد اسـتدعى الوقوف عند هذه التفاصيل التركيز على الرؤية

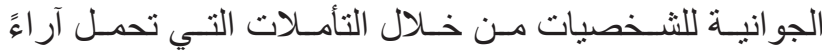

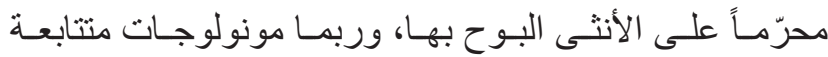

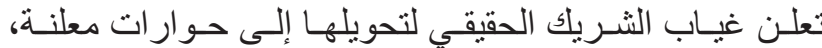

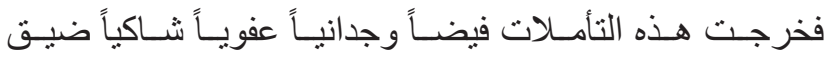

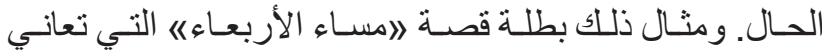

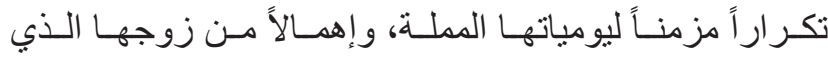

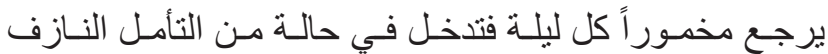

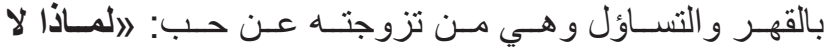

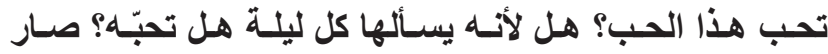

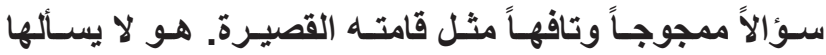

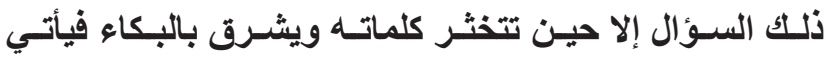

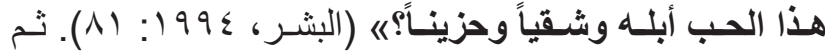

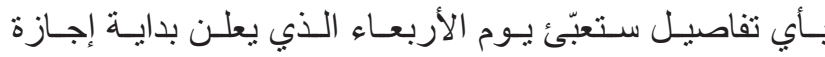

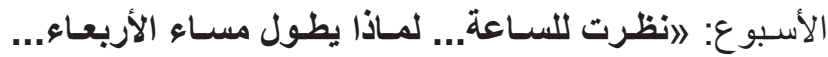

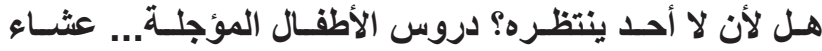

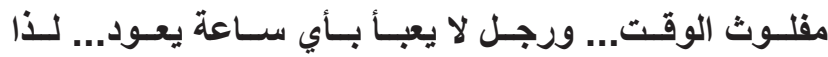
فـإن المســاء يطـول حيـن تغسـل صحسون العجيـنه (البشـر،

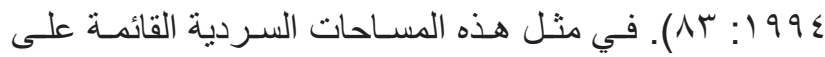

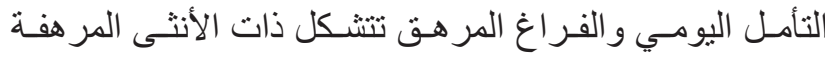

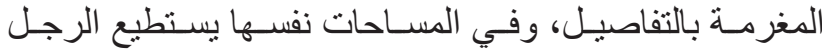

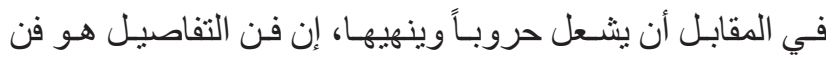

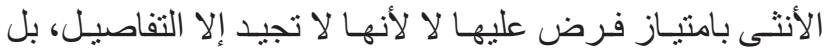

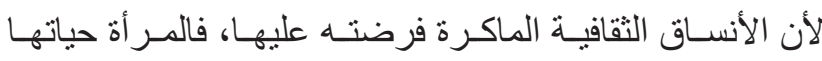

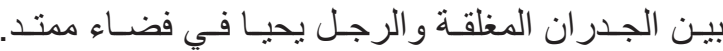

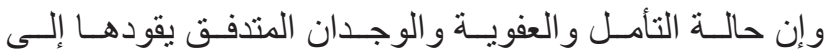
توظبـف الحلـم، فهـو مـلاذ للخـروج مـن الانغـلاق، ومثــال

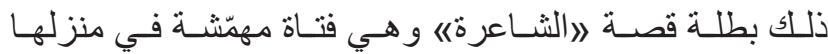

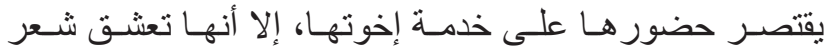

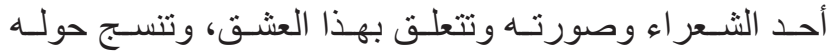
أحلامــاً تخفف عنهـا جبـروت الحيـاة اليوميـة القاسـية المليئسة

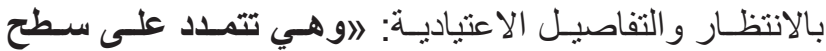

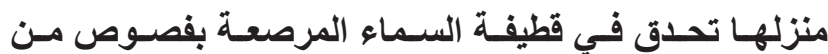

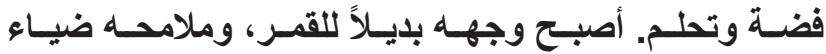

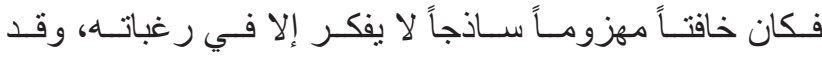
أضربـت سـاردات قصـص البثـر عـن الغـوص في نفسـية

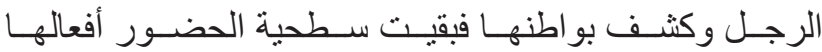

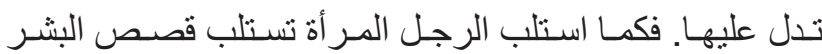
شـخصية الرجل سـردياً، وتتفرغ غلو لوصف مشـاعر شـخصياتها

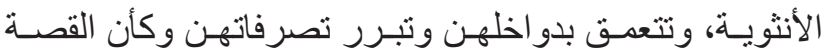
برمتهـا منبـر لهـن.

لقد قـاد ذللك إلى قتـل السـلطة الأبو ية رمزيـاً بتعريتها وتفريغها مـن مضمونهـا المحصدّن، وقتـل الأب رمزيـاً شكل مـن أثنكال

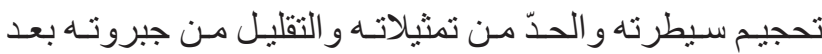

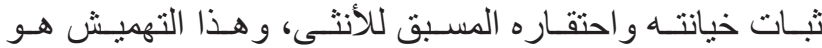

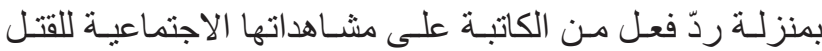
البومسي للأنثى ومصــادرة مكتسباتها الثـر عية و الإنسـانية. إلا أن نمـوذج المـر أة المثقفـة المتمـردة الناضجة كان لاى البشـر

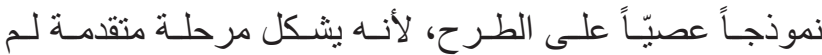

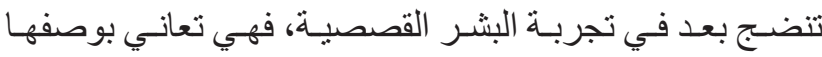
مثققة مـن سـلطة مجتمعهـا الأبوي في كثير مـن نشـاطاتها.

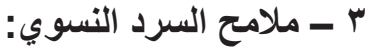

لـن يختص هــا المبحـث في جمع طاقـات السـرد المتوقعـة

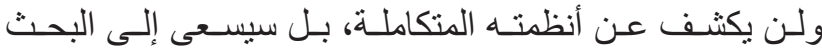

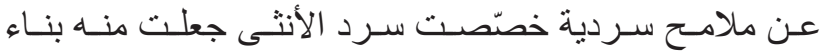

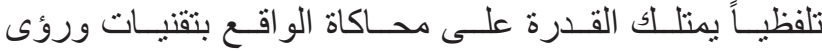

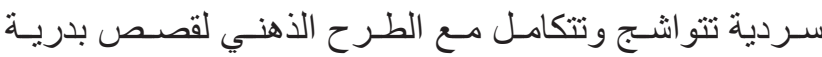

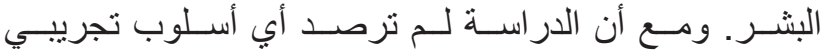

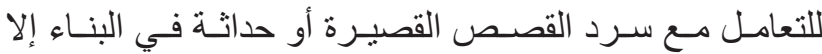

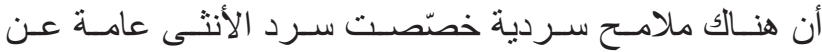

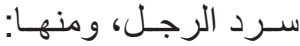

ب ـا الوقـوف عنــــ المسـكوت عنــه فـي الحيـاة اليوميـة

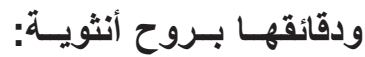

لقــد جـاءت أحـداث القصـص برؤيسـة أنثويـة خالصــة تتكامـل

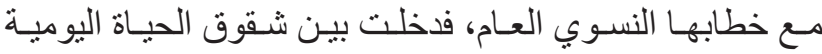

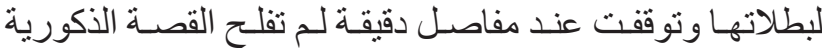
في النفـاذ إليها، متخذذة مـن ذات البطلـة الأنثى مركز أ لرؤيسة

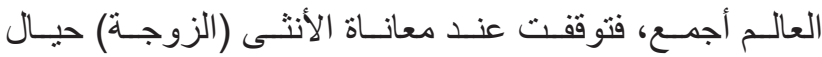

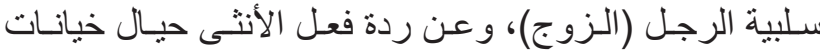

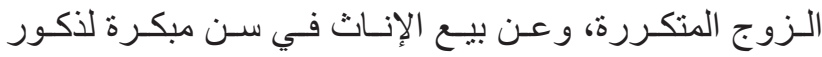

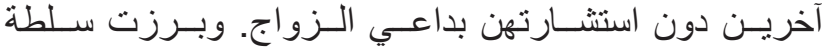

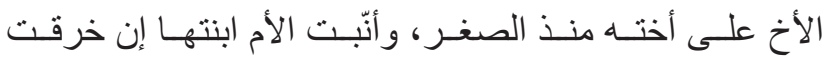


مـن تأنيـث نهايـات القصـص أيضـاً.

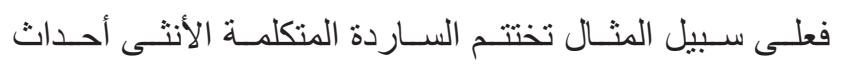

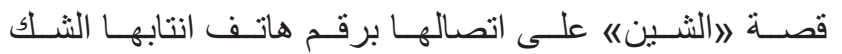

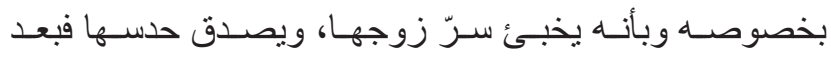

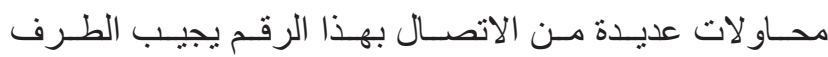

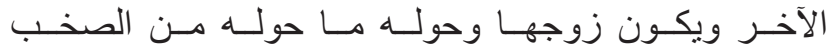

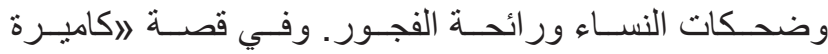

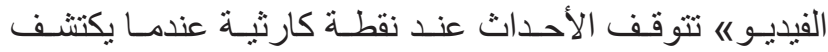

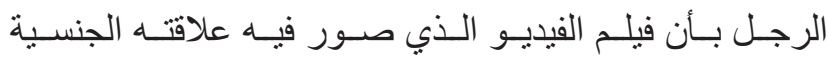

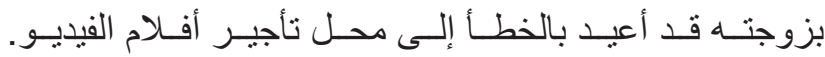

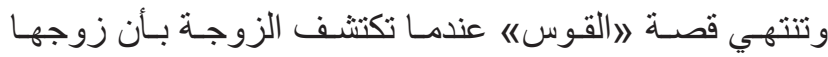

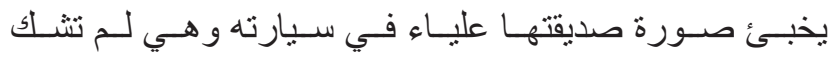

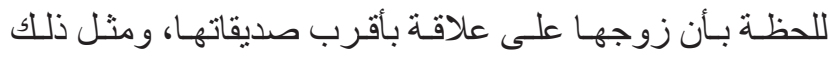

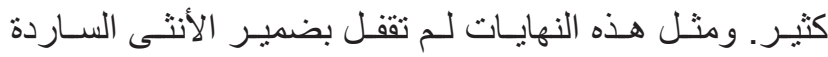

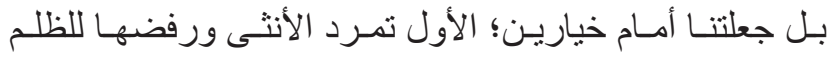

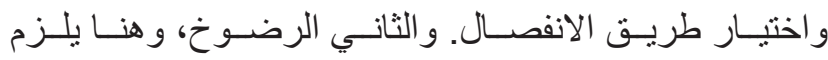

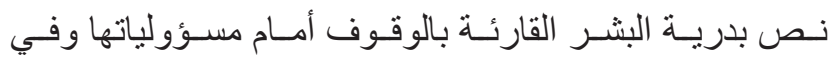

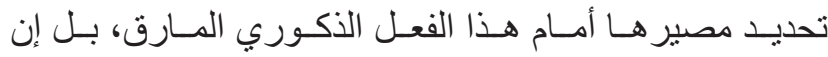

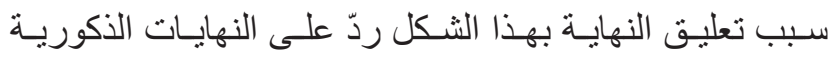
الحاسـمة التـي لا تقبـل التعليـق.

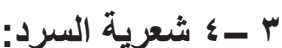

يـرى جاكبسـون أن الأدب لا يكون أدبـاً إلا عندمـا يحقق أدبيتهـ

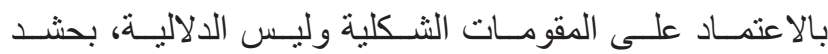

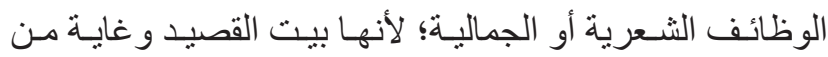

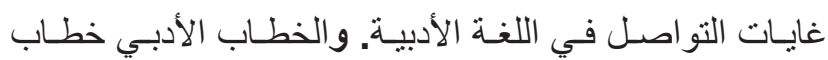

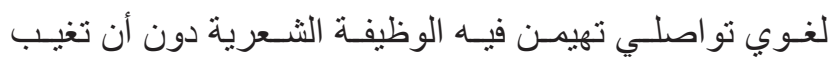

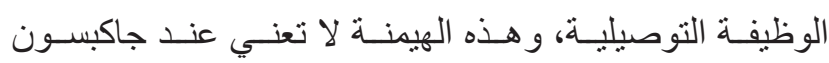

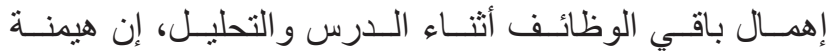

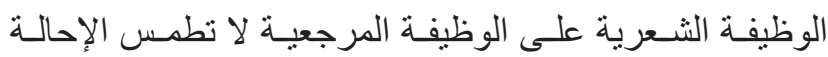

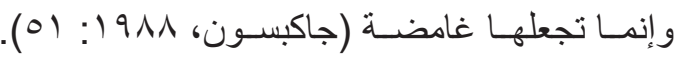

و الثـعرية خصيصـة سـردية حفـل بهـا خطـاب البِّــر

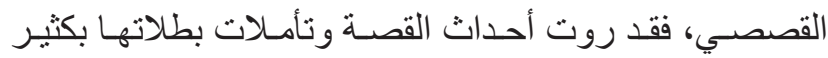

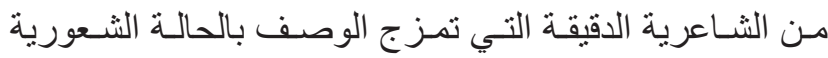

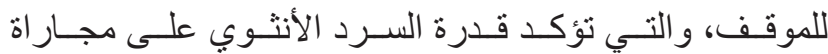

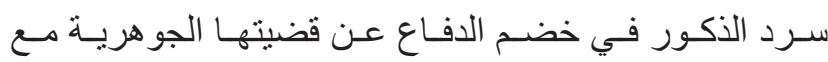

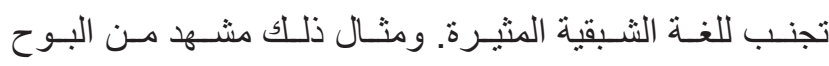

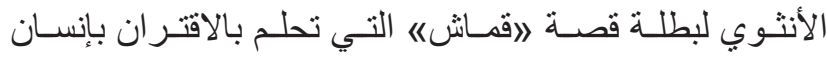

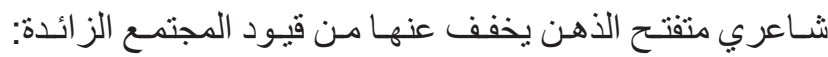
"حين دخلت الجامعـة صـار ماهر طرفة الأحاديـ الغراميـة

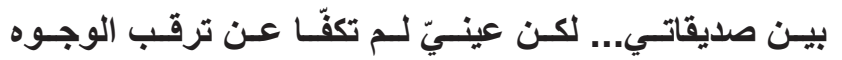

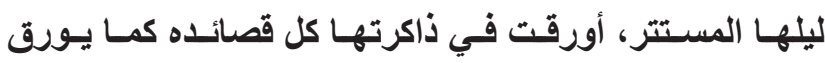

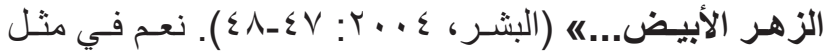

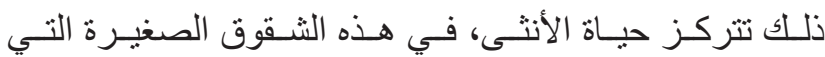
تتأبى على السـارد المذكر تتبعها والتي تكسـب سـرد الأنثى خصوصيـة.

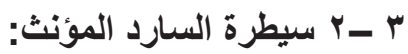

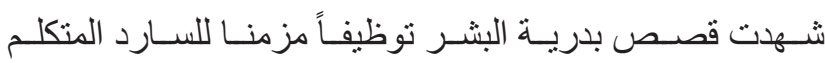

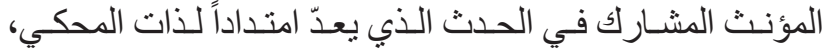

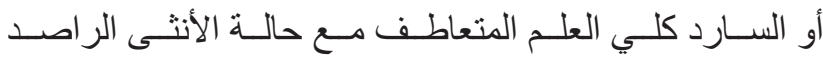

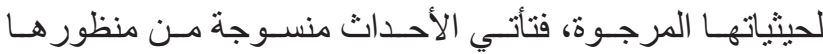

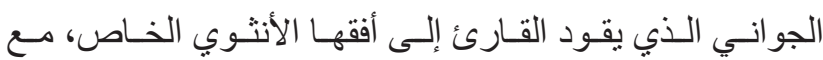

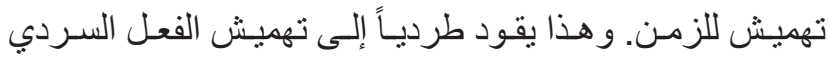
للاذكر ، إذ يغدو بعيداً عن صلاحياتـه المطلقة فهو المـروي عنها،

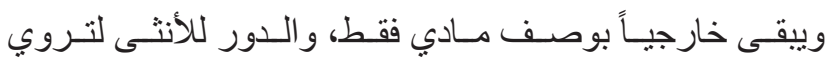

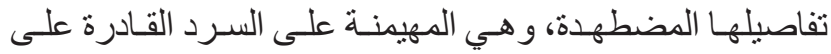

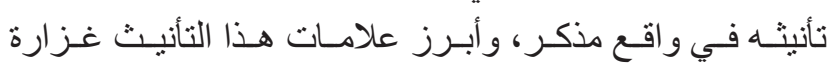

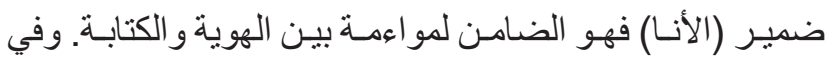

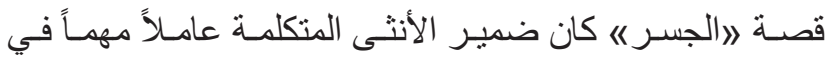

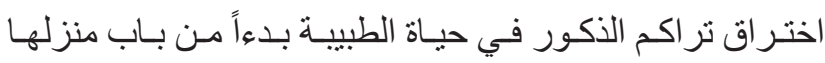
إلى المستشفى: االطريق إلى المستشفى بعيد... وعن جانبيه

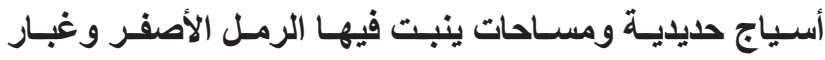

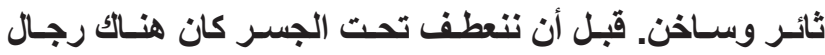

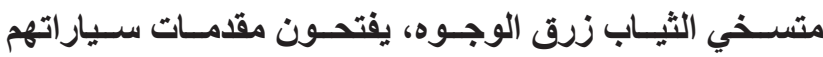

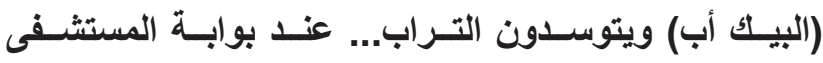

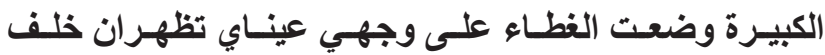

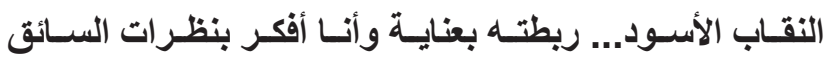
التـي ترصدنـي عبـر مـر آة السـيارة... أمسام مكتبـي أدخلـت

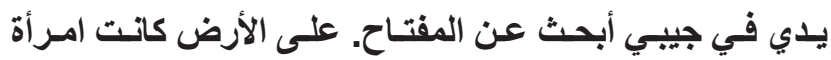

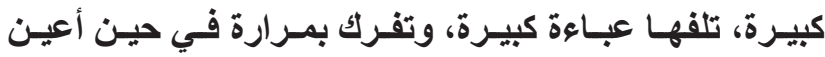

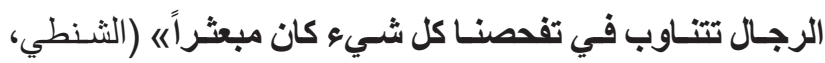

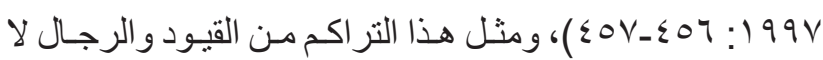

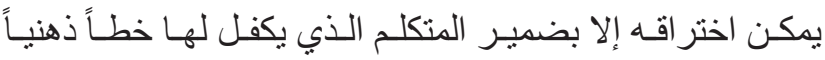

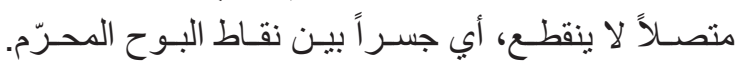

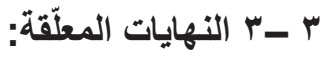

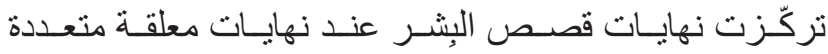

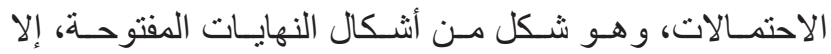

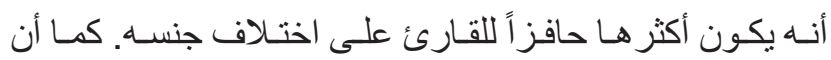
هذا الثـكل مـن النهايـات ينذر باستمر ار الإشـالية وتفاقمهـا،

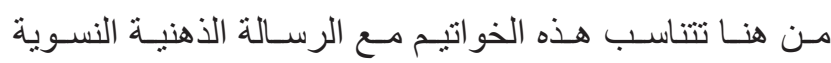

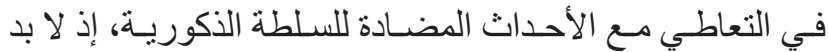


مناقثــة الظواهـر الاجتماعيـة ومـؤازرة بحسوث علمي الاجتماع

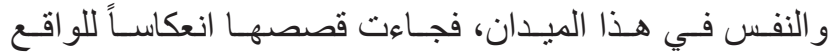
ومثيـرة للظو اهـر ورفعـاً لسـتار الكبـت التاريخـي والاجتماعـي

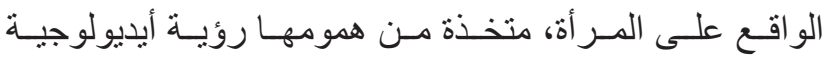
تحكـم خطابهـا التاريخـي القصصـي وتمــلأ قاموسـهـا اللغـوي، ولكن ضمـن تـوازن بيـن عالمهـا الأنثوي بوصفهـا كاتبـة وفنها القصصسي المؤطـر بالصــق.

حجـزت مسـاحة واسـعة فـي قصصهــا لتقصـي تمثيـلات الذكـورة المسـيطرة على المجتمـع فكثـفت سـلبية الرجل حيـال

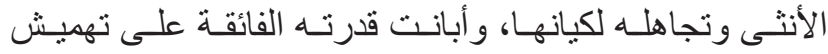

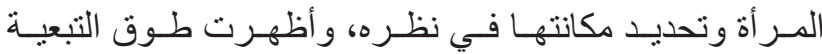

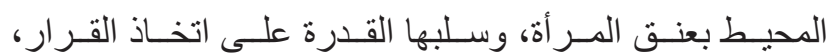

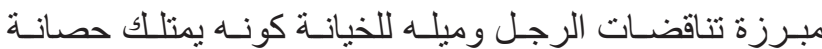

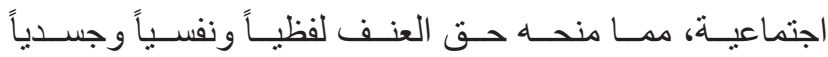

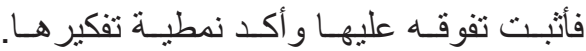

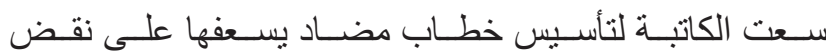
تمثيـلات الذكورة السـابقة، فاتخـذت مـن الكتابـة وسـيلة أنثويـة

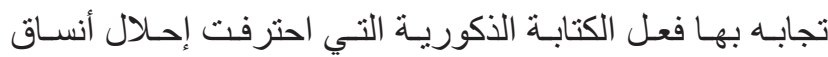

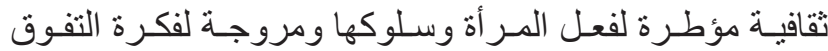

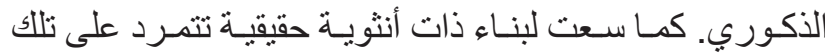

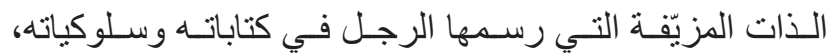
ورفعـت الكثيـر مـن شـخصياتها مـن مسـتوى الهامسش اليومسي

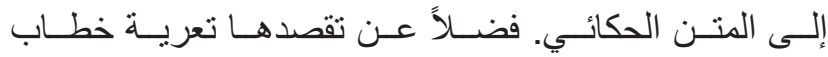

الأكـورة وكثـف تناقضـاتهـا وتهميشـهـ سـر دياً.

تقيّدت بدريــة البشـر في خطابهـا بملامـح أنثويـة للسـرد تعينهـا

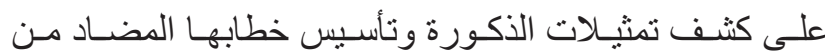

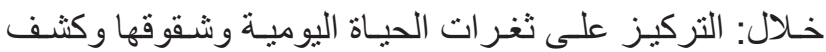
المسـكوت عنــه، والسـماح لثـخوصها بالبـوح و التداعـي

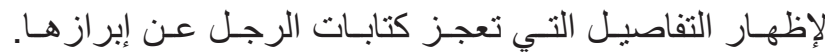

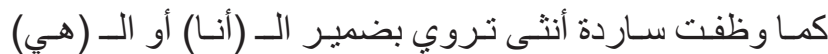

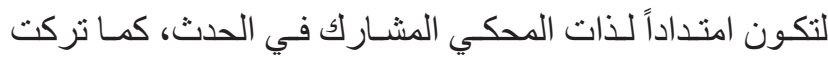

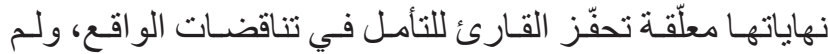
تثتـازل في ذلـك عـن اللغــة الثـعرية وقامسوس الجســـ الـذي يظهـر المعانـاة وقهر الأنتثى، بعيـداً عـن اللغــة الثـبقية. ويحسـب لبدريــة البثـر انشـغالها بقضيتهــا المركزيـة وطـر ح

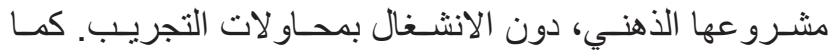

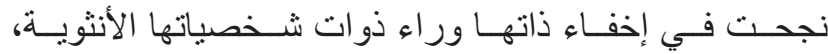

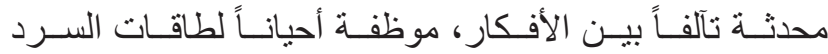

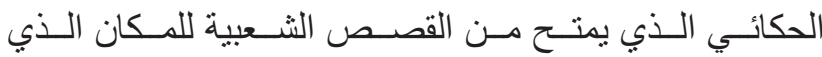

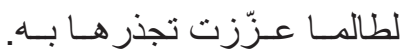

الشـمالية التـي تهـبّ مسن أماسـي القـراعة وأخبـار الأدبـاء. وفي صبـاح شـارد نحـو حلـم الشـمال كانـت الريـاض تشـتقبل ضيـوف مهرجانهـا الشـعبي الـذي تقيمسه كل عـام... عينـاي

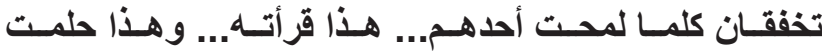
بـهـ... وهذا حفظت قصائـده... بنـات عمي قلن بعد كل هـا

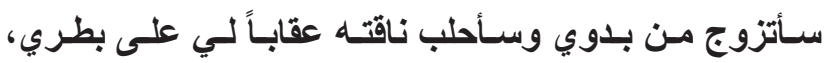

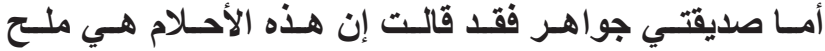

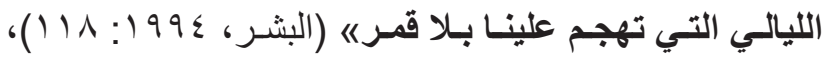

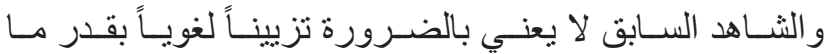
هـو بـوح عالـي المشـاعر ، وكثـف عـن ملـل في نفس البطلـة

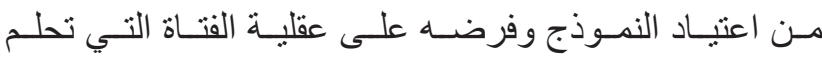
بالارتبـاط بمثقف يأتيهـا مسن الثـمال بشـبه ابـن الجيـران القديـم

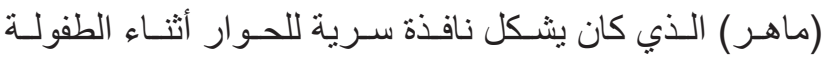
على أسـطح المنـازل المتلاصقـة، وهـي نافـذة وجهـت ذهنهـا

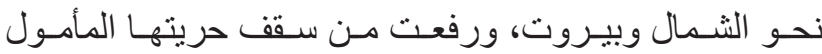
وتحررهـا نحــو الفعـل الثقافـي المتـزن الـذي يفجـر الطاقـات و المواهـب، وتتبــت هـذه الفكـرة في ذهنهـا وتكبـر حتـى بعـد

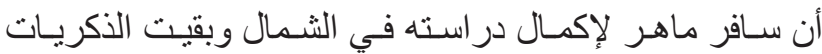

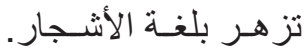

وتتعدد خصائص السـرد الأنثوي وتمتـد بأثنـكال أخرى مشكلة

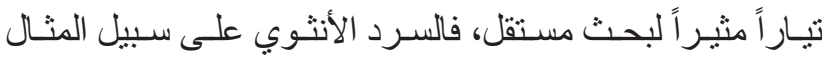

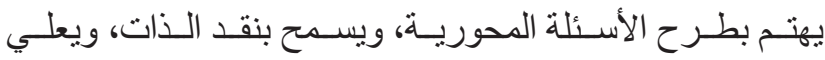

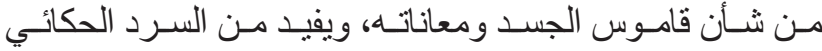

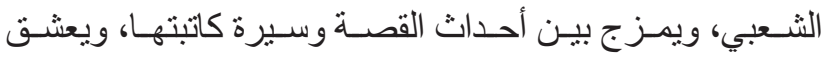

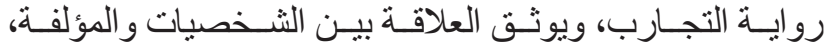

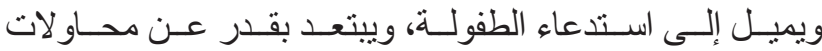
التجريب في الثكل، وكل ذللك يثكل انعكاسـاً تكاملياً مـع الرؤية التهاء

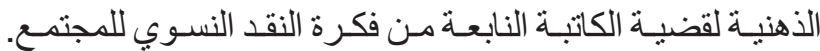

\section{الخاتمة}

وبعد، ووفق المنطلقـات المنهجيـة لهـذه الدر اسـة و المتخـذة مـن النقــ النسـوي رؤيسة لدر اسـة الخطـاب القصصـي لبدريـة البشـر

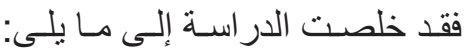

أظهر خطابهـا تفوقـاً في اسـتبطان عالم المـر أة الداخلـي مقابـل

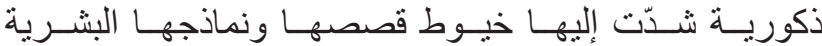

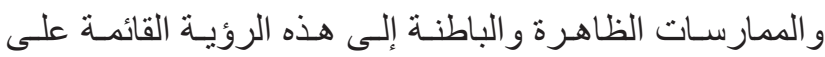

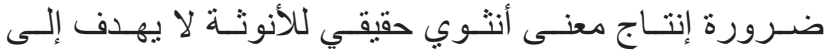

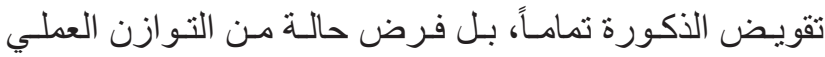

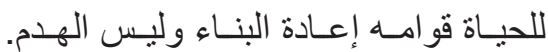
قدّمــت فـن القصــة القصيـرة بوصفـهـ شـكلاً أدبيـاً قــادراً على 


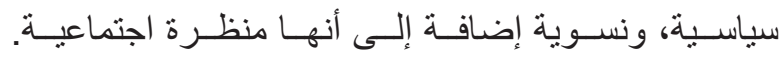

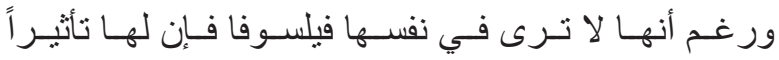

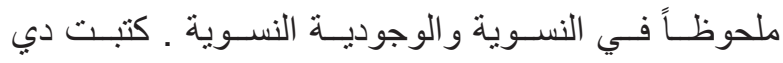

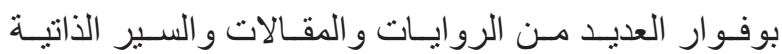

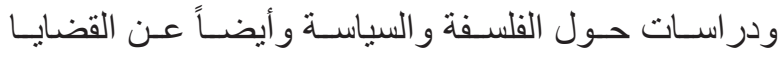

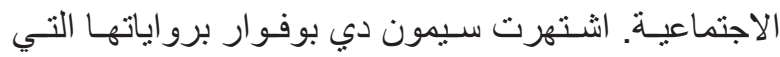

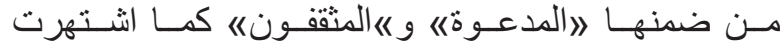

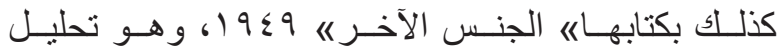

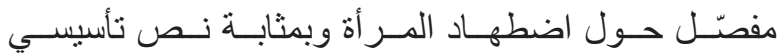
لللنسـوية المعاصــرة). عـ فكـرة الحواريـة فكـرة أطلقهـا ميخائيـل باختيـن في كتابـهـ

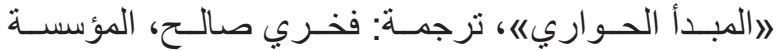

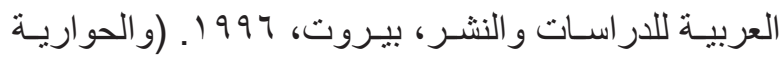

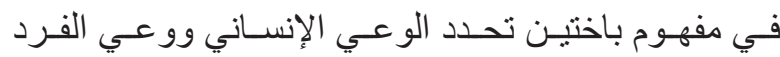

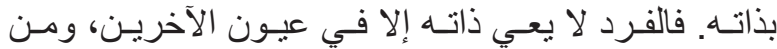

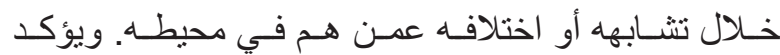

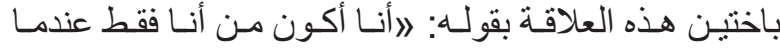

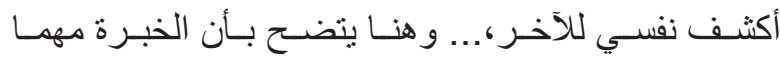

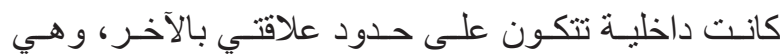

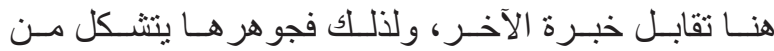

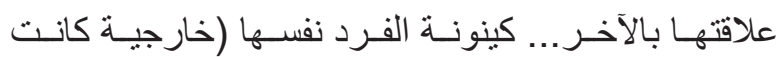

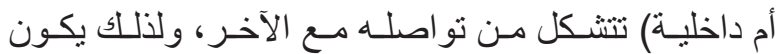

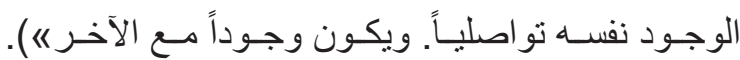

هـ تعـدّ فـــرة البطركيـة تعبيـراً قانونيــاً عـن وضعيـة أو

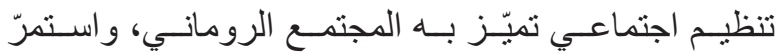

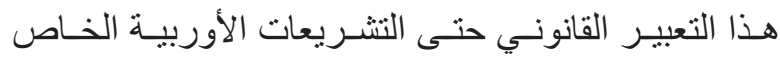
بالملكيــة و الإرث و والبـــوة.

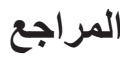

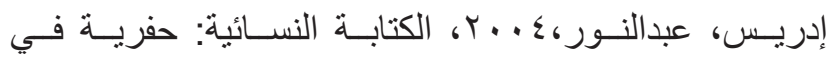
الأنســاق الدالـة، الأنوثــة/ الجســـ/ الهويسة، مطبعـة سجلماســة،

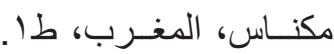

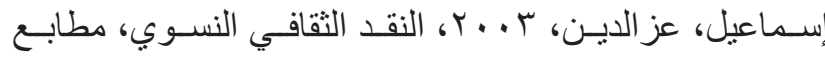

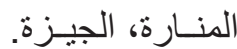

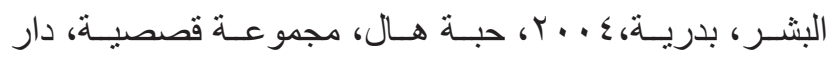

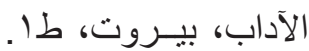

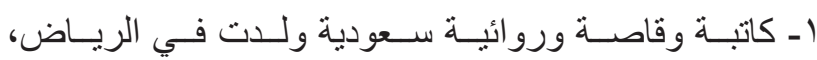

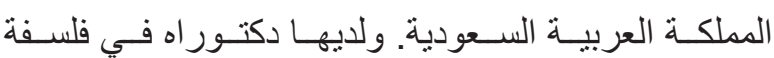
الآداب/ علـم اجتمــاع تخرجـت فـي الجامعـة الأميركيـة

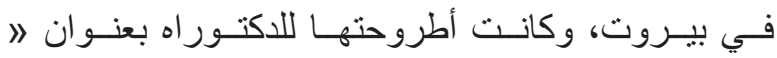

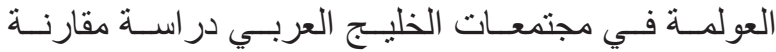

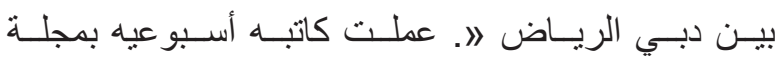

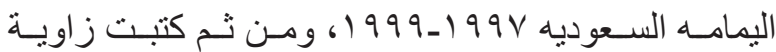

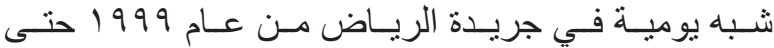

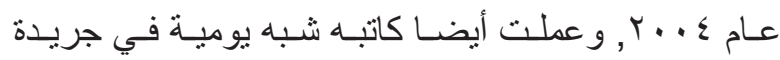

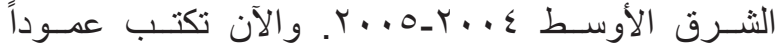

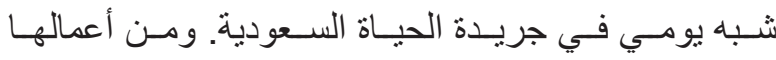

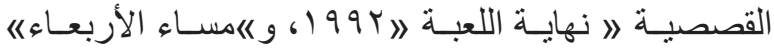

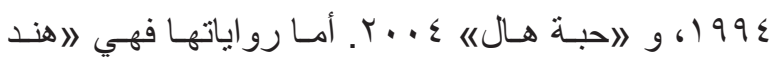

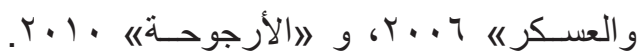

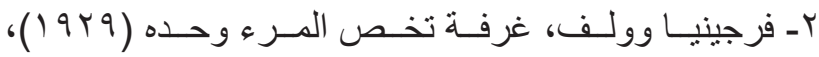

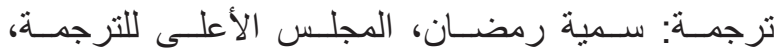

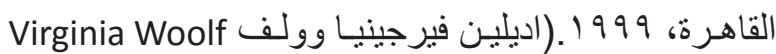

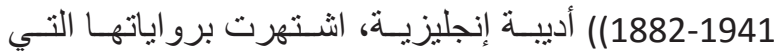

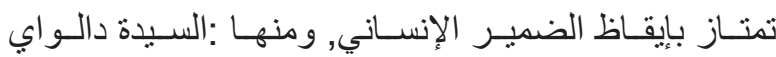

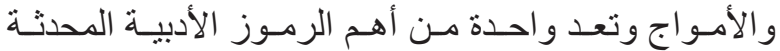

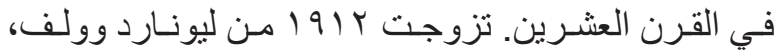

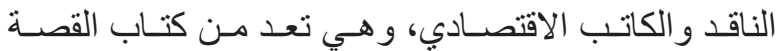

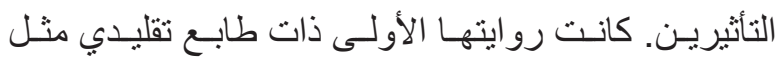

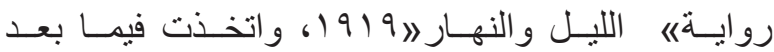

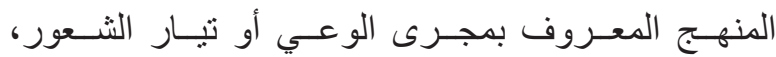

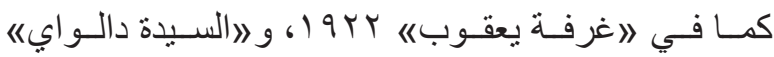

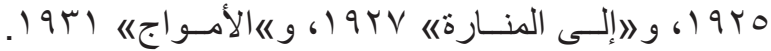

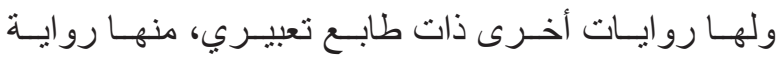

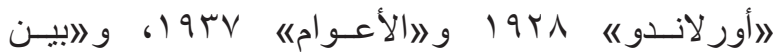

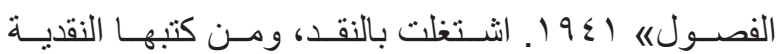

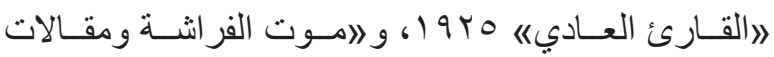

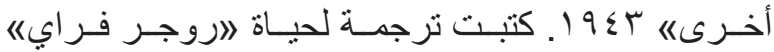

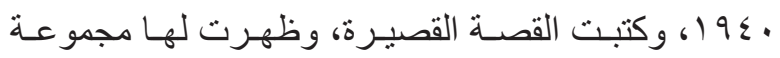

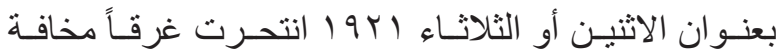
أن يصيبهـا انهيـار عقلـي).

r- سـيمون دي بفـوار: الجنس الآخـر (9 (19). سـيمون-

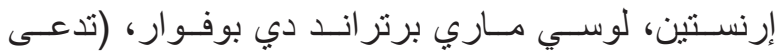
Simon de Beauvoir سيمون دي بوفـوار (1986-1908)

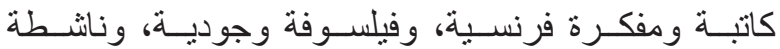




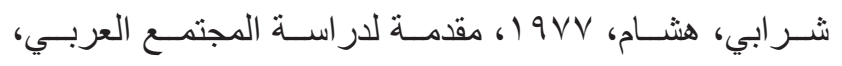

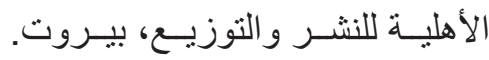

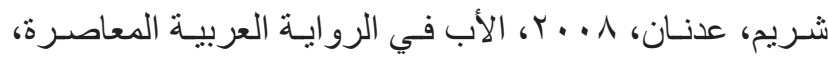

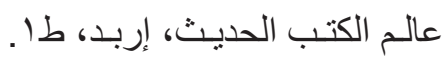

عبيـد، لينـدا، V. . . Y، تمثيـلات الأب فـي الروايـة النسـوية

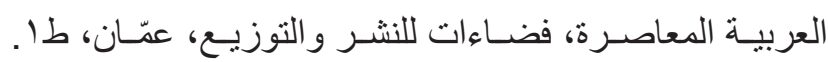
غذامـي، عبـدالله، 997 1، المــرأة واللغــة، المركـز الثقافـي

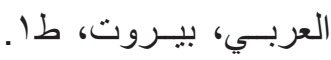

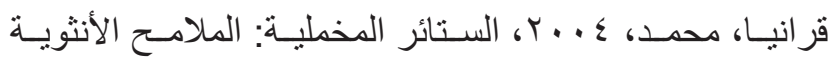

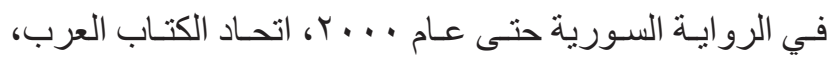
دمشتق.

معتصــم، محمــ، ع . . Y، المـر أة والسـرد، دار الثقافـة، الــار

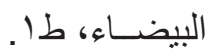

وولف، فرجينيـا، و 9 (1، غرفـة تخص المـرءو وحده، ترجمة: سمية رمضـان، 999 1، المجلس الأعلى للترجمـة، القاهرة.

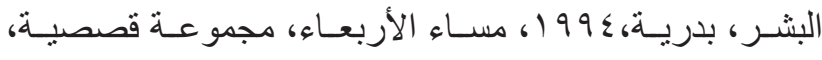

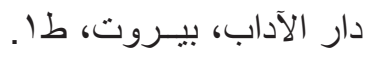

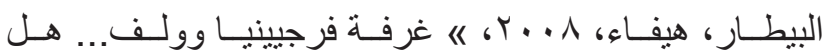

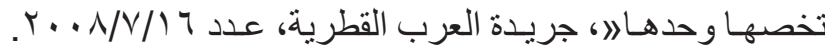

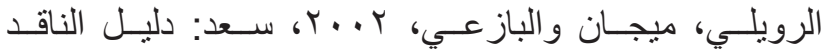
الأدبـي، المركـز الثقافـي العربـي، بيـروت، طب، طب،

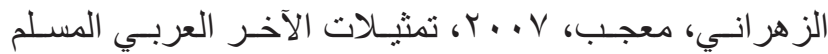

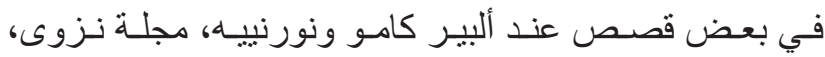

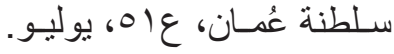

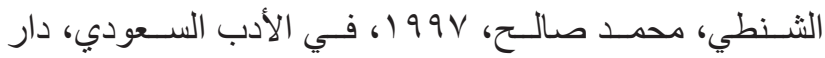

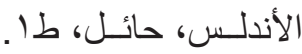

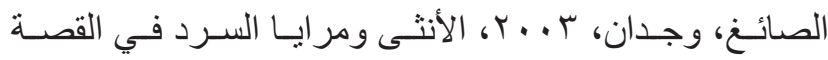

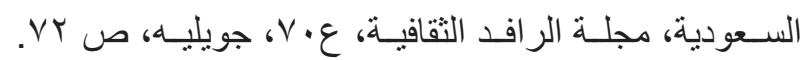

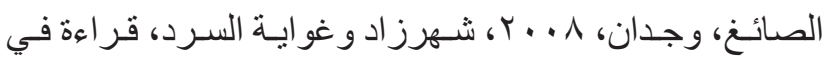

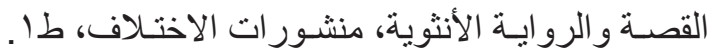

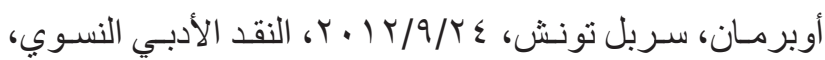

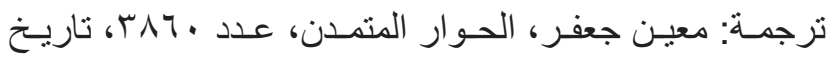

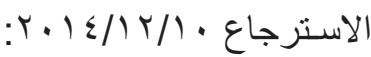
http://m.ahewar.org/s.asp?aid=325531\&r=0\&cid=0\&u=\&i=0\&q

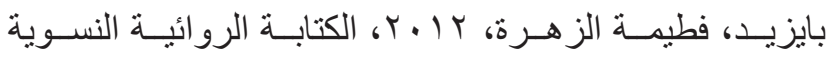

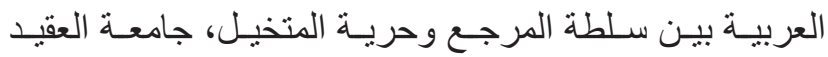
الحـاج لخضــر باتنــة، الجزائــر.

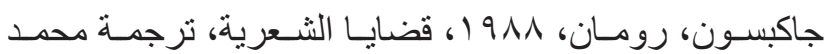
الولـي ومبـارك حنــون، دار توبقـال للنشـر، المغـرب.

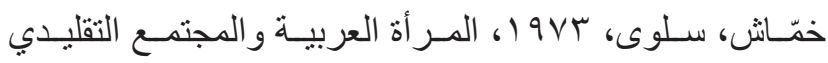

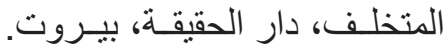

دي بفـوار، سـيمون، الجنس الآخـر، 9 9 19، ترجمــة: لجنــة

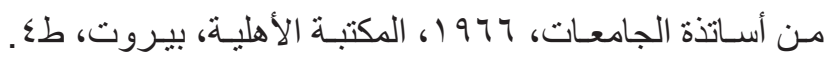

سـلان، رامـان، 910 1، النظريـة الأدبيـة المعاصـرة، ترجمـة: جابر عصفور، 991 1، دار قبـاء، القاهـرة. 